\title{
THE CONSTITUTIONAL CASE FOR THE IMPEACHABILITY OF FORMER FEDERAL OFFICIALS: AN ANALYSIS OF THE LAW, HISTORY, AND PRACTICE OF LATE IMPEACHMENT
}

\author{
BRIAN C. KALT
}

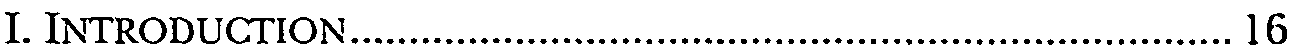

II. IMPEACHMENT BASICS AND THE SIMPLE ARGLMENTS FOR A.ND

AGAINST LATE IMPEACHMENT .................................... 18

III. HISTORY ..................................................................... 22

A. English Impeachment ........................................... 24

B. Pre-Constitutional American Impeachment ....................27

1. Colonial and State Cases................................. 27

2. State Constitutions ............................................. 29

3. The Articles of Confederation ........................... 39

C. The Framers and the Ratifiers................................... 40

1. The Convention ............................................... 40

a. Initial Proposals........................................... 41

b. Removing the President .................................... +3

c. The Hastings Paradigm.................................. 46

d. Late Adjustments......................................... 48

e. Conclusion.................................................. 49

2. Ratification ....................................................... 49

D. The Argument from History'...................................... 54

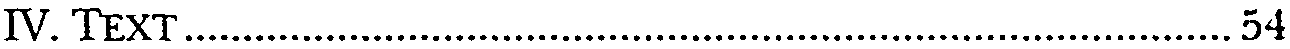

A. Everything but Article II, Section 4..................................55

B. Article II, Section 4....................................................58

1. The Over-Literal Reading: Helpful but Wrong.... 58

\footnotetext{
* Assistant Professor of Law, Michigan State Universitv-Detroit College of Law; A.B.. University of Michigan, 1994; J.D., Yale Law School, 1997. Thanks to Michatel Cerhurdt for his helpful comments and to Jorge Souss for his superbly incisse and helpful criticism. Special thanks to Chuck Ten Brink. Carol Parker and the rest of the outstanding library staff at MSU-DCL.
} 
2. The Expressio Unius Reading: Four Possible

Interpretations ..................................................

3. Conclusion ........................................................... 68

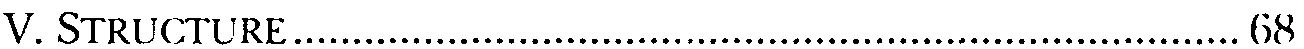

A. The Deterrent Effect of Impeachment.................................. 69

B. Removal, Disqualification, and Mootness .......................... 73

C. The Indistinguishable Stages of Impeachment.................... 75

D. Pardons, Presidential Removal, and the Impeachment as Inquest ...................................................................... 78

E. The Four Interpretations ................................................. 80

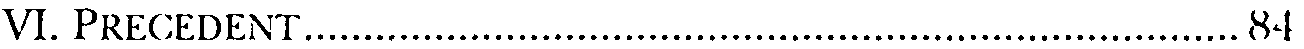

A. Federal Cases.................................................................

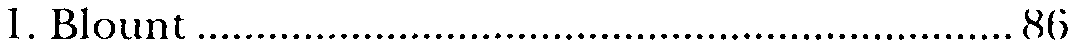

2. Calhoun and Webster ....................................... 89

3. Whittemore and Deweese ...................................... 92

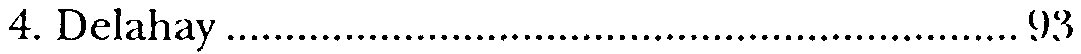

5. Belknap ............................................................. 94

6. Archbald ........................................................ 102

7. English ........................................................... 10 1)

8. Aborted Cases .......................................................... 106

B. State Impeachment After 1787 ..................................... 107

1. Post-1787 Changes to State Constitutions .......... 107

a. Georgia ........................................................... 108

b. Tracking the Federal Constitution ................... 112

2. State Cases ……................................................ 115

a. Early Cases..................................................... 115

b. Hill .......................................................... 116

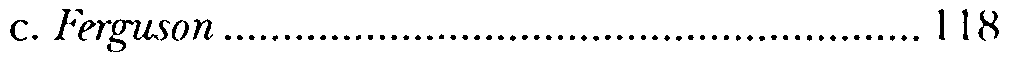

d. Smith .......................................................... 119

VII. THE COMMENTARY.......................................................... 122

A. Rawle and Story .......................................................... 122

B. Recent Commentary ..................................................... 123

VIII. PRACTICAL CONSIDERATIONS.......................................... 126

A. Disqualification ........................................................... 126

B. Punishment Beyond Disqualification ............................. 128

C. Precedent ...................................................................... 1.30 
No. 1 Law, History, and Practice of Late Impeachment

D. Timing....................................................................... 130

E. Congress Defends Its Turf ............................................ 131

F. Quick and Easy'........................................................... 132

G. Potential Abuse ................................................................. 133

H. Conclusion …............................................................... 134

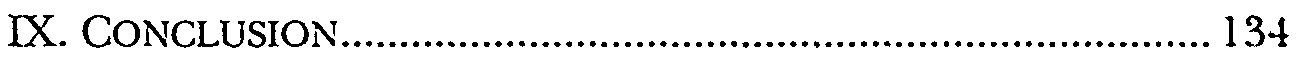




\section{INTRODUCTION}

Can federal officials be impeached even after they have left office? Or do the potential remedies of impeachment-removal, disqualification, and possibly others-disappear when an official leaves office? To put these questions in perspective, consider the following hypotheticals:

1. The Republican Party wins a series of stumning electoral victories and obtains the presidency and a two-thirds majority in both houses. The Party decides to deliver the coup de grâce and impeach all of the popular leaders of the oppositionmany of whom have just been narrowly voted out of office-in order to prevent them from fielding viable candidates in the next presidential election.'

2. A federal judge is about to be impeached for gross incompetence. Before the House can vote on the case, however, the judge resigns and flees the country. The House sees no practical reason to pursue the judge, but is wary of setting a precedent that impeachment may be stopped in its tracks on the whim of the offender. ${ }^{2}$

3. The Secretary of Defense is discovered to have been involved in a complicated bribery scheme during his carlier service in another federal post. He finds out that the llouse is going to impeach him, but he resigns hours before the vote and argues that he is now unimpeachable. The House wishes to proceed in order to disqualify him from federal office and take away his pension, to protect its jurisdiction, and to set a precedent that the Secretary's nuanced conduct in the bribery scandal constitutes an impeachable offense.'

1. This is an exaggerated version of the attempt by Jeffersonian Republic alls after the 1800 elections to remove holdover Federalist judges via impedchment. Ser EivII)

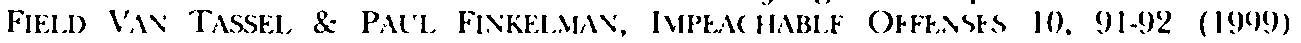
(describing Jeffersonian efforts); see also PETER (HARI.ES Hoffer \& . N.F.H. IIII. IMPEACHNEYT IX ANERICA, 1635-1805, at 151 (1984) (describing impeachment of Republican William Blount as "opening gambut" in Federalist plan to dispualify and thus "ward off potential [Republican] candidates"); see generally David P. (Curute. Thr Constutution in Congress: The Most Endangered Branch, 1801-1805, 33 W'Akr Fokfs1 1. RFv 219 (1998) (describing Jeffersonian assault on Federalist judges, particularly though we. of impeachment).

2. This is an adaptation of the common situation of federal fudges resgnung 10 aroid impeachment and the tension between the Iouse's reluctance to pursue oflenders and its concern for preserving its powers. See infra Part VI.A.7.

3. This is an adaptation of the case of Secretary of War Willam Belknap. In the actual case, however, Belknap's conduct was not particularly nuanced; it did not or c il in 
4. In the middle of the President's term, the Secretary of State is caught in a politically charged sting operation. The House impeaches the Secretary, and it is obvious that the Senate will convict. To help salvage the Secretary's political career (bigger comebacks have happened), the President fires him minutes before the Senate is to take its rote but denounces the "overzealous" Congress and appoints the exSecretary to be a personal advisor and emissany on foreign policy issues. The ex-Secretary argues that he cannot be convicted because he is no longer in office.'

All of these are examples of potential "late impeachments," an attempt by Congress to impeach and try a federal official after he has left office. There is no simple constitutional answer as to whether, in any or all of these scenarios, Congress can pursue a late impeachment. The text of the Constitution says nothing explicit about the timing of impeachment, neither expressly authorizing late impeachment nor ruling it out. Preconstitutional impeachment practices in England and America included late impeachment but are of uncertain applicability. The debates surrounding the framing and ratification of the Constitution provide fodder for debate but little clarification. Precedent from actual late impeachment cases is favorable to late impeachment but is ambiguous. Scholarly opinion, too, is generally favorable but divided. In short, though it has spurred heated and detailed debate, the question of late impeachability is close and unsettled.

Regardless of how close the question of late impeachment is, however, there can be only one answer." Either Congress can pursue late impeachments, or it cannot. The premise of this article is that Congress can pursue late impeachments, based on analysis of the text, structure, historical underpinnings, and precedent of the Constitution's impeachment provisions."

a different federal office; and his pension was not an issue in his impeachment tnal. be infra Part VI.A.5 (discussing Belknap case) and Part V'Il.B. (discussing pension wsue).

4. This is a very loose adaptation of the case of Texas Governor james ferguson, who resigned just before the judgment against him was pronounced and hus punshment approved. He was disqualified from future office, but his wife wits soon clected governor based in part on her promise that she would follow her husband's "adizce." Ser infra Part VI.B.2.c.

5. One can argue that late impeachment is constitutional in certam lumted cases. I reject that argument. See infra Part V.C.

6. This typology of constitutional argument is taken from Plilıp Bosstm. CONSTITUTIONAL FATE: THEORY OF THE CONSTITLTION (1982). Bubbul emumerates five different categories of constitutional interpretation: the four used here ("textual," 
Whether late impeachment should be pursued is a wholly separate question, and one that is easier to answer. ${ }^{7}$ In a pragmatic sense, Congress will rarely have a good reason (1) pursue late impeachment. Then again, it rarely has cause to pursue any impeachment. The impeachment power provides a significant incentive for federal officials to behave properly, and so the practical importance of late impeachment lies just as much in the offenses it prevents as in the ones it redresses.

In any case, if the Senate had ever been confronted with an ex-officer clearly worth convicting, it likely would have convicted and settled the question. It is possible, if not particularly common, for Congress to possess power that it chooses not (1) use. Late impeachment may prove practical and worthwhile in the future if the offense is heinous enough, if the stakes are raised high enough, or if the offender is situated just so. Even if it is not worthwhile, there may be enough members of Congress who believe otherwise to force the issue. Because such a case would be highly charged, both politically and emotionally, it is better to hold this constitutional debate now, with cooler heads and purely hypothetical defendants."

\section{IMPEACHMENT BASICS AND THE SIMPIE ARG(MMENTS F(OR AND) AGAINST LATE IMPEACHMENT}

The Constitution gives the House of Representatives the sole power to impeach ${ }^{9}$ and the Senate the sole power to try impeachments, with a two-thirds majority required to convict."

"historical," "structural," and "doctrinal") and "prudential" interpretation. It. at 7. Ihw article does not make a prudential argument because such arguments are "uctulted by the political and economic circumstances surrounding the decision" by the pruclentalist decision-maker. Id. at 61 . Because this article is an effort to argue in the abstlact, lhe'se are no applicable "circumstances" to discuss. Sep infra note 8 . Some pratil al considerations are discussed in Part VIII, infra.

Bobbitt suggests, somewhat tentatively, adding a sixth mode to the canoul the "ethical" argument that derives decisions from the ethos of the Anerican polity Sir" BOBвITT, supra, at 93-94. Given the uncertain status of this mode in the canon, it is not treated separately here.

7. See infra Part VIII.

8. It is worth stating near the outset that this article is not about impeachung ans particular ex-official. I have argued elsewhere that a late impeachment of Piesicleit Clinton is possible, but those arguments are now largely moot, and. anvwav. weve primarily concerned with abstract constitutional principles. Sep Bran Kilt. “ Ind Sa) Out!": The Constitutional Case for Post-Presidental Impeachment, J('RISI (Mar. 1. 2001), at http://jurist.law.pitt.edu/pardonop3.htm; Brian Kalt, And Stay Ont: Impeachment Should Remain on the Table for Clinton, NAT'L POSI (Toronto). June 9, 1999. at Al4.

9. See U.S. CONST. art. I, \$2, cl. 5.

10. See ad. $\$ 3, \mathrm{cl} .6$. 
When the President is on trial in the Senate, the Chief Justice presides." The "judgment" (i.e., sentence) in an impeachment case cannot "extend further than to removal from Office, and disqualification to hold and enjoy any Office of honor, Trust, or Profit under the United States."' The President cannot use his pardon power to prevent, preempt, or undo an impeachment," but once impeached and convicted, a person is still subject to the regular criminal process. ${ }^{14}$

The most important constitutional clause concerning late impeachability is Article II, Section 4, which states: "The President, Vice President and all civil Officers of the United States, shall be removed from Office on Impeachment for, and Conviction of, Treason, Bribery, or other high Crimes and Misdemeanors." 15

Those who believe that late impeachment is unconstitutional rely very heavily upon this clause.$^{16}$ First of all, they say the clause provides for impeaching only " $\mathrm{t}] \mathrm{he}$ President, Vice President, and all civil officers." "Officer" means "officer," not "ex-officer. ${ }^{\text {"1: }}$

11. Id.

12. Id. cl. 7. In my own view, this disqualification does not affect the commet's abilus to serve in Congress, because the Constitution uses the term "office" exclisstels of serving in Congress. See, e.g., id. $\$ 6, \mathrm{cl}$. 2 ("[N]o Person holding anv oflice under the United States, shall be a Member of either House [of Congress] during his (ontunuance in Office."); id. art. II, $\$ 1$, cl. 2 (“[N]o Senator or Representative, or Person holding an Office of Trust or Profit under the United States, shall be appointed an Electur.") (emphasis added). But others are not so sure-Judge Alcee llastings wis impearched. convicted, but not disqualified; when he was elected to Congress, some speculated that

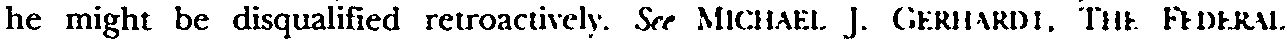
IMPEACHMENT PROCESS 60-61 (2d ed. 2000).

13. See U.S. CoNSr. art. II, \$2, cl. 1: Brian C. Kalt, Note. Parden .Me?: The Constitutional Case Against Presidential Self-Pardons. 106 Yil. 1.J. 779.78586 (1996) (explaining broad interpretation of impeachment exception to pardon power).

14. See U.S. CoNST. art. I, \$ 3, cl. 7.

15. Id. at art. II, $\S 4$.

16. Those who have written against late impeachabilitw unclude Justuce Joreph Ston. see infra Part VILA; a significant minority in the Senate, see infre Part li...: and

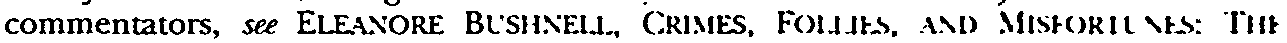
Federal IMPEAChMent TrIals 16 (1992); Robert C. Stelle. Note, Defimmg high (inmes and Misdemeanors: A Call for Stare Decisis. 15 J.L. \& POl.. 309. 358 (1999) (menuomug "rule" that "former federal officers [can] not be impeached"): Jorye E. Souss, Impeach Clinton? Why Not Impeach O.J.?. Jerisr (Mar. 1. 2001), at http://juristlaw.pittedu/pardonop4.htm. Hoffer and Hull seem to assume that late impeachment is inappropriate as well. See HOFFER \& Ht H., supra note 1. .t 257 (regarding Blount case as federal precedent against late impe:achabilitv).

17. Throughout this article, the term "civil officers" will be used as at catch-all including not just federal civil officers but also the President and Vice President. Technically this may be incorrect, as the Constitution distungushes the Prestent and Vice President from civil officers. Article II. $\$ 4$ does not sal "all other cull officen," after all. The distinction appears to be that the President and Vice President are clected, sex 
As one lawyer, speaking in the midst of an actual late impeachment, put it: "A half-grown boy reads in a newspaper that the President occupies the White House, if he would understand from that that all Ex-Presidents are in it together he would be considered a very unpromising lad."

The second part of the classic argument against late impeachment is based on punishment. There is no way to "remove[]" an ex-officer "from Office" as these critics say Article II, Section 4 requires." If Article II, Section 4 applies to exofficers, they contend, then its removal provision makes no sense-not a conclusion about the Constitution and its Framers that one should make lightly. ${ }^{20}$ In a broader sense, some critics have argued, impeachment is not about punishing individuals anyway; it is about protecting the office from bad occupants. ${ }^{21}$ Under this theory, once an offender is out of office-by whatever means-no proper purpose for impeachment remains. ${ }^{22}$

The third part of the argument, a reductio ad absurdum logically derived from the first two, is that any interpretation of Article II, Section 4 permitting late impeachment must permit any impeachment. To these critics, the only interpretive choices are either limiting impeachment to sitting officeholders or

U.S. CONST . art. II, $\$ 1, \mathrm{cl} .1$, while civil officers of the U nited States are commissoned by the President, see id. \$3. On the other hand, the Constitution refers repeatedly to the President and Vice President as holding "office." Sep, e.g.. ul. at art. I. \$3. cl. 5: w. at at II, $\$ 1$, cl. $1,5,8$; id. at amend. XII.

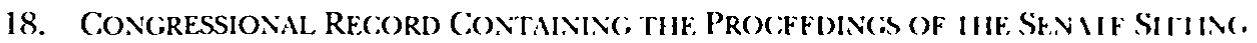
FOR THE TRIAL, OF WILLIAM W. BELKNAP, IAIF SECRETARY OF WAR 71 (GoveInmen! Printing Office, Washington 1876) (hereinafter BELKNAP TRIAL) (atgument of defense counsel); accord Souss, supra note 16 ("The word 'President' appears 14 other umes an Article II, and in every single case it is undisputed that it refers to the person serving as President, not to a former President."); BEL.K.W.TP TRLLL, supra, at 132 (opmion of Sendton Boutwell); of. id. at 40 (recording absurdum suggestion by detense counsel itI late impeachment case that trials of former presidents would have to be presided oves by chief justices).

19. This leaves open the question of what to do with someone who has left one federal office but who is currently holding another. Should such a person-who in all officer, after all-be susceptible to impeachment for offense's committed in his prevous office? See infra Part V.E. (discussing different models of impeachability and tueatment of offenses in former offices).

20. See. e.g., infra note 355 and accompanying text (Belkndp (ase); $m / m$ tat accompanying note 499 (Justice Story); Souss, supra note 16.

21. See. e.g., Jonathan Turley, "From Pillar to Post": The Proseculoon of Amrnan Presidents, 37 AN. CRIM. L. Rev. 1049, 1052 (2000) ("Impeachment serve's a distunct, nonpunitive function. The Impeachment Clause is designed to protect the office of the presidency ....").

22. See. e.g., infra text accompanying notes 500)-01. 
ignoring the mention of "officers" and "remov[al]" and extending impeachment to all manner of private citizens. In other words, they see no principled constitutional basis to distinguish between private citizens who used to hold office and those who did not. ${ }^{23}$

That, in short, is the simple argument against late impeachment. (The complicated argument against late impeachment consists of various rebuttals to the argument in favor of late impeachment, and thus will emerge in pieces in the remainder of this article.) Unsurprisingly, given the closeness of this question, the argument against late impeachment is not unreasonable, and it has attracted significant historical and scholarly support. ${ }^{24}$ Nevertheless, it also has problems-textual, structural, historical, and precedential-that in the end tip the constitutional scales against it.

The argument for late impeachment is, relatively speaking, not as simple. It has several parts, each of which will be developed in its own Part of this article. A brief summary before embarking is useful. Textually, the Constitution does not address the appropriate timing of impeachments, and those readings that suggest it does are flawed. ${ }^{25}$ Structurally, late impeachment provides a more coherent and sensible framework for the timing of impeachment. Barring late impeachment would weaken the deterrent effect of impeachment and would allow malfeasors and Presidents to nullify Congress's impeachment powers in a way that is incompatible with the Constitution's structure." Historically, late impeachment was practiced before (and during) the drafting of the Constitution, but unlike other questionable aspects of impeachment, it was not criticized in the pre-constitutional era or explicitly trimmed back in the final document. $^{27}$ Finally, doctrinally, there is subsequent precedential support for late impeachment, not the least of

23. See, e.g., Souss, supra note 16 ("Instead of impeaching the former President, whs, not impeach acquitted murderer O.J. Simpson, whose personal approval ratings are eren lower than Mr. Clinton's? Ridiculous, you say? Well, not quite, if we use the sime flawed logic being disseminated by those who claim that a former officer of the Linited States is subject to impeachment."); infra note 356 and accompanying text (Belknap case).

24. See, e.g., infra Part V.A (historical support); notes 496-501. 511-12, 518, and accompanying text (scholarly support).

25. See infra Part IV.

26. See infra Part V.

27. See infra Part III. 
which is the fact that the Senate once ruled specifically that it had jurisdiction over a late impeachment trial. ${ }^{2 *}$

None of these arguments, alone or together, can conclusively prove that late impeachment is constitutional. The arguments in favor of late impeachment have caveats and flaws. Remember, this is a close constitutional case. Nevertheless, the constitutional case for late impeachment has more strengths and fewer flaws than the case against it.

\section{HISTORY}

While it is ordinarily proper to begin a constitutional argument with text and structure, in this case it is uscful to begin with history. The history of impeachment practice will shed light on the meaning of the word "impeachment," which is important for textual understanding. Specifically, preconstitutional history demonstrates that impeachment is limited to public offenses and offenders, refuting the concern that allowing late impeachment would mean allowing the impeachment of any private citizen. This history also sheds light on the structure of constitutional impeachment, which is important for structural understanding. History shows the importance of the deterrent effect of impeachment, of which late impeachment is an important structural component. At the same time, history also provides independent evidence-it reveals that allowing late impeachment is feasible, desirable, and precedented.

\section{A. English Impeachment}

English impeachment is the ultimate foundation of American impeachment. ${ }^{x_{1}}$ To be sure, American impeachment in 1787 was also influenced by colonial and state experiences," but English impeachment informed those colonial and state experiences,

28. See infra Part VI.

29. See THE FEdERulist No. 65, at 397 (Alexander Hamilton) (Clinton Rosster ed . 1961) (referring to British impeachment as "It]he model from which the idlea of the institution [American impeachment] has been borrowed"); see also RMOII BtR(.tR.

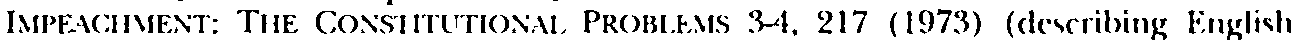
influences on American impeachment); GORDON S. WOOD, (XRENIION OF III AMt RIC WN RFPL BLIC: 1776-1787, at 141 (1969) (describing English Whig roots of Ament.u impeachment).

30. See HOFFER \& Hetl., supra note 1, at 268 (anguing that colonial and state impeachment precedents "were far more important in influencing fecleral law that" English examples"). 
and it further provided parallel precedents for the federal Framers to consider.

Impeachment was practiced in England sporadically from the fourteenth century to the early nineteenth century." The last significant burst of activity occurred in the seventeenth and early eighteenth centuries; impeachments slowed to a trickle by the 1720 s and cease to be discussed after 1806."

In essence, English impeachment was a criminal prosecution that began in the House of Commons instead of before a grand jury and that was tried before the House of Lords instead of the criminal courts. Because of this unique structure, it was directed particularly at public officials and public offenses.

Initiating prosecution in the House of Commons rather than through a regular grand jury was not unique to impeachment; there was also the bill of attainder, in which Parliament would pass ad hoc legislation to punish an offender. Because a bill of attainder was a legislative act, however, it required the approval of both Parliament and the King." By contrast, impeachment was a judicial process in which the House of Lords had the last word and the King had no voice. Impeachment was also less ad hoc and developed its own common law of sorts."

As impeachment did not require royal approval, it became a popular mechanism in the seventeenth century for Parliament to control the King's high officers." Parliament could not control the King directly-other than extra-legally-but it could impeach and convict his subordinates. Parliament's struggle to assert its authority over the King through impeachment came to a head in 1679. In that year, King Charles II pardoned the Earl of Danby in order to preempt Parliament's investigation of the King's questionable dealings; Parliament responded shordy thereafter by limiting the pardon power to prevent such preemptive strikes in the future. ${ }^{36}$ However, the rise of the

31. See BERGER, supra note 29, at 1-3 (summarizing English umpeachunent hston).

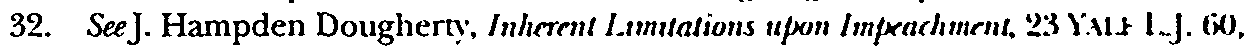
$68-69$ (1913) (giving chronological breakdown of English impeachments).

33. See BERGER, supra note 29 , at 28 (discussing attainder and requirement of roval assent).

34. See 4 Willam Blackstone, Commentaries *259 (stating that while altanders are new laws, "an impeachment before the lords by the commons of (ireal Britan, in parliament, is a prosecution of the already known and established law").

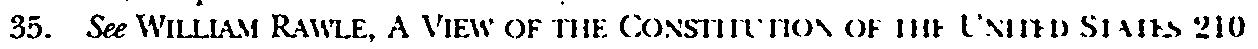
(Da Capo Press 1970) (2d ed. 1829) (discussing impeachment and lach of reval control).

36. See infra text accompanying notes $258-260$. 
parliamentary impeachment power signaled a corresponding weakening in the independent power of the Crown and thus, paradoxically, a decline in the need for impeachment. Once Parliament had cemented its control, and once the cabinet became responsible to the government rather than the King, there was much less reason to impeach anybody. ${ }^{37}$

Even though reining in the King's ministers was the most significant use of impeachment, Parliament could and did impeach private citizens. English impeachment was not technically limited to public offenses or public offenders. Anyone (except the royal family) could be impeached, in essence because Parliament could do whatever it wanted (except to the royal family). ${ }^{38}$ By the time of Blackstone in the micl1700 s, however, the well settled rule was that a commoner could only be impeached for "high" offenses (i.e., those against the state) and that only peers could be impeached for both public and private offenses.

The impeachment of peers for private misconduct was based on the fact that the ordinary courts were not equipped to try such significant defendants-peers required, quite literally, a jury of their peers." As for the impeachment of commoners, the limitation of parliamentary jurisdiction to public offenses wass significant. One must remember that Britain does not separate its powers; impeachment trials were held before a judicial body-the House of Lords-that sat as a court in other sorts of cases as well." What made impeachment cases special was that the prosecution was directed by the House of Commons, the "grand inquest" of the nation for offenses against the state. ${ }^{12}$ For

37. See HOFFER \& Ht'L, supra note 1 , at 28 (describing rise and fall of umpeachment in England); see also Theodore W. Dwight, Tral by Impeachment, 6 AN. L. RF (. 257, 282 (new series) (1867) ("There is no poltical reason for impeachment at the present ume. as the power of the Commons is never resisted by a minister or the Executive. In lact. It may be said in a representative government, that the absolute cessation of mpeachumens indicates that the legislative department has triumphed over the executse and he agents.").

38. HOFFER \& HCLL, supra note 1, at 4 ("[T] he Commons could impeach anyone m the realm except, perhaps, the royal family.").

39. See 4 BLACKSTONE, supra note 34 , at *259-60. Blackstone mentuoned that commoners could not be impeached for capital offenses but provided a counter example involving an impeachment for high treason. $I d$. at *260 n.2.

40. See id. at $* 260-61$.

41. HOFFER \& HLLL, supra note 1 , at 3 (describing judicial role of House of lorks. which continues to this day).

42. E.g, 4 Bl-AckstoNe, supra note 34 , at *259 (defining impeachment a presentment to the most high and supreme court of criminal jursdiction by the most 
mere offenses against the peace by mere commoners, the regular judicial process was adequate.

For reasons of national institutional suructure, then, impeachment was used to prosecute public offenders or public offenses, cases that "the ordinary magistrate either dare[d] not or [could] not punish."

By 1787, English impeachment had further narrowed in scope. For over a century, "impeachment [had] c[o]me to stand for a justifiable concern among the Commons for misconduct in high places." ${ }^{n 4}$ The last (and anomalous) impeachment of a common private citizen was that of Doctor Sacheverell in 1709 for sedition. ${ }^{45}$ Even before Sacheverell, virtually all cases involved either treason by peers or, more commonly, mismanagement by government officials. ${ }^{46}$ To the extent that impeachment had been used in the memory of anyone living in 1787 , then, it was for cases of public offenses by public figures."

Late impeachment was never a disputed issue in England. Initially, the bounds of impeachment were largely unlimited, and timing was no exception. Late impeachment was only an

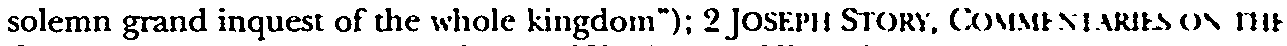
CONSTITUTION OF THE UNITED STATES 237 (Boston, Hilliard, Gray, \& (o). 1833) (quuoung Blackstone's successor Wooddeson that Parliament and not "ordman tribundis" are equipped to deal with "political" offenses). The "grand incquest" language recurs in discussions of impeachment. See, e.g., infra note 276 and text accompamving notes $85,87$. and 302.

43. 4 BLACKSTONE, supra note 34, at *260-61. Blachstone was speahung here onls of

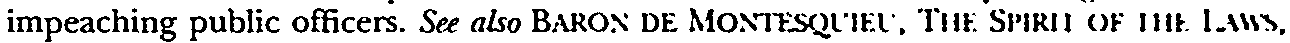
book 11, ch. 6, at 159 (Thomas Nugent trans., Hafner Publishing (ompam 19.49) (17.48) ("It might also happen that a subject intrusted with the administration of public affars may infringe the rights of the people, and be guilty of crimes which the ordinan magistrates either could not or would not punish."). Justice (and Framer) James Wilson made the same point in his famous Lextures on Lau in 1791. Sere I THE. llokhs (OF J.14ts WILSON 426 (Robert Green McCloskey ed., 1967), aratlable at hup: presspubs.uchicago.edu/founders/documents/al_2_5s15.html ("lic find the commons appearing as the grand inquest of the nation, about the latter end of the reign of Fedward the third. They then began to exhibit accusations for crimes and msedemeanon, angumst offenders who were thought to be out of the reach of the ordinan power of the law.").

44. HOFFER \& HULL, supra note 1, at 6 (characterizing English impeachment from 1650 s onward).

45. See id. at 4 (describing Sachererell case).

46. See id. at 8 (describing two "well-defined" categones mo whoh all impeachments fell after early 1700s).

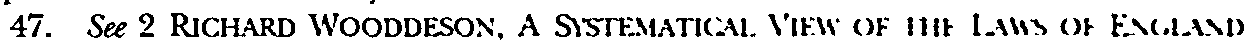
*601 (London, Payne 1792) ("All the king's subjects are impeachable in parlatment . Such kinds of misdeeds however as peculiarly injure the commonwealth bv the abuse of high offices of trust, are the most proper. and hate been the most usual grounds for this kind of prosecution."); BELkNAP TRIAl., supra note 18, at 109 (opmun of Senator Mitchell) (making similar historical point and anguing that American mpeachment incorporated English impeachment as it existed in 1787, not 1376). 
issue if the defendant was an officeholder. Additionally, punishments upon conviction in an impeachment court were severe-loss of property and even death were not uncommon ${ }^{18}$ - and so punishment in impeachment cases was not mooted if the target left office." But late impeachment remained as a sensible option even as impeachment became more focused on public offenses by public officials, and the punishments became more restrained. ${ }^{\text {no }}$ Impeachment was morc about creating a culture of accountability than it was about removing bad men from office, which could be accomplished by other means anyway, and late impeachment exemplified this fact."

Lord Chancellor Macclesfield was impeached and convicted for bribery in 1725, after he had left office." After that, no public officers were impeached" until 1786, when impeachmont proceedings began against Warren Hastings, the first (overnorGeneral of India, for his conduct in that post." Like Macclesfield, Hastings had already left office," but this fact wats not an issue-accountability was. After several articles of impeachment against Hastings were approved over a period of more than a year, the House of Commons impeached Hastings on April 3, 1787," shortly before the constitutional convention began in Philadelphia on May 25th. The trial in the House of

48. See Hoffer \& He L., supra note l, at 3 (describing English impeatument punishments).

49. (f. infra Part V.B (discussing disqualification in American impeachment).

50. Lord (hancellor Macclesfield, for instance, was removed from office (not the

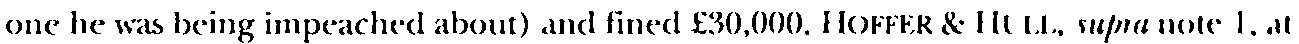
8 (describing. Macclesfield case).

51. (\% infra part V.A (discussing accountablity and cleterrent eflect of impeachment).

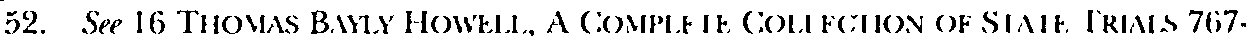
68 (London, T.C.. Hansard 1816).

53. The only other case in the interim was that of Jacobite conspuator Lomd lan.at. who was impeached, convicted, and executed for high treason in 1716 . He was a peer.

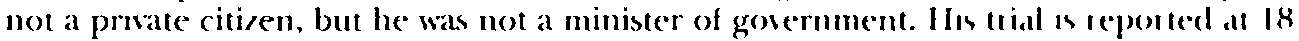
HowELL, supma note 52, at 529-858.

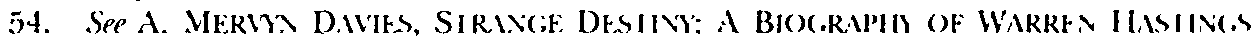
$373-74$ (1935) (discussing instigation of impeachment proceedings against llastungs by Edmund Burhe). Davies"s book is unabashedly pro-tastings but relates the chonologs of events clearly. See infra Part III.C.1.c (discussing the American Framess vews on the Hastings case).

55. Hastings had resigned his post in 1785. See Dav's s, supra note 54 , at 33.1-35).

56. See ad. at 383; see also ad. at $377-83$ (discussing impeachment proceedings 11 House of (ommons). 
Lords proceeded sporadically, until 1795, when Hastings was acquitted. $^{57}$

After Hastings, there was only one other impeachment in English history, and it too was a late impeachment. In 1806, Lord Melville was impeached for acts committed in an office he had held decades earlier; like Hastings, Melville was acquitted but not due to any suggestion that the impeachment was untimely. ${ }^{58}$

To summarize, by 1787 English impeachment was understood as being directed against public offenses by public offenders, for which Parliament was the proper venue for prosecution. The goal of impeachment was public accountability, not simply punishment. Late impeachments, such as those against Macclesfield, Hastings, and Melville, were thus perfectly appropriate. $^{59}$

\section{B. Pre-Constitutional American Impeachment}

In the eighteenth century, impeachments were relatively common in the colonies, and later in the states. Peter Charles Hoffer and N.E.H. Hull have argued convincingly that American impeachment practice was deeply rooted and widely practiced, and it developed its own characteristics independenty of the (comparatively fewer) contemporary English cases." Moreover, the impeachment power in the states was generally rooted in textual authorization from the states' constitutions. The colonial and state experiences with impeachment thus directly informed the federal constitutional impeachment power. Although late impeachment was less firmly established in pre-constitutional America than it was in England, it was known and accepted.

\section{Colonial and State Cases}

Among the defining characteristics of impeachment on this side of the Atlantic was its uniformly public character: Even

57. See id. at 411-12 (recounting Hastings's acquittal).

58. See BELKNAP TRLAL, supra note 18, at 54 (discussing Melville cabe dunng an American late impeachment trial). The lengthy Melille case is reported in 29 Howk1. supra note 52 , at 549-1482.

59. See BELKNAP TRLAL, supra note 18, at 363 (opinion of Senator Nomood) (cutung Macclesfield, Hastings, and Melville precedents).

60. See HOFFER \& HULL, supra note 1, at 268 (arguing that colonial and state precedents "were far more important in influencing federal law than Finglish examples"). This is a point that perades Hoffer and Hull's book. 
more so than in England, private citizens were only pursued through the regular criminal process or attainder but not impeachment, which was reserved for officers."

When the colonies broke formally from England and wrote their own constitutions, they made these limitations on impeachment clear. In every state where the legislature had the power to impeach, private citizens were excepted. ${ }^{62}$ By 1787 , then, "impeachment" had come to mean a process for the legislature to inquire into and prosecute public offenses by public officials.

With the exception of Pennsylvania, no colonial legislature actually had authority to initiate and try impeachments."' Parliament in England was the proper body to initiate and try such cases, and so colonial impeachment constituted a usurpation of sorts." Nevertheless, the need to hold public officials accountable-and oust them if necessary-occasionally became too important for colonial officials to leave to distant England. Hoffer and Hull have found sixteen cases of impeachment, near impeachment, or quasi-impeachment in the years between 1635 and $1776 .^{\text {.5. }}$

When the colonies declared themselves independent states and wrote constitutions, most of them provided an impeachment power for their respective legislatures. Impeachments picked up where they left off, holding public officials accountable for their public offenses.

61. See id. at 14 ("From the first . . the American cases showed pronounced departures from English precedent. The Americans accused wete Invallably officeholders . . . ."). But see zd. at 28-30 (describing Massachusetts case of merchunt captain Samuel Vetch, whose case was labeled an attainder but which resembled impeachment in some respects).

62. C. infra Part III.B.2.

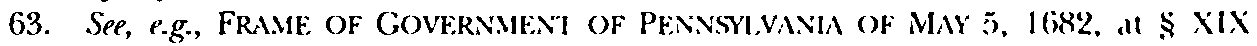
("[T]he General Assembly shall continue so long as may be needful to mpeach criminals . . . .); see also ChIARTER OF PRIVIL.Eges OF OCTOBER 28, 1701, at \$ 2 (gi antung Assembly the power to impeach "criminals"); FRALE OF GOVERNMENI OF PFNNSTI VAVII OF NOVEMBER 1, 1696 (same); FRAME OF GOVERNMENT OF PENNSTIVINIA OF FH BSI IRY 2. 1683 (same).

The Massachusetts judicial code provided before 1684 for "impeachment," but by the General Court. See HOFFer \& HuLt, supra note 1, at 11, 28.

64. See HOFFER \& HU1.L, supra note 1, at 9 ("Americans first adopted impea hment because they grasped its utility and were not told to desist, and continued to impeach even when proprietors and crown councillors explicitly told the colonists to stop"): Belkiap TRLAL, supra note 18, at 149 (opinion of Senator Dawes) (discussmg inherent colonial power to impeach).

65. See HOFFer \& HLLL, supra note 1, at 15-56 (describing colonial impeachment cases, as well as others that resembled impeachment). 
It was in the pre-constitutional state period that late impeachment first occurred in America. In 1781, ex-governor Thomas Jefferson of Virginia was subjected to preliminary impeachment proceedings for his conduct in office, though in the end he was not impeached. ${ }^{6}$ In February 1787, Vermont impeached former assemblyman Jonathan Fassett for participating in a rebellion. The impeachment followed the decision by the Assembly not to reseat Fassett, so he was out of office when impeached and when tried. ${ }^{67}$ He was convicted and disqualified from future state office." In both Virginia and Vermont, however, late impeachment was specifically referenced in the state constitution. ${ }^{69}$

\section{State Constitutions}

The federal Constitution was not the first modern written constitution; it was preceded by twelve state constitutions that influenced it heavily. As such, pre-1787 state constitutions are obviously useful sources for understanding the federal impeachment power. ${ }^{\text {.0 }}$

Twelve states (all but Connecticut and Rhode Island, and including Vermont) wrote constitutions before the federal Constitution was drafted in 1787. Ten of the twelve (all but Georgia and Maryland) had impeachment provisions in their state constitutions. Given the revolutionary spirit of antimonarchism prevailing in the states, it was hardly surprising that this strong check on executive power was written into most constitutions." The biggest dispute was over what body should try impeachments; the question of the timing of trials animated less debate. ${ }^{72}$

The following are excerpts from state constitutional impeachment provisions, in chronological order of adoption.

66. See id. at 85-86 (describing Jefferson case).

67. See id. at $84-85$ (describing Fassett case).

68. Id. at 85 .

69. See infra text accompanying notes 74 and 83 .

70. See Gordon S. Wood, Foreword: State Constitutson-llakeng in the Amencan Rnoblutson, 24 RUTGERS L.J. 911, 911, 925 (1993) (discussing broad influence of state consututions on federal Constitution).

71. See WOOD, supra note 29, at 141 ("Nothing indicates better how thoroughh Americans were imbued with Whig apprehensions of misapplied ruling power than their rather unthinking adoption of this ancient English procedure . . . - ).

72. See id. at 142 (describing state debates over the proper boxds to in impeachments). 
The specifications of who can be impeached are italicized, and specifications of timing are in boldface.

$$
\text { Virginia }(6 / 1776)
$$

The Governor, when he is out of office, and others, offending against the state, either by mal-administration, corruption, or other means by which the safety of the state may be endangered, shall be impeachable by the House of Delegates. Such impeachment to be prosecuted ... in the General Court, according to the laws of the land. If found guilty, he or they shall be either for ever disabled to hold any office under government, or be removed from such office pro tempore, or subjected to such pains or penaltics as the laws shall direct.

... [T] he Judges of the General Court ... may, in like manner, [be] impeach[ed] . . ."

New Jersey $(7 / 1776)$

[T]he Judges of the Supreme Court . . I, I the Jutges of the Inferior Court of Common Pleas in the several Counties, Justices of the Peace, Clerks of the Supreme Court, Clerks of the Inferior Court of Common Pleas and Quarter Sessions, the Altomey-(ieneral, and Provincial Secretary, . . . and the Provincial Treasurer . . shall be liable to be dismissed, when adjudged guilty of Misbehaviour by the Council on an Impeachment of the Assembly."

\section{Delaware $(9 / 1776)$}

The president, when he is out of office, and within eighteen months after, and all others offending against the Siate, either by maladministration, corruption, or other means, by which the safety of the Commonwealth may be endangered, within eighteen months after the offence committed, shall be impeachable by the house of assembly before the legislative council .... If found guilty, he or they shall be cither forever disabled to hold any office under government, or removed from office pro tempore, or subjected to such pains and penalties as the laws shall direct. And all officers shall be

73. VA. CONSI of 1776, art. XVI (emphasis added).

74. Id. at art. XVII (emphasis added).

75. N.J. CoNst of 1776, art. XII (emphasis addeded). 
removed on conviction of misbehavior at common law, or on impeachment, or upon the address of the general assembly: "

\section{Pennsylvania $(9 / 1776)$}

The general assembly of the representatives of the freemen of Pennsylvania . . . may . . impeach state criminals."

Every officer of state, whether judicial or executive, shall be liable to be impeached by the general assembly, either when in office, or after his resignation, or removal for maladministration ....

North Carolina $(12 / 1776)$

[T] he Governor and other Officers offending against the Statte, by violating any Part of this Constitution, Mal-Administration, or Corruption, may be prosecuted on the Impeachment of the General Assembly ....

\section{New York $(4 / 1777)$}

[A] court shall be instituted for the trial of impeachments . . . to consist of the president of the senate, for the time being, and the senators, chancellor, and judges of the supreme court, or the major part of them; except that when an impeachment shall be prosecuted against the chancellor, or either of the judges of the supreme court, the person so impeached shall be suspended from exercising his office until his acquittal ... 80

[T] he power of impeaching all officers of the Silate, for mal and corrupt conduct in their respective offices, be vested in the representatives of the people in assembly; but that it shall always be necessary that wo third parts of the members present shall consent to and agree in such impeachment. That previous to the trial of every impeachment, the members of the said court shall respectively be sworn truly and impartially to try and determine the charge in question, according 10

76. DEL. CONST. of 1776, art. 23 (emphasis added).

77. PA. CONST. of 1776 , ch. II. $\$ 9$ (emphasss added). Penusshamit's preindependence Frames of Government gave the colonial assembly the power to unpeath "criminals." See supra note 63.

78. PA. CONST. of $1776, \mathrm{ch}$. II, $\$ 22$ (emphasis added).

79. N.C. CONST. of 1776, art. XXIII (emphasis added).

80. N.Y. CONST. of 1777 , art. XXXil. 
evidence; and that no judgment of the said court shall be valid unless it be assented to by two third parts of the members then present; nor shall it extend farther than to removal from office, and disqualification to hold or enjoy any place of honor, trust, or profit under this State. But the party so convicted shall be, nevertheless, liable and subject to indictment, trial, judgment, and punishment, according to the laws of the land. ${ }^{81}$

\section{Vermont $(7 / 1777)$}

[T] he General Asembly [sic] of the Representatives of the Freemen of Vermont . . may . . . impeach Stale criminals. ${ }^{\text {'2 }}$

Every officer of State, whether judicial or executive, shall be liable to be impeached by the General Assembly, either when in office, or after his resignation, or removal for maladministration .....

\section{South Carolina (3/1778)}

[T]he form of impeaching all officers of the State for mal and corrupt conduct in their respective offices, not amenable to any other jurisdiction, be vested in the house of representatives. But . . . it shall always be necessary that (wothird parts of the members present do consent to and agrec in such impeachment. That the senators and such of the judges of this State as are not members of the house of representatives, be a court for the trial of impeachments, under such regulations as the legislature shall establish, and that previous to the trial of every impeachment, the members of the said court shall respectively be sworn truly and impartially to try and determine the charge in question according to evidence, and no judgment of the said court, except judgment of acquittal, shall be valid, unless it shall be assented to by two-third parts of the members then present . . 81

81. Id. at art. XXXIII (emphasis added).

82. Vr. CONST. of $1777, \mathrm{ch} .2, \$ 8$ (emphasis added). The substance of thus povisuon remained in the revised Vermont Constitution of 1786 , ch. $2, \$ 9$.

83. VT. CONSI. of 1777 , ch. $2, \$ 20$ (emphasis added). The substance of this provision remained in the revised Vermont Constitution of 1786 , ch. $2 . \$ 21$.

84. S.C. CONST. of 1778, art. XXIII (emphasis added). An carlier (1776) constitution for South Carolina made no provision for impeachment. 
Massachusetts $(3 / 1780)$

The House of Representatives shall be the Grand Inquest of this Commonwealth; and all impeachments made by them shall be heard and tried by the Senate.

The Senate shall be a court with full authority to hear and determine all impeachments made by the House of Representatives, against any' officer or officers of the Commonzuealth, for misconduct and mal-administration in their offices; but, previous to the trial of every impeachment, the members of the senate shall, respectively, be sworn truly and impartially to try and determine the charge in question, according to the evidence. Their judgment, however, shall not extend further than to removal from office, and disqualification to hold or enjoy any place of honor, trust, or profit under this commonwealth; but the part so convicted shall be, nevertheless, liable to indictment, trial, judgment, and punishment, according to the laws of the land. ${ }^{\text {wo }}$

\section{New Hampshire (6/1784)}

The house of representatives shall be the grand inquest of the state; and all impeachments made by them, shall be heard and tried by the senate. ${ }^{87}$

The senate shall be a court, with full power and authority to hear, try, and determine, all impeachments made by the house of representatives against any officer or officers of the state, for bribery, corruption, malpractice or maladministration, in office ... ${ }^{88}$

Their judgment, however, shall not extend further than removal from office, disqualification to hold or enjoy any place of honor, trust, or profit, under this state, but the party so convicted, shall nevertheless be liable to indictment, trial,

85. MASs. CONST. of $1780, \mathrm{pt}$ I, ch. I, $\$ 3$, art. 6. In 1778, Missichusets rejected a proposed constitution that would have vested in the House "the power of umpeachung all officers of the State for mal-conduct in their respective offices. Jot RiAl. Of nit. CONVENTION FOR FRAMING A CONSTITLTION OF GOVERNMESI FOR MIt. SIATE OF MASSACHUSETTS BAY, FROM THE COMMENCEMENT OF THEIR FIRSI StSSION, St.P It.MIBt.R 1 . 1779, TO THE ClOSE OF THEIR LAST SESSION. JLNE 16, 1780, at 255, 262 (Boston, Dutton and Wentworth 1832).

86. MASS. CONST. of 1780 , pt. I, ch. I, $\$ 2$, art. 8 (emphasis added).

87. N.H. CONST. of 1784 , pt. II, art. 17.

88. Id. at art. 38 (emphasis added). The earlier (1776) consututuon for Vien Hampshire made no provision for impeachment. 
judgment, and punishment, according to the laws of the land."

Several important patterns emerge from these state provisions.

First, they make clear the poor drafting of the fedcral Constitution-which specifies only that officers shall be removed if convicted, not directly that Congress has the power to impeach officers in particular-given the abundance of clear constructions in the state constitutions. In each of these state provisions (with the exception of New Jersey), the designation of who can be impeached appeared alongside the grant of authority to the legislature to pursue it." In six states (Massachusetts, New Hampshire, New York, Pennsylvania, South Carolina, and Vermont), the authorization took the form of a limited grant of power: i.e., "the legislature has the power 10 pursue public offenders through impeachment." In the other three (Delaware, North Carolina, and Virginia), the authorization took the form of an explicit limitation on the officers themselves: i.e., "public officers can be pursued through impeachment by the legislature." Though it is conceivable that others could be impeachable as well, the fact that there is no provision for anyone else to be impeached suggests that only officers are subject to that form of penalty." Only New Jersey foreshadowed the poor wording of the federal Constitution, in which impeachment is only mentioned obliquely in a removability provision that gives little inkling as to whether others (removed or not) may be impeachable as well.

A second pattern is that in each constitution, late impeachment was either required, permitted, or not discussed, but was nowhere explicitly forbidden. The first state constitution to feature impeachment, "2 Virginia's, was practically English in scope: it almost seemed to allow impeachment of anyone, not

89. Id. at art. 39 .

90. Justice Story noted that the purported limits on who could be mpede hed and for what would have been better placed in Article I of the Constitution rather th.un Article II. See 2 STORY, supra note 42, at 255 ("By some strange inadvertence, thus patt of the constitution has been taken from its natural comexion, and with no great popuets: arranged under that head, which embraces the organization, and rights, and duties of the evecutive department.").

91. Sep infra text accompanying notes 189-97.

92. New Hampshire and South Carolina drafted constitutuons before linguma did. but neither provided for impeachment. Sep N.HI. CONSI of 1776; S.C: CoNsI of 1776 
just officers, who offended against the state," and it did not limit the potential range of penalties. The principal limit it imposed was that the Governor could not be impeached until he left office. Implicitly, other officials could be impeached in or out of office. To the Virginia drafters, then, late impeachment was not only potentially worthwhile, it was the only acceptable way to proceed against the Governor. To be sure, this may reflect the fact that the Governor's term was only one year and that he was chosen by the legislature, making removal less important." But for' the Governor, at least, impeachment was very' clearly about accountability rather than removal.

The Delaware Constitution adopted the Virginia formulation, with a slight variation. Delaware added an eighteen-month statute of limitations for impeachments, tolled for the "president" (Delaware's title for governor) until he left office. Other officeholders could be subjected to late impeachment, too, if they left office before the eighteen-month period expired. In Delaware as in Virginia, then, late impeachment was possible for any official and was the only way to proceed against a governor.

Another early effort, the Pennsylvania Constitution of 1776 , gave late impeachment a more nuanced treatment. Like Virginia, impeachment almost seemed as if it were not limited to state officers; ${ }^{95}$ the General Assembly was authorized to impeach any "state criminal," just as it had been for decades before." But an executive or judicial state official qua state official could not be impeached once his term of service had expired naturally. If he was still in office or if he had resigned or been removed, he could be impeached. Late impeachment was possible, in other words, but only against those officers who had left office under abnormal circumstances. This made it clear that impeachment was about accountability and not just removal, so much so that the officer could not preempt proceedings by resigning or by being so bad that the legislature removed him in advance of his

\footnotetext{
93. See infra text accompanying note 102 (explaining limitatuon of Virguma impeachment to officers).

94. See VA. CONST. of 1776, art. IX.

95. See infra text accompanying note 103 (cxplaming inherent humatuon of Pennsylvania and Vermont impeachment to officers).

96. See supra note 63.
} 
impeachment trial. ${ }^{n}$ Vermont copied Pennsylvania's formulation.

Five other states' impeachment provisions-North (arolina," New York, South Carolina, Massachusetts, and New Hampshire-did not specify that late impeachment was acceptable, but neither did they forbid it. Writing as they were against the backdrop of the Virginia and Pennsylvania formulations that provided for late impeachment, one might have expected these newer efforts to be explicit if they were making such a fundamental change.

To be sure, one can argue that they were being explicit-by conspicuously omitting the Virginia/Pennsylvania broader timing language. But the Virginia language was a limit on timing; Virginian Governors and Delawarean Presidents could only be impeached after leaving office, so removing that language would presumably have added an option (i.e., regular impeachment), not subtracted one. Pennsylvania (and Vermont) barred impeachment of officers whose terms had expired naturally; removing that language just as easily could have been meant to expand impeachment as to restrain it. Moreover, after explicitly allowing late impeachment, Pennsylvania used the term "officer" to describe those who were officers when they committed crimes, not just those who were officers at the time of impeachment. Later constitutions, speaking only of officers without reference to timing, could just as easily have been using the term with similar breadth.

Furthermore, four of these states were explicit in placing other limits on impeachment that earlier state constitutions lacked. New York invented-and specified-the requirements of twothirds majorities, a special oath for impeachment judge's, and a ban on punishments greater than removal and disqualification. South Carolina, Massachusetts, and New Hampshire followed suit, in part. The eventual language in the U.S. Constitution closely tracked the language of these four states' constitutions.

97. See PA. CoNSr. of 1776 , ch. II, \$ 34 (making probate officers remowable at the will of the general assembly).

98. Note that North Carolina's provision was much marrower in $\operatorname{scope}$ than 11 counterparts. It used impeachment as a first step in allowing crminal posecutuon of officeholders. It did not specify removal-or anything else-as at penalts. It 1 mph substituted the General Assembly for a grand jurv in the regular criminal process, in the case of public offenses. See supra note 79 . 
Despite adding these specific limitations on the impeachment powers, these four states added no specific limitation on the timing of impeachment. Significantly, though, they did specify that the offenses covered by impeachment were only those committed while in office. This made clear that impeachment did not reach private conduct or private parties. Moreover, it made clear that impeachment was not designed just to remove bad men from office-private offenses committed prior to taking office were exempt from review via impeachment. Thus, impeachment in these four states was not designed to keep criminals out of public office, it was designed to keep officers from becoming public criminals.

A critic of late impeachment could argue that things like twothirds majority requirements are not self-evident and, therefore, require specification, and that late impeachment is similarly counterintuitive and also requires specification. V'irginia specified late impeachment and not two-thirds majorities; New York specified two-thirds majorities and not late impeachment. But as noted above, the Virginia, Delaware, Pennsyilania, and Vermont formulas made specific reference to late impeachment in the context of limiting it, while using language that suggested that late impeachment was otherwise implicitly permissible. Therefore, allowing late impeachment is the selfervident proposition, not the counterintuitive one, and failure to explicitly bar it while specifying other limitations on the impeachment power is a telling omission.

Another potential point against state late impeachment is that the Virginia, Delaware, Pennsyliania, and Vermont constitutions, which explicitly allowed late impeachment, also suggested that any "state criminal" or "offend[er] against the state" could be impeached, not just officers." By contrast, the newer constitutions specifically limited impeachment to officers. ${ }^{100}$ A critic thus could argue that late impeachment was implicitly permissible only in those states where holding office

99. See HOFFER \& HULL, supra note 1. at 70 (describmg "aghueness" of Virgma language that might have allowed for impeachment of pmatte ciusens and exefficen): BELKNAP TRIAL, supra note 18, at 121 (opinion of Senator Allison) (argung that Virgma and Delaware Constitutions allowed impeachment of non-efficers): supra iext accompanying notes 77-78 (stating Pennsyluania's impeachment provistons): supra text accompanying notes $82-83$ (stating Vermont's impeachment provistons).

100. In Massachusetts, a proposal to allow impeachment of non-officen was specifically proposed and rejected. See supra note 85: Horrt. \& H H 1 , supra note 1 , .t 76. 
was not a requirement for impeachability. In states where private citizens could not be impeached, it would not be self-evident that impeachment could reach people who were no longer in office. But even to the extent that this might be true as a matter of technical textual construction, it does not resonate with the actual practice of impeachment. There are no instances of impeachment being used against private citizens-other than ex-officers-in any' state. ${ }^{1 \cdot 1}$ Indeed, read in context, the text of the older constitutions supports this more limited construction. For instance, the grounds specified for impeachment in Virginia and Delaware-maladministration and corruption-would secm to apply only to public officials, and there is evidence that the Virginia language was meant to expand the class of offenses, nof the class of offenders. ${ }^{102}$ In Pennsylvania and Vermont only maladministration was specified, and the term "state criminal" appears to refer only to officers (i.e., administrators, allegedly mal). Later case law bears out this interpretation." ${ }^{103}$

In sum, state impeachment provisions fell into two broad categories. The first group both provided for and implied the underlying propriety of late impeachment. The sccond grotup, which more directly influenced the federal Constitution, did not attempt to limit the scope of late impeachment enshrined in earlier state constitutions. States designed impeachment as a means of ensuring accountability for official action rather than simply a mechanism for removing "bad men" from office. In some states late impeachment was actually performed and

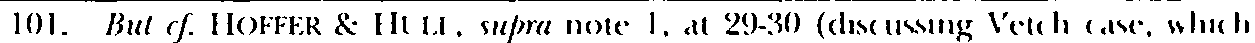
involved private citien and had impeachment-like qualities despite heomg labeled attainder).

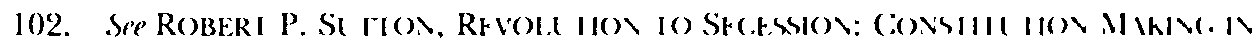
WHF OID DONIVION 43 (1989) (describung a diaft of the Virginia comstumen wheh clarifies that "safets of the State" language was part of the definutuon of mpeachable offense's for executive officers).

103. Se State เ. Campbell, 2 Tvl. 177. 182 (V't. 1802) ("In cases of m.1 administration there is a peculiar and mantest proprtets 11 . . . bungung State ammmals. as thev are styled in the constitution, to trial before this high notumal inbumal, whene the solemnity and publicity of the trial will either publicls puge then offical hasums fom imputed crime, or make their mal-admenstraton known to the (It1/ens al luge, and especially to those in whom rests commonly the electum to offire.") (emphisis aldecl). Harris v. Huntington, 2 Tyl. 129, 144-45 (Vt. 1802) ("It is 10 be observed, that though it is true the house of representatives have no power to try persons for crumes, set "l does ilut follow that thes may not examine into the conduct of officers of gomermment. Ilwe constitution gives the power to the house of expresentatuves. . Io mpenth sostr crmmonals.") (emplasis added). 
authorized, and where it was not, it was at least compatible with the text and structure of state impeachment.

\section{The Articles of Confederation}

The Articles of Confederation, drafted in November 1777, did not contain any provision for the impeachment of national officers. In 1786, as it became apparent that a stronger national government was needed, the Congress appointed a committee (which included two eventual delegates to the constitutional convention) to draft amendments to the Articles." ${ }^{13}$ The amendments were reported in August 1786, six months before the constitutional convention was called but were never acted upon..$^{105}$

Among the amendments were two that touched on the issue of impeachment. The proposed Article 9 authorized the unicameral Congress to "institute a federal Judicial Court for trying and punishing all Officers appointed by Congress for all crimes, offences and Misbehaviour in their Offices . . . . " proposed Article 20, directed at ensuring sufficient attendance in Congress, authorized Congress to punish delegates who failed to attend when required by Congress or withdrew without either permission from Congress or a recall from their state, though the punishment could not be "further extended than to disqualifications any longer to be members of Congress, or to hold any Office of trust or profit under the United States, or any individual State . . . ."107

Neither of these provisions used the word "impeachment." Both, however, established the power to punish officials for dereliction, and both were directed at accountability, not removal per se. Indeed, the punishment for AW'OL delegates to Congress presupposed that the party was, in a sense, out of office.

These proposed amendments to the Articles of Confederation, while not shedding abundant light on the

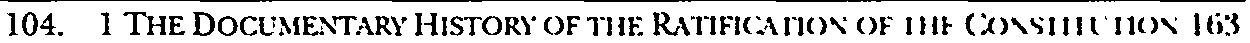
(Merrill Jensen ed., 1976) (mentioning that future framers (harles Punchnes and William Houstoun were on this "grand committec").

105. Id.

106. Id. at 167.

107. Id. at $167-68$. 
question of late impeachment, nevertheless provide more positive data.

\section{The Framers and the Ratifiers}

The Framers established the federal constitutional impeachment power against the backdrop of English, colonial, and state impeachment doctrine described above. Their intent with regard to late impeachment is unclear. The notes on the convention debates are sketchy at best and do not directly address the issue of late impeachment. They do, however, provide tantalizing bases for an inference that late impeachment was acceptable to the Framers or, if not intended, was at least not intentionally subtracted from the congressional impeachment power. This is especially significant given that a well-known English impeachment case-a late impeachmentwas proceeding as the convention sat.

Many Framers considered the state ratification debateswhich, unlike the convention debates, were not secret- the most valid source for construing the original understanding of the provisions in the Constitution. ${ }^{108}$ Unfortunately, the state ratification debates provide only sketchy evidence toward resolving the puzzle of late impeachment. They do suggest, though, that the impeachment power was understood as being quite broad. While the federal impeachment power was more closely connected with removal than its state counterparts had been, it remained grounded in a desire for accountability and deterrence. Late impeachment may not serve the former goal, but it certainly serves the latter.

\section{The Convention}

By the time of the constitutional convention, the revolutionary ideology had been transformed in significant ways. The fear of executive power that informed state constitutions had shifted; now the legislature was the branch to constrain, and

108. Sep, e.g., Ronald D. Rotunda, Ongunal Intent, the liene of the Framers, and the Role of the Ratifiers, 41 ViVD. I. REv. 507, 512 (1988) "When we talk populats about the framers" intent, we really should be more precise and refer to the ratifiess intent. wh,t Alexander Hamilton in The Federalust Papers called the intention of the pe(ople." $)$. Ne.

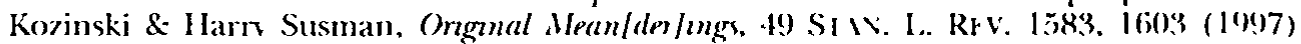
(discussing Madison's reliance on the ratifiers mtent in interptetung the (omstitutuon) 
tolerance for executive power had increased." That said, impeachment was still considered a necessary check on executive (and judicial) power.

Delegates came to the convention aware of their own state constitutions and precedents, and of English precedents. "'" The Framers discussed impeachment at length and on several separate occasions at the convention. The issue of late impeachment never arose explicitly, but several of the discussions provide bases for inferences about the Framers' understanding of late impeachment, and suggest that late impeachment was accepted. ${ }^{111}$

\section{a. Initial Proposals}

Impeachment was placed on the table almost from the start of the convention. On May 29, Edmund Randolph offered the "Virginia Plan," which formed the baseline for subsequent discussion over the next few weeks. In it, Randolph followed the Virginia state structure of having impeachment trials in regular courts: He proposed that the federal supreme court would "hear and determine . . . impeachments of any National officers. "1"

On June 2, the Committee of the Whole, working from Randolph's proposal, came to discuss the remorability of the President. John Dickinson of Delaware proposed that the

109. See WOOD, supra note 29 , at 409 ("Where once the magistran had secmed to be the sole source of tyranny, now the legislatures through the Revolutionary state constitutions had become the institutions to be most feared."): see also llofrt. \& HIt 1. . supra note 1, at 60 ("Without a king to shield wrongdoers in office. without an anstocran to protect their own from public outery, was there any need for impeischment:").

110. BELKNAP TRIAL, supra note 18, at 363 (discussing familiantv of framers with state constitution impeachment provisions); HoFfer \& Hitl. supra note 1 , at 96 (discussing familiarity of Framers with state impeachment law and cases): Bk.R(.t.R, supres note 29, at 87 n.160 (describing American familiarity with English impeachment law). Hoffer and Hull go further in downplaying the English influence, sirnng that Englsh impeachment precedent "had receded into a dim past." despite the contemporancous Hastings case. HOFFER \& HULL, supra note 1, at 96. Ther also enticue Berger's assumptions, asserting that the Framers used English cases as "counterexamples and passing illustrations" rather than relying on them as good law. Id. at 266-70.

111. Other discussions on impeachment, particularl the exhatusue discusstons orer which body should try impeachments, are not discussed in this Part, as ther do not implicate the late impeachment issue.

112. 1 THE RECORDS OF THE FEDERAL. CONVEITION OF 1787, at 22 (Max F.urrand ed. 1911) [hereinafter RECORDS]. At the same time. Charles Pincknes introduced his own draft constitution, which gave the House the power to impeach and established the Senate and Supreme Court as the impeachment court. paralleling the structure in South Carolina. Pinckney provided separatelv for the removal of the President was impeachment. This account of Pincknevs Plan is based on that preced together br Farrand. See 3 id. at $606,608$. 
President be removable by Congress on the request of a majority of state legislatures, a notion that no other delegation supported. ${ }^{113}$ The next removability proposal, however, was approved: The delegates voted to make the President "removable on impeachment and conviction of mal-practice or neglect of duty." "It At this stage in the drafting, then, impeachment applied to all national officers, while removability and the standards for it were discussed only in the context of a sitting President.

Significantly, four states voted against making the President removable on impeachment: Maryland (which had no provision for impeachment in its state constitution), Virginia, Delaware, and Pennsylvania." Recall that in the Virginia and Delaware constitutions, the governor was not impeachable while in office."' At home, these states supported the idea of impeachment for officers in general and for the governor in particular. At the convention, their delegations offered no objection to a parallel structure for the federal constitution. It is readily inferable, therefore, that while the Virginia and Delaware delegations opposed the idea of removing a sitting President by impeachment, they would not have objected to lal' impeachment of the President." Pennsylvania too allowed late impeachment, and its delegation may have felt the same way as Virginia and Delaware.

The next development came on June 15, with the introduction of William Paterson's "New Jersey Plan," a broad counterproposal to Randolph's Virginia Plan. The New Jersey Plan also provided for impeachment trials of "federal officers" to be performed in the federal courts, but separately advanced the Dickinson proposal that the President be removable by (ongress on application of a majority of state legislatures. ${ }^{11 x}$ Once again this proposal went nowhere, but like Randolph, Paterson had provided a general power to impeach national officers and a

113. See 1 wh at $85-87$.

114.1 id. at 78 .

115. 1 ud. at 79 .

116. See supra text accompanying notes $74 \& 76$.

117. To the contrary, though. Dickinson had made his proposal for state-bused removal of the President because "[h]e did not like the plan of impeachung the cited Officers of State." 1 RECOORDS, supra note 112, at 85.

118. 1 ud. at 244. 
wholly separate provision ensuring the removability of the President.

On June 18, Alexander Hamilton proposed a broad plan as well, in which it was specified that "The Governour [i.e., President,] Senators and all officers of the United States to be liable to impeachment for mal- and corrupt conduct; and upon conviction to be removed from office, \& disqualified for holding any place of trust or profit .... ${ }^{n ! \prime}$ Here and elsewhere, Hamilton seemed to believe that removal was a required component of the impeachment penalty, which suggests that he viewed late impeachment as impossible. On the other hand, Hamilton's later writings on impeachment in The Federalist Papers-construing the Constitution as actually written and not his own unadopted proposals-can be construed more favorably to late impeachment.

\section{b. Removing the President}

In late July, an intense debate raged over the impeachability of the President, which remained in the working draft (based on the Virginia Plan). Some, fearing that the proposed legislature was already much more powerful than the proposed President, did not want to place the President at the mercy of the Congress; instead, they would have adranced accountability by replacing impeachment with short terms and the possibility of re-election. ${ }^{122}$ Many of the comments emphasized the importance of being able to remove a sitting President through impeachment; this focus gives an undue impression that late impeachment was not considered possible, when in fact the issue simply was peripheral. ${ }^{12 s}$ The same was true of comments on the other extreme, which argued against any impeachment of the President, implicitly excluding late impeachment as well, but not addressing the timing issue per se. ${ }^{1: 4}$

In one instance, however, the debate avoided these extremes and provided a glimpse, albeit vague, of some Framers'

119. 1 id. at 292.

120. See 3 id. at 626-27 (discussing a plan by Hamlen that wiss not pesented, whech would have limited punishment to removal or removal plus disfualification)

121. See infra text accompanying note 145 .

122. See 2 RECORDS, supra note 112 , at 53. At that pomt in the debute, the Prestdent was impeachable, served six years, and could not be reelected. 22 ut at 51

123. See, e.g., 2 id. at $66-67$ (comments of Pinchnes and King)

124. See, e.g., 2 id. at 65-69 (comments of Madison. Rundelph, and Moms) 
understandings of late impeachment (to the extent that Madison's notes of the occasion are reliable). On July 20, immediately after Charles Pinckney and Gouverneur Morris moved to strike the provision authorizing removability of the President, the following exchange occurred:

Mr. P[inckney] observd. he ought not to be impeachable whilst in office.

Mr. Davie. If he be not impeachable whilst in office, he will spare no efforts or means whatever to get himself re-clected. He considered this an essential security for the good behaviour of the Executive.

Mr. Wilson concurred in the necessity of making the Executive impeachable whilst in office.

Mr. Gorr. Morris. . . . In case he should be re-elected, that will be sufficient proof of his innocence... .

Col. Mason. No point is of more importance than that the right of impeachment should be continued. Shall any man be above Justice? . . One objection agst. [the Electoral College] was the danger of their being corrupted by the Candidates: \& this furnished a peculiar reason in favor of impeachments whilst in office. Shall the man who has practised corruption \& by that means procured his appointment in the first instance, be suffered to escape punishment, by repeating his guilt?

This debate was not really about impeachment-it was about removability. ${ }^{12 k}$ The clause that Pinckney was trying to eliminate provided that the President was "to be removeable," 227 not that he "be impeachable." National officers were gencrally impeachable; the issue here was, as Pinckney put it, whether the President (whose term was otherwise definite and limited) ought to be "impeachable whilst in office." In other words, Pinckney arguably presupposed the possibility of late impeachment, and was concerned only with whether "regular" impeachment was acceptable as well. ${ }^{128}$

125. 2 id. at 64-65.

126. See $t d$ at $185-86$ (recording draft from (ommittee of Detall placung removability provision between provisions for presidential oath and vice prestlentlal succession); 2 id. at 499 (recording recommended language from (ommittec of Eleven placing removability provision in same clause as succession proviston).

127. 2 ud. at 64.

128. But sep BELK.AP TRLAL, supra note 18, at 119 (opinon of Senator Nllison) (flats stating-without citing ans support-that Pincknes opposed anv mpeahment of the President at anv time). 
William Davie responded to Pinckney that "regular" impeachment was important because if it were not available, the President would attempt to win reelection by any means necessary. Davie, who came from North Carolina, where late impeachment was not discussed in the constitution, could have meant two things by this. First, Davie might have presupposed that late impeachment was possible and argued that if only late impeachment were available, a malfeasing President would entrench himself in office to avoid it. ${ }^{1 *}$ Alternatively, Davie could have meant that a President could entrench himself in office if he corruptly won reelection and there was no other means of removing him-in which case late impeachment would never be an issue.

Madison next described James Wilson as using the same "whilst in office" construction.

Gouverneur Morris had more faith than Davie in the Electoral College, but George Mason shared Davie's concern about a President who would do anything to get reelected. Notably, however, Madison quoted Mason as speaking of the right of impeachment being "continued," as opposed to it merely being "available." This suggests that to Mason, the issue was whether impeachment would be suspended during the President's term or instead would be continuous. The word "continued" makes little sense if the only options were either impeachment in office or none at all. In other words, Mason appeared to presuppose late impeachability.

Mason's final comment, that a President could "escape punishment" for fixing an election by fixing the next one, reveals a similar presupposition. If late impeachment were not an option, then reelection would not allow the President to "escape" anything: Once his new term ended, he would not have to face impeachment. Of course, Mason might also have feared a President stealing every election and staving in power for life. If he were able to win every election and was not susceptible to removal, then he would indeed escape punishment. ${ }^{16}$ But as

129. See id. at 53 (argument of House manager in bate mpeachunent tral dexcusing Davie statement, and arguing: "What good would it do hum to be icelected at he could not be impeached anyway if he was out of office:"); id. at 150 (opmun of Sentur Dawes).

130. This concern of Davie's and Mason's was mooted by the Twentw-Second Amendment. U.S. CONST. amend. XXIl ("No person shall be elected to the oflice of the President more than twice . . . .). Now, the President must leatse office erentualls 
with Davie, if this is what Mason meant, then his comments did not implicate late impeachment at all.

This brief exchange about whether the President should be impeachable "whilst in office" therefore provides some cvidence to support the notion that late impeachment was considered possible by the Framers. The corps of national officers was to be impeachable; the only question was whether to exempt the sitting President. The impeachability of a former President-and thus of any former officer-was implicit or, at the very least, not ruled out. In the process, moreover, the notion was reinforced that impeachment is about accountability and deterrence ("providing essential security for the good behaviour of the Executive," as Davie put it) and not just removability."

\section{c. The Hastings Paradigm}

The next exchange providing inferences on the Framers' understanding of late impeachment did not come until September 8 , in the debate on defining impeachable offenses. Again, Madison's notes provide the crucial implications:

The clause referring to the senate, the trial of impeachments agst. the President, for Treason \& bribery, was taken up.

Col. Mason. Why is the provision restrained to Treason \& bribery only? Treason as defined in the Constitution will not reach many great and dangerous offences. Hestings is not gruil/y of Treason. Attempts to subvert the (Constitution may not be Treason as above defined-As bills of attainder which have saved the British Constitution are forbidden, it is the more necessary to extend: the power of impeachments. He movd. to add after "bribery" "or maladministration." Mr. ('erry seconded him-

Mr. Madison So vague a term will be equivalent to a tenume during pleasure of the Senate.

Mr. Gorr Morris, it will not be put in force \& can do no harm- An election of every four years will prevent maladministration.

(unless he can contrise some was to become Presclent wothout beng elected) 1 hes makes remorability less important and, conversels, makes late mpeathment mone relerant.

131. See mfia Part ViA. 
Col. Mason withdrew "maladministration" \& substitutes "other high crimes \& misdemeanors" (agst. the Statc).

Mason's offhand tone (if it was not just Madison's offhand notes) in referring to Hastings suggests that those present were familiar with the famous case. ${ }^{188}$ What is more readily inferable is that Mason wanted someone in Hastings's position to be impeachable. ${ }^{134}$ Mason's proposal, which broadened the range of impeachable offenses to include all high crimes and misdemeanors, was intended to ensure that a President who acted like Hastings would be susceptible to impeachment.

If Mason and the Framers knew anything about the Hastings case, though, they knew that Hastings was being subjected io a late impeachment. Yet, that aspect of Hastings's case attracted no negative comment. While late impeachment was not relevant to the discussion of removable impeachable offenses, Mason's comments are relevant to the larger question of how much the Framers meant to distinguish American impeachment from English impeachment. If aspects of the Hastings case-such as the fact that Hastings was out of office-were seen as unacceptable, it would be surprising if Mason would have used it as an example of a good impeachment and even more surprising if this attracted no dissent. Conversely, if the Hastings case was seen as an appropriate model, the fact that Hastings was out of office surely must have registered.

More generally, in defining impeachable offenses Mason moved away from the American "maladministration" standard"

132. 2 RECORDS, supra note 112, at 550) (emphasis added) (foomote ommted)

133. Even an opponent of late impeachment conceded generatuons hates that Hasuings's "case was present to all minds, and was debated b all lips." Bh.lhltl' Ikltl. supra note 18, at 98 (opinion of Senator Howe): see also Arthur Bestor. Impxethment, iy WASH. L. REV. 255, 284 (1973) (book review) ("As the proposed (ionsututun went before the ratifying conventions of the several American states 111 1758, the most spectacular impeachment trial of the age got under was un the House of lests."

Reference was made to Hastings in the First Congress as well. at wheh pentut the proceedings were still ongoing; it was mentioned unfasorabls ats andmple of how slow impeachment trials could be. I ANASAS OF CONG. 373 (1789) (statement of Rep) Vining).

134. Then again, maybe knowledge of Hastings's case was yput m dae New Wurld After all, one of the charges against Hastings was for briben (though not lolkeled .ts suh

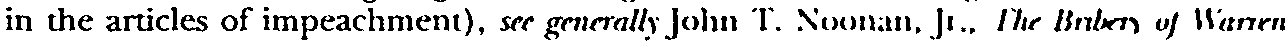

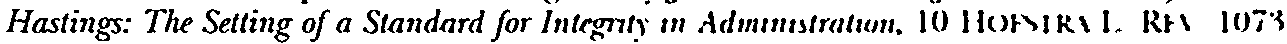
(1982), a fact that undermines Mason's entire argmment abeut bioddenung the list of impeachable offenses so as to ensure the inclusion of cases lihe Hlasungs',

135. Most state constitutions used this formulatuon. Se supn text .4 (omplumung notes $74-89$. 
to the English "high crimes and misdemeanors" standard. "' American federal impeachment was thus placed squarely in the context of the English experience, where not just high crimes and misdemeanors but late impeachment were the order of business. $^{137}$

\section{d. Late Adjustments}

Late in the convention, the provision for removing the President was expanded to make clear that he was not the only official subject to impeachment. To the provision for removing the President upon impeachment and conviction, the convention simply added the Vice President and civil officers to the list unanimously and without debate. ${ }^{138}$ This late change ended the distinction in the text between the general impeachment power and its specific application to presidential removal. It is also the source of the poor construction of Article II, Section $4 .^{139}$

One last item implicitly raised the issue of late impeachment, and at first glance it might seem to suggest that it was not intended. On September 14, John Rutledge and Gouverneur Morris proposed to suspend impeached officers pending their trial and acquittal. ${ }^{\prime \prime \prime}$ This proposal, which was rejected, "' suggests that impeachment was for sitting officers only. As with the earlier discussions on impeachment, though, it appears that this simply reflected the importance of removability to the Framers. It was not necessarily the case that all impeachments would involve sitting officers; Rutledge and Morris simply wanted to consider suspension as a remedy for those that did.

136. See BERGER, supra note 29, at 59-73 (describing English use of "high ( time" and misdemeanors" concept).

137. See supra text accompanying notes $52-58$.

138. 2 ReCORDS, supra note 112 , at 546,552 .

139. The late impeachment dilemma is not the only one created by the sloppen craftsmanship-the Framers also neglected to provide explicitly for someone othen than the Vice President to preside over an impeachment trial of the Vice President. See Joel K. Goldstein, Can the V'ice President Presade at Has Own Impeachment Tral?: A Crutuque of Bane Textualism, 44 ST. LOL'IS L. L.J. 849 (2000) (arguing against the abolity of the l'ice President to preside over his own impeachment trial); ser also Kalt, supra note 13, 1t 79596 (discussing incongruity of Vice President presiding over his own impeachment tral).

140. 2 REC ORDS, supra note 112 , at 612 .

141. Id. at 612-13. 


\section{e. Conclusion}

Quite a bit about impeachment went without saying in the debates, and the fact that something as admittedly peripheral as late impeachment was one of them should not be surprising. Nevertheless, the mention of Hastings and the debate on whether the President should be removable "whilst in office" provides some evidence for the notion that late impeachability was a given and that "regular" impeachment (for the President at least) was the controversial question.

Regardless of what the Framers knew or thought of the Hastings case, they clearly gave Congress a more restricted impeachment power than that possessed by Parliament. One can argue that when the Framers meant to eliminate an impeachment power from the English baseline, they did so explicitly. ${ }^{142}$ Conversely, when they were not explicit-as with late impeachment-they must not have intended such a limit. If the British could impeach Hastings after he had left office, this argument would go, so too could the Americans impeach an exofficer, in the absence of a constitutional statement to the contrary.

\section{Ratification}

Further insight on the original understanding of late impeachment can be gleaned from ratification sources. The Federalist Papers present neither direct evidence about the

142. See, e.g., BELkNAP TRlaL, supra note 18, at 87 (opmon of Senator Shermatn) ("The precedents of impeachment of persons not in office for offenses commuted while in office were well known, and if this had been considered an abuse to be guarded against it would have been done in the same clear manner that the Constutution guturds against excessive punishment in cases of impeachment."): ad. at 129 (opimon of Sentutor Bayard) (cataloguing explicit changes in Constitution awas from English practuce and not including prohibiting late impeachment).

These explicit changes include: the wo-hirds majorits requirement for commonon: limitation of impeachment to high crimes and misdemeanors by civi officers, but sex part IV.B.1; the limitation on presidential pardons to prevent their use (t) unde an impeachment judgment; and the limitation on punishment to semoval and disqualification.

On a separate note, English impeachment procedures were bought mto American practice as a baseline when Senate President Thomas Jefferson incorporated them into

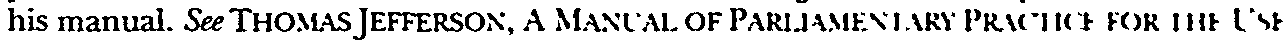
OF THE SENATE OF THE UNITED STATES \$ LIII (1801); see also Edwin Brown Firmage \& $R$. Collin Mangrum, Removal of the Prestdent: Resignatson and the Procedural lest' of Impeachment, 1974 DUkE L.J. 1023, 1031 (describing English procedure and Jefferson', adoption of it). 
original understanding of late impeachment, nor much valid basis for inference. There are, however, some invalid bases that bear mention given the prominence of The Federalist as a source for deciphering original understanding.

The first discussion of impeachment in The Federalist mentions late impeachment explicitly but does not discuss whether it is possible under the federal Constitution. In The liederalist 3\%, James Madison compared the republican character of the proposed constitutional government with those in the states. IC wrote:

In several of the States, however, no explicit provision is macle for the impeachment of the chief magistrate. And in Delaware and Virginia he is not impeachable till out of oflice. The President of the United States is impeachable at any time during his continuance in office."

Taken out of context, Madison's statement that the President "is impeachable at any time during his continuance in office" would seem to rule out late impeachment. But Madison was not speaking of the limits of the federal impeachment power; rather, he was speaking of its expansion. Unlike certain states where the governor cannot be impeached at all or can only be impeached after he leaves, Madison explained, the President can be impeached while he is in office." Later, Alexander Hamilton made the identical point, noting that "[T]he President of Confederated America would stand upon no betler ground than a governor of New York, and upon worse gromel than the governors of Virginia and Delaware." One can debate. whether a President who is only impeachable while in office is "on worse ground" than one who can only be impeached after leaving office-Hamilton may have been supporting the iclea of late impeachability. At worst, though, late impeachment was simply beside the point to Madison and Hamilton and not ruled out.

The only other potentially relevant discussions of impeachment in The Federalist concerned removability, and so, as

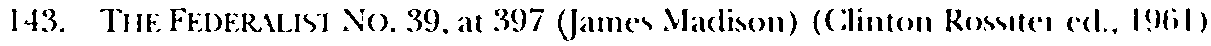

144. C. supra Part III.C.1.b (discussing removabiluty of President, unplyung hus late impeachability).

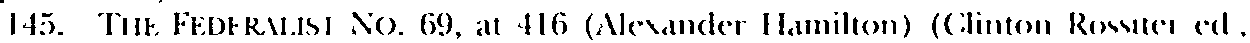
$19(1)$. 
in several debates in the convention, ${ }^{1 \text { to }}$ focused disproportionately on the impeachment of sitting officers. "As before, the fact that "regular" impeachment was more likely and more important-and that the discussion of impeachment reflects that fact-does nothing to rule out the possibility of late impeachment.

Impeachment was also discussed by opponents of ratification in the loosely organized canon known as the Anti-lederalist Papers. Here too, late impeachment was not addressed, but some inferences are available.

As in The Federalist, at least one anti-Federalist author discussed the removability of the President in terms that might seem to crowd out late impeachment-if read out of context. Luther Martin (who was a convention delegate, but who walked out and refused to sign the final document) objected that the Constitution made it too hard to remove the President via impeachment, given the likely contours of congressional politics. ${ }^{148}$ This would not be a problem if late impeachment were possible; the presidential leverage over Congress that Martin worried about would be mooted once the President left office. Thus, one might conclude that Martin did not think that late impeachment was possible; if he did, he would not have complained so stridently. But Martin was not thinking in such subtle terms. Martin was concerned that the President would be "a King in name, as well as in substance," who could "establish himself in office not only for his own life, but even if he chooses, to have that authority perpetuated to his family." Martin dismissed impeachment as irrelevant, because the President could "set [it] at defiance." This would be so for late impeachment too, if the President never left office. As with Hamilton and Madison, then, for Martin the timing of impeachment was beside the point.

In the actual state convention debates on ratification, impeachment was raised as an issue on several occasions, but again late impeachment was not addressed directly.

146. See supra text accompanying note 123.

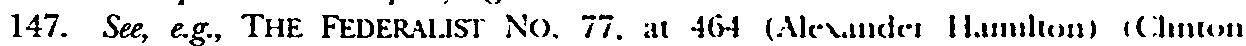
Rossiter ed., 1961); id. No. 79, at 474.

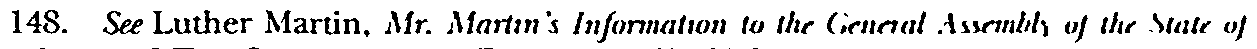
Maryland, in 2 THE COMPLETE ANTI-FEDER UIISI 27, 684-69 (Herbert J. Stonng ed, 1981)

149. 2 id. at 68 (emphasis removed).

150. 2 id. at 69 . 
One concern about impeachment among opponents of the Constitution was that the Senate was established as the tribunal for trial. Relatedly, many debaters assumed that senators themselves were civil officers, subject to impeachment. For instance, John Brooks expounded at the Massachusetts ratifying convention as follows:

When men are answerable, and within the reach of responsibility, they cannot forget that their political existence depends upon their good behavior. The Senate can frame no law but by consent of the Representatives, and is answerable to that house for its conduct. If that conduct excites suspicion, they are to be impeached, punished, (or prevented from holding any office, which is great punishment. $)^{1 ; 1}$

Brooks supported the impeachability of senators, in other words, and understood impeachment as being about much more than just removal. Apropos of late impeachment, Brooks understood removal, disqualification, or any combination thereof as a threat to one's political existence, a threat that provided proper incentives for "good behavior." Once again, we see impeachment conceived as a way to guarantec propricty in office-a goal to which late impeachment would contributerather than simply to remove malefactors from office.

An exchange at the North Carolina ratifying convention contained language that implicated late impeachment. In the context of a discussion of who was subject to impeachment. delegates puzzled over the Constitution's vague language and worried that slate officers and even private citizens might be susceptible to impeachment. "'i3 Governor Samuel Johnston rejected this notion, stating: "Removal from office is the punishment-to which is added future disqualification. How could a man be removed from office who had no office? Johnston's interpretation would seem to preclude late impeachment. If removal is a necessary element of punishment.

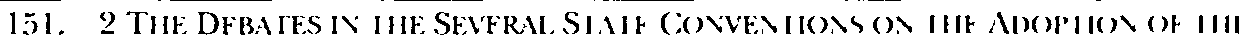

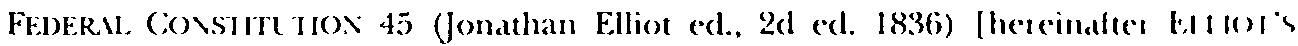
DEBA IES); sep also 2 ud. at $168-69$ (recording Samuel Stillman makmg the same pout)

152. One can read-but should not read too much-into Brooks's use of the word "or," implying that disqualificatoon alone was a possible punishment (as 11 would necessarily be in a late impeachment case).

153. See 4 ElL.IOT'S DF BAIFS, supra note 151, at 32-34.

154. 4 at. at 35; sep also 4 ud. at 49 (recording Archibald Maclane makms umula comments). 
then how could an ex-officer be impeached? But Johnston's comment seems to be directed more at dispelling the notion that ordinary citizens could be impeached than at discussing the acceptable timing of impeachment trials. Late impeachment does not present the problem of pursuing an individual who "had no office," and thus does not really conflict with Johnston's underlying interpretation. ${ }^{155}$

Finally, another comment at the North Carolina convention further reinforces that impeachment was designed not simply for removal, but as a way of promoting accountability in office. Framer, Ratifier, and later U.S. Supreme Court Justice James Iredell stated:

[Impeachment] will be not only the means of punishing misconduct, but it will prevent misconduct. A man in public office who knows that there is no tribunal to punish him, may: be ready to deviate from his duty; but if he knows there is a tribunal for that purpose, although he may be a man of no principle, the very terror of punishment will perhaps deter him. ${ }^{156}$

Iredell's statement is perhaps the clearest one by a Framer that impeachment is intended as a structural incentive for executive and judicial officials to behave. As will be discussed further below, in the argument from constitutional structure, late impeachment is an important component of this function.' Because the impeachment process is so cumbersome, it is only with late impeachment that the incentive effects of impeachment extend to the later portions of an executive officer's term. Without late impeachment, as Iredell puts it, there is effectively "no tribunal to punish" such a malfeasing officer, who would then be all too "ready' to deviate from his duty." 158

155. Other comments may have reflected views on late impeachment. but not necessarily. See, e.g., 3 id. at 516 (recording James Madison at V'irginia com ention, statung that a criminal President in league with senators would still be vulnerable to impeachment, as one-third of the Senate turned over even (wo vears). It is unclear whether Madison was referring to impeachment after the President's term ended, or simply impeachment during the President's term after new senators were elected.

156. 4 id. at 32 (emphasis added).

157. See infra Part V.A.

158. Although the criminal law provides additional incenures, unpeachment coven offenses that may fall short of criminal wrongdoing or that are too politucal tor the ordinary judicial process to handle appropriatels. Impeachment alse provides 


\section{The Argument from History}

Impeachment in 1787 meant pursuing public offense's committed by public officials. Private citizens were exempt from such inquiries-except to the extent that they had been public offenders who had since left office.

There was clear precedent for late impeachments in Amcrica and an even clearer one in England. Several states made clear that late impeachments were preferred or even required, and no states specifically barred them. If regular impeachments were more common than late impeachments in America, it was only because they were more worthwhile, not because they were the only way to proceed. American impeachment was designed not solely to remove misbehaving officers, but to provide incentive's against their misbehavior in the first place, a goal for which late impeachment provides essential support.

When the Constitution was debated, drafted, and debated again, this tradition of late impeachment was not addressed head on. Several other limits were placed on impeachment, however. Another one-preventing impeachment of the President "whilst in office" and presupposing his late impeachability - was almost adopted as well. But no provision on late impeachment was introduced, suggesting that it was not part of the historical baggage of the word "impeachment" that the Constitution took pains to shed.

\section{TEXT}

The text of the Constitution places several significant limits on the impeachment power, but it neither explicitly authorizes nor explicitly forbids late impeachments. Indeed, read over-literally, it does not even limit impeachment to civil officers, let alone sitting officers. ${ }^{150}$ But regardless of whether impeachment is limited to civil officers or is not limited at all, the text of the Constitution does not foreclose the possibility of late impeachment. The textual argument against late impeachmont is a defensible one, to be sure, but it is not the best interpretation of the text.

punishments that the criminal law does not. Sep infin notes 235 and 271 and accompanying text.

159. For convenience, the term "civil officers" is used here to tefer not fust (1) federal civil officers but also the Vice President and the President. Sep supa note 17. 


\section{A. Everything but Article II, Section t}

The Constitution establishes that the House and Senate have the main responsibility for construing the breadth of their own impeachment powers. They are given the sole powers to impeach $^{160}$ and to try impeachments, ${ }^{101}$ and they are also given the authority to make their own rules for their proceedings. ${ }^{162}$ Because the Constitution commits these matters to their discretion, their determinations generally are not susceptible to judicial review. ${ }^{163}$ Further strengthening Congress's dominion, the President's otherwise plenary power to pardon is void with regard to impeachments. ${ }^{10}$

The Constitution does, however, provide some specific limits on the impeachment power in Article I, Section 3: The Senate must sit on oath or affirmation; the Chief Justice presides when the President is tried; a two-thirds majority is required for conviction; and the outer limit of the Senate's sentence upon conviction is removal plus disqualification from holding office.

160. U.S. CONST. art. I, $\$ 2$, cl. 5.

161. Id. $\$ 3, \mathrm{cl} .6$.

162. Id. $\$ 5$, cl. 2.

163. Nixon v. United States, 506 L'.S. 224, 234 (1993) (-Tr]he Judici.un, and the Supreme Court in particular, were not chosen to have am role in impeachments." ): ver also id. at 253-54 (Souter, J., concurring) ("If the Senate were to . . comuc:[1, vils. upon a coin toss, or upon a summan' determination that an officer of the linted States was simply a 'bad guy,' judicial interference might well be approprnite." (mtern.l quotation marks and citation omitted)).

This is not to say that the House can impeach amone it wants at a whm, 1 smph means that the House is the lead interpreter of the Constitution on this wsuc. Allowing judicial review would not change the standard. it would just add a sifeguturd bs adding another institutional interpreter of the standard. But few besides the comcal would wit that with judicial review the House could impeach ansone that the Supreme (inust wants at to impeach. Just as the Supreme Court would be presumed to appls the iequisite constitutional standard, so too is the House bound bo the Comstutuon. There 1s, of course, a rich literature on the subject of non-judicial constitutuonal meterpretatem ter, e.g., MARK TUSHNET, TAKING THE CONSTITLIION AWl ERON 11 t (d)t RIS (1999): SANFORD LEVINSON, CONSTITLTIONAL. FATII 27-30, 37-50) (1985) (definmg "calholic" and "protestant" approaches to interpretive authority): Neal kuma Kitsal. Ixgrslatrue Constitutional Interpretation, 50 DL KE L.J. 1335 (2001): Michiacl Stohes Patulsen, The . Mast Dangerous Branch: Executive Pouer to Say What the Laut Is. 83 (.to. 1..J. 217 (199.t) But see Larry Alexander \& Frederick Schauer. On Extrajudicial (omststutumal Interprrtutuen, 110 HARV. L. REv. 1359 (1997) (arguing in favor of judicial supremacr).

164. See supra text accompanying note 13; infra text accompumung note 262 But ser Kalt, supra note 13, at 790-93 (postulating other limitations on the pardon pewer)

165. U.S. CONST. art. I, $\$ 3$, cls. 6-7. While removal is mandaton (if applicable) upon contiction, disqualification is not; the ovenwhelmm majont of sentences upen conviction have not included disqualification. See mfra note 522. But ser fon.th.tn 1 urles. Senate Trials and Factional Disputes: Impeachment as a Madeseman Davere 49 D( ht 1..] 1 . i2 n.349 (1999) (contending that "the failure to sech disgualufictuon with at temosal is 
It also provides some limitations elsewhere, in Article II, Section 4 , which will receive separate consideration below. ${ }^{1+1 .}$

Another limit that the Constitution places is that impeachments must be "impeachments," a point that is no less important for being obvious. If the word "impeachment" connotes something limited-i.e., if only certain actions can occur within the true meaning of the word "impeachment"then the reach of the congressional impeachment power is similarly limited. ${ }^{\text {hit }}$

An analogous if extreme example may make this point better. Congress can grant letters of marque and reprisal, ${ }^{1,4}$ but it cannot grant titles of nobility. ${ }^{16.9}$ A letter of marque and reprisal is a document that gives permission to a private citizen to outfit a warship and plunder the ships of foreign enemies. ${ }^{170}$ The Constitution does not offer this definition, but the term "letter of marque and reprisal" had a meaning and a context in 1787 , such that the power granted by the Constitution to Congress in this regard was specific and limited. ${ }^{171}$ Congress cannot simply name you a hereditary Baron, label the appointment a letter of marque and reprisal, and declare that Baron is not a title of nobility. The point is not that the Constitution defines the terms "title of nobility" and "marque and reprisal"-it does not. The

conceptually difficult to understand"). Furthermore, once a tworthusds majonty has been obtained for conviction, only a simple majority is required to disqualuty the defendant.

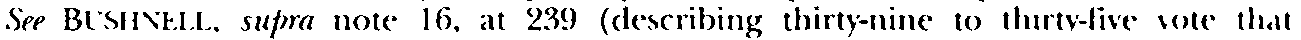

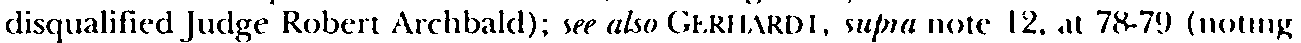
Senate practice of requiring only a majority for clisqualification but agumg that iwothirds should be required).

166. See infra Part IV'.B.

167. See Gibbons v. Ogden, 22 L'.S. (9 Wheat.) 1, 189 ("[O]ur constimtion beng. as was aptly said at the bar, one of enumeration, and not of definition. to dscentum the extent of the power, it becomes necessary to settle the meaning of the word."): Riwit. supra note 35, at 210 ("Impeachments are thus introduced as a known definite term, and we must have recourse to the common law of England for a definition of them."): $1 /$. in/m note 351 and accompanying text. Admittedly, as legal realist and then-House Minomits Leader Gerald Ford put it, an "impeachable offense is whatever a majority of the llouse of Representatives considers to be at a given moment in history." 116 (C)NC. RFt . $11.91 \%$ (1970) (statement of Rep. Ford). But the House (and the Senate) has a duty to root its "considerations" in the Constitution, and historically it has done so.

168. L.S. Co\SI. art. I, $\$ 8, \mathrm{cl} .11$.

169. Id. $\$ 9, \mathrm{cl} .8$.

170. See generally Charles A. Lofgren, War-llakung ('nder the Constututon: The Ongunal L'nderstanding, 81 YALE L.J. 672, 692-96 (1972). But sep generally Jules I.obel, "I, atlle Wius"

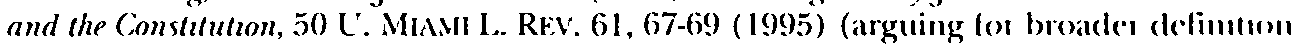
of marque and reprisal as embodving the concept of imperfect war).

171. For those who disfavor looking to the original understandung. "letter of marque" has the same meaning today. See BL. K k's L IW DICI IoNARY 917 (7the ed. 1990) 
point, rather, is that a "letter of marque and reprisal" is what it is and nothing more. The limits of the meaning of the term "marque and reprisal" represent congruent limits on the power actually given to Congress to grant the letters.

There is a sound basis for attributing a limited definition to the word "impeachment" in the United States in 1787, namely; that it comprehended only proceedings concerning public officials' conduct of their jobs. ${ }^{172}$ Put another way, if the House were to try to impeach me, a private citizen, for stealing office supplies from the private law school where I teach, its action would be as void as your baronage. As a House manager put it in an actual late impeachment trial, "[T] he jurisdiction of the Senate by the very naming of impeachment per se is confined to official crimes."173 A congressional prosecution of a pricate citizen simply would not be an "impeachment. ${ }^{\text {"1it }}$

At first glance, the English precedents might seem to suggest otherwise, because English impeachment technically was not limited to public offenses or public offenders. ${ }^{13}$ But the impeachment of peers for private misconduct was based on the fact that the ordinary courts were not equipped to try such significant defendants. ${ }^{176}$ In the United States, with no nobility, this form of impeachment did not translate. As for the impeachment of commoners, in practice this at least was limited to state offenses-the domain of Parliament-and had in any case fallen into desuetude long before $1787^{17}$

Though English impeachment evolved to include these limits, American impeachment included them all along. Private citizens were pursued through the regular criminal process or through attainder, but not through impeachment. ${ }^{130}$ W'hen the newly independent states wrote their constitutions, they made

172. "Impeachment" certainly had such a limited comnotation once the Constitution became well established. but this simpls reflects the mfluence of subsequent interpretation, a sort of textual bootstrap that does not advance this argument. See, e.g., State v. Hill, 55 N.W. 794, 796 (Neb. 1893) ("Here none but public officers are subject to impeachment."); 2 STORY, supra note 42 , at 2333 ("The offences, to which the power of impeachment has been, and is ordinarilv applied. at a remed. are of a political character.").

173. BELKNAP TRIAL, supra note 18 , at 54 .

174. This is so regardless of what Article II. $\$$ t has to sin about who can be impeached and for what. See infra Part IV.B.

175. See supra text accompanying note 38 .

176. See supra text accompanying note 40.

177. See supra note 47 and accompanying lext.

178. See supra text accompanying note 61 . 
this limitation on impeachment clear. ${ }^{174}$ The single exception to this was that former public officials-technically private citisens at the time of trial-were impeached for prior public actions. ${ }^{\text {INI }}$ By 1787, then, "impeachment" had come to mean a process for the legislature to inquire into and prosecute public offenses committed by public officials.

If the federal constitutional provisions on impeachment discussed above had been the only ones written into the federal Constitution, it would be much clearer that late impeachment is allowed. Even those who adhere to a wholly literalist reading of the Constitution devoid of context would concede that, other than explicit limits specified in the text, the congressional impeachment power is as broad as the word "impeachment" itself. While the definition of impeachment can be restricted to exclude private offenses and private offenders, there is nothing inherent in the notion of impeachment that requires the process to begin or conclude while the defendant is still a public official.

\section{B. Article II, Section 4}

There is, of course, one other significant clausc on impeachment in the Constitution, Article II, Section 4: "The President, Vice President and all civil Officers of the United States, shall be removed from Office on Impeachment for, and Conviction of, Treason, Bribery, or other high Crimes and Misdemeanors." ${ }^{\text {"1s1 }}$ This clause has been interpreted fairly decisively as limiting the impeachment power further, so that it reaches only civil officers and only high crimes and misdemeanors. Because some have construed the limitation to "civil officers" additionally as restricting the timing of impeachment, Article II, Section 4, plays a uniquely important part in the interpretation of late impeachment.

1. The Over-Literal Reading: Helpful but Wrong

This limiting construction is not the only one possible for Article II, Section 4. Another reading of the provision-which I will concede has been soundly rejected, even though it would

179. See supra Part III.B.2.

180. See supra text accompanying notes 66-69.

181. U.S. Co\s1.ant. II. $\$ 4$. 
make the case for late impeachment a slam dunk-is the overliteral one. Under this reading:

The Constitution does not undertake to define the nature and form of impeachment, or its scope and boundaries.... [T] he House of Representatives may impeach for other offenses, abuses, failures, and wrongs than those included in the terms "treason, bribery, and other high crimes and misdemeanors." [I]t may impeach other parties than the "President, Vice President, and other civil officers of the United States. ${ }^{\text {.182 }}$

The basis of this argument is that Article II, Section 4 provides on its face only a mandatory sentence: if a civil officer is impeached and convicted of a high crime or misdemeanor, he must be removed. It does not say that only civil officers can be impeached. It does not say that impeachment can only be for high crimes or misdemeanors. It says one thing, and one thing alone: if the party is a civil officer, and if the charge is a high crime or misdemeanor, then conviction requires removal. In other words, Congress can aiso pursue non-officers, non-high crimes, or both at once, and can either remove the convict in such cases or not. Under such a limited interpretation of Article II, Section 4, late impeachment is obviously within the power of Congress-as is the impeachment of jaywalkers or family pets. ${ }^{\text {"ss }}$

Such an approach-parsing the text of a clause in isolation from the rest of the Constitution, oblivious to the general context and larger structure of the document-commits the error described by Laurence Tribe as mistaking a gap in a map for a hole in the space it describes. ${ }^{\text {nt }}$ Impeachment has a context and a meaning deeper than that yielded by wooden, out-of-context readings of constitutional clauses. A better practice is to reason based on broader textual clues, structure,

182. BELKNAP TRLAL, supra note 18 , at 146 (opinion of Senator hes).

183. This debate most recenty erupted over the Clinton impeachment, in wheh some commentators argued that impeachment need not be for high enmes and misdemeanors. E.g., Joseph Isenbergh, Impreachment and Presudental lmmumth from Judtcual Process, 29 YALE L. \& POL'Y REv. 53, 62-77 (1999) (arguing that Article II. $\$$ id does not define impeachable offenses, but merely requires the remonal from office of the stated class upon conviction of various serious offenses). Those who tooh a lews literal wew of Article II, Section 4, such as Professor Akhil Amar, offered the "janwalhung" seenuno ats rebuttal. Akhil Reed Amar, On Impeaching Presidents, 28 Hofstka 1.. R5x. 291. 323 (1999). For his part, Isenbergh argued that impeachment would be limited to those crumusl offenses that were historically the subject of impeachment. Isenixergh, supra, at $y_{7}$

184. Laurence Tribe, Taking Text and Structure Senously: Reflectuons on Firrtionn . Methot in Constitutional Interpretation, $108 \mathrm{HARV}$. L. REV. 1221, 1239-45 (1995). 
context, and history and to deduce what must fill the space that the map has failed to describe.

To be fair, the over-literalist argument sketched out above is something of a straw man (with due respect intended to those who actually subscribe to it) constructed by those who oppose late impeachment. Such opponents have argued that if Article II, Section 4 allowed for late impeachment, it would not offer any limits at all on impeachment; therefore, late impeachment must not be allowed. ${ }^{18.5}$ But this syllogism is not valid. Even if Article II, Section 4 does not limit impeachment to civil officers, neither does it authorize Congress to impeach offenders who never served in office. As discussed above, the impeachment power is inherently limited by the bounds of the definition of the term "impeachment" itself, and these bounds do not include impeaching wholly private citizens. ${ }^{18 t}$ They do, however, include late impeachment.

Therefore, while the over-literalist argument is too unpopular an interpretation on which to rest the case for late impeachment, one should reject the reductio ad absurdum argument leveled against it by the opponents of late impeachment. The parade of horribles marshaled by the overliteralists is in reality a short one, including as potential additional targets for impeachment only members of Congress and perhaps state officials but not people who have never been in office. There are structural and precedential reasons (o) exclude members of Congress and state officials from the domain of federal impeachment; ${ }^{187}$ moreover, one who starts with the literalist reading but is not averse to using other interpretive tools can limit impeachment to "civil officers" without using Article II, Section 4 and without implying a limitation on the timing of proceedings that would exclude late impeachment. ${ }^{188}$

185. See supra text accompanying note 23.

186. See supra text accompanying notes $167-80$.

187. Although the federal Constitution does constrain state officials as well a federal ones, these constraints are few and very specific (e.g., the limms on state governments in Article I, $\$ 10$; the oath requirement in Article V1. \$ 3). Regaldung members of Congress, see infra note 197.

188. A lingering problem with such a reading is that it would not limit imperachable offenses to high crimes and misdemeanors. To be sure, this is not wholly umicasmable. given the implication in Article III, $\$ 1$ that judges can be impeached for mete lapses $m$ "behavior" that fall short of high misdemeanors. Congress has seemed to apply this lowes 


\section{The Expressio Unius Reading: Four Possible Interpretations}

In any case, Article II, Section 4 does limit impeachment to civil officers. ${ }^{159}$ More precisely, it has been used to limit impeachment to civil officers. The over-literalists are correct that there are no explicit limits in the text, and their critics are often guilty of citing Article II, Section 4 as if the text clearly says something that it does not. ${ }^{190}$ The limiting effect of Article II, Section 4 is based on one of two contemporaneous understandings of the clause, which was subsequently adopted by Congress and scholars. ${ }^{191}$ This understanding takes Article II, Section 4 as a sort of expressio unius ${ }^{\text {ing }}$ description of impeachment that mentions who can be impeached and for what, and that implicitly excludes any' other subjects not listed. ${ }^{195}$ Congress's very first impeachment case reached this issue, ${ }^{1,4}$ and with the passage of years it has largely become settled," though

standard to judges, though it has purported to use the "high crimes and mbxiemeanors" standard in each case. See infra note 198.

189. The Blount case is taken as setting this matter. See mfra note 300; ser abo ? STORY, supra note 42, at 257-64 (noting Blount precedent and declanng that impeachment is limited to civil officers and high crimes and misdemeanors).

The term "civil officer" is used here to include the President and Vice Prestdent. Sex supra note 17.

190. See, e.g., Ronald D. Rotunda, An Essay on the Consthtutunat Parameters of Federal Impeachment, $76 \mathrm{Ky}$. L.J. 707, 715 \& n.37 (1988) (citing only Article $11 . \$$ \& for proposition that " $[t]$ he Constitution limits the impeachment power to all civil Omicers of the L'nted States"); 2 STORY, supra note 42, at 255-57 (discussing same).

191. James Wilson, Framer and original Supreme Court Jusuce, adsanced the interpretation. 1 JAMES W'ILSON, supra note 43 , at 426 ("In the l'nted States. . impeachments are confined to political characters, to political crimes and misdemeanors, and to political punishments. The president, vice president, and all cml officers of the United States . . . are liable to impeachment . . . ). Profesesr Akhul Reed Amar surveys this and other similar statements br Framers and the schulark consensus in Amar, supra note 183, at 333-34.

192. The full phrase is expressio umus est exclusio alternus to expliculs menton one thing is to (implicitly) exclude others.

193. Amar, supra note 183, at 332 ("[T]he mainstream tiew holds that (b) expressto unius) Article II protects private citizens from impeachment: and here Arucle II has worked perfectly, confirming many Founding statements that impeachment was lumted to "officers." ).

194. See infra Part VI.A.1.

195. See supra note 189. 
some scholars still disagree, ${ }^{[m,}$ and others offer a few subtle distinctions. ${ }^{19 \pi}$

The expressio unius view further notes that Article II, Section 4's discussion of impeachment-covering civil officers who commit high crimes and misdemeanors, and who are removed if convicted-is the only place that the Constitution addresses

196. For an entertaining exchange on the subject-not limited to discussion of who can be impeached but also for what they can be impeached-see the exchange between Protessor Akhil Reed Amar of Yale Law School and Stuart I'aylon fr. of the National Journal in Amar, supra note 183, at 317-41.

197. My own view of impeachability and the definition of impeachable offense's is that $\$ 4$ gives the impeachment standard only for executuve officers and leaves removil in the legislative and judicial branches to the Expulsion and Cood Behavior (ilatuses respectively. See U.S. CoNSr. art. I, \$5, cl. 2; ul. at art. III. \$ 1.

This view of Article II, \$4 makes the following textual and structural case: (iongress can pursue any public offense by a public official; anything else would not be all "impeachment." Sep supra note 167 and accompanying text. There are three types of officials that might be subject to this sort of assault: legislative, executive. and fuclic tal

I.egislative officials are subject to expulsion, not impeachment, but the make semse given that (1) expulsion is specified in the (onstitution, U.S. (ONSI. art. 1. \$5. (1. 2: (2) expulsion requires a two-thirds vote in the expelling house, which reptesents a slights different, but not appreciably lower consensus than impeachment, see ad: and (3) while the punishment via expulsion is more limited than that for impeachment. there is a sound basis for distinguishing between single elected officials in large legislative bodres on the one hand and lifetime-appointed judges, un-elected executive officers, and the nationally powerful President and v'ice President on the other hand. Sep (ir kINRII. supra note 12, at 75-77 (discussing textual and structural arguments aganst lhe impeachability of members of Congress): of. A Native of Virginia (James Momoe).

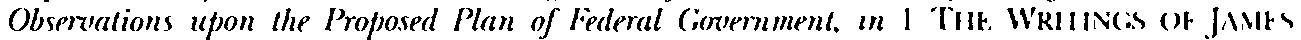
MONROt (Stanislaus Murray Hamilton ed., New York, (;.P. Putnam's Som I8!98). available at http://press-pubs.uchicago.edu/founders/documents/a1_2_isl2.htul ("The Senators having a power over their own members, have the right of expulswl. Why then should they be impeachable?").

Executive officials are subject to impeachment as described in Article II, $\$$. The President, Vice President, and the non-elected, non-military officers of the executise branch can be impeached for high crimes and misdemeanors. If they ane convicted. thes are removed and possibly disqualified from future service as well. Although $\$$ ilpesus only to require a certain punishment upon a certain type of conviction, the alten native is a complete lack of standards, and so an expresso unutus reading of this clatuse is appropriate. Article II, $\$ 4$ is meant to constrain not just the executive offic ess subject to it but the Congress applying it as well.

Judges (and here is where this interpretation deffers from the one descibed in the main text) are subject to impeachment not just for high crimes and misdemeduots, but also for misbehavior. U.S. CoNSr. art. III, \$ 1 . Because executive officials serve fot limited terms, it makes sense to have a higher threshold for removal than judges. who would otherwise not be removable for, say, chronic drunkenness. Indeed, impeac hment has touched such private misconduct. See, P.g., infra Part VI.A.4 (describing case of Juclge Delahay, a reputed drunk): VAN TASSEI, \& FIVKEL.MIN, supra note 1, at 91-(5) (descubung case of Judge John Pickering, convicted for "total intoxication" among othet thung) Although the Senate has purported to apply the same standard of high crimes and misdemeanors to judges. and many commentators believe that the high crimes/misbehavior distinction is not constututionally significant, it is clean that fuclges have faced a lower threshold. Spe infra note 198. 
such issues of scope. Therefore, this must be all there is. "'an a sense, this reading views the silence about the scope of impeachment as implicitly adding the words "The only way that impeachments go is that..." before "[t]he President, Vice President and all civil Officers of the United States, [are] removed from Office on Impeachment for, and Conviction of, Treason, Bribery, or other high Crimes and Misdemeanors." It is of no moment that Article II, Section 4 only purports to provide a mandatory punishment and that it is set apart from the provisions in Article I that spell out and limit congressional impeachment power. ${ }^{1.9}$

But let's get to the point. Even if this is "all there is" in the text - that is, that impeachment only applies to "civil officers" what does that necessarily tell us about the timing of impeachment? Very little. Indeed, it not only tells us very little about the timing of the trial, it also says nothing about the timing of the offense. Thus, there are four possible versions of the scope of impeachment within the expressio unius reading:

198. See BELkNAP TRIAL, supra note 18. at 98 (opinion of Sentitor Howe) (-[W]e have not a suggestion as to who may be impeached. I muself find that in the fouth section, second article, and I can find it nowhere else."); w. at 123 (opimon of Sendtor McMillan).

Federal judges are also impliedly impeachable for misbehatior, wheh eems tw undermine this reading of the clause as exclusive. This is especialls so guen that judges are civil officers. See U.S. CONST. art. II, \$2, cl. 2 (stating that the President sh.dll appoint . . . Judges of the supreme Court, and all other Officers of the ('mted Stutes") (emphasis added); id. at art. III, $\$ 1$ ("The Judges, both of the supreme and mienur Courts, shall hold their Offices during good Behaviour.....) (emphasss added). Congress has not invoked the Good Behavior Clause, and his purported to spph the single standard of Article II, $\$ 4$ to judges.

Many commentators believe that there is one unified standard. See, e.g. (it Rlikl)t. supra note 12, at 83-86 (discussing this tiew): Jeff Sessions \& Andrew Sigles, Judurut

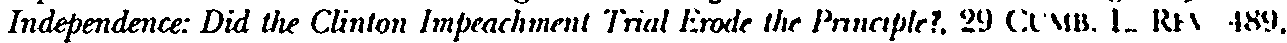
512 (1999) (citing consensus, including Justice Storv): (ivss Sunstem,. Impracheng the President, 147 U. PA. L. REv. 279, 304 (1998) ("I do not believe that this . atgumetut is convincing. Judges may not be removed from office for bad behastor: thet mas be removed only for high crimes and misdemeanors."). Others do not. See, ( $\mathrm{g}$. Br R(, k. supra note 29, at 122-80 (arguing for separate judicial removal stand.ud): . Im.tr, supre note 183, at 327 (expressing belief in separate standards and noting that $-[t]$ houghtut scholars are not of one mind on this point").

Either way, judges have undoubtedly been held to a lower standarel. See lil I tust I \& FINKELMAN, supra note 1, at 8: Sunstein, supra, at 30-4 (-111]iston has unambuguetshs converged on the judgment that there is a lower threshold for judges than for presidents."). Given this historical reality, and given the mxed consemsus among commentators, it is reasonable to conclude that judges are indeed held to a lowet standard.

199. See supra note 90. 
1. "Civil officer" limits the timing of both the offense and the trial. A person can only be impeached if he was a civil officer when he committed the offense and if he is currently a civil officer. ${ }^{200}$ (This "conservative" view describes every convicted impeachment defendant to date.)

2. "Civil officer" limits the timing of the offense but not the trial. A person can be impeached at any time, as long as he wals a civil officer when he committed his offense. (The "late impeachment" view.)

3. "Civil officer" limits the timing of the trial but not the offense. A person can be impeached regardless of when the offense was committed, as long as he is currently a civil officer. (The Clinton/"Whitewater" view, or, in the spirit of bipartisanship, the Bush/"Iran-Contra" view.)

4. "Civil officer" limits neither the timing of the offense nor the trial. A person can be impeached at any time, regardless of when his offense was committed, as long as he was a civil officer at some point in his life. (The "radical" view.)

This breakdown can be placed in a two-by-two chart:

Must the party presently be in office?

\begin{tabular}{l|l|l|l|}
\cline { 2 - 3 } \multicolumn{1}{l}{} & \multicolumn{1}{c|}{ Yes } & \multicolumn{1}{c|}{$N_{0}$} \\
\cline { 2 - 4 } Must the offense have occurred & Yes & 1 (conservative) & 2 (late) \\
\cline { 2 - 4 } while the offender was in office? & No & 3 (Whitervaler) & 4 (radical) \\
\cline { 2 - 4 } & &
\end{tabular}

Interpretation \#4, the radical version of late impeachment, is immediately problematic. It eviscerates the limitations inherent in the word "impeachment," because it allows people to be impeached who not only committed offenses wholly unconnected with their service, but who are not currently serving in any office. By using the term "officer" neither as a basis to define the offense nor as a basis to define the defendant in any relevant way, \#4 expands impeachment beyond all reasonable compass. It renders the use of the term "officer" an illogical and arbitrary formalism.

The principal benefit of Interpretation \#2 is that, by basing congressional jurisdiction on the status of the offender at the time of the offense, it reinforces the notion that "impeachment" for "high crimes and misdemeanors" is limited to offense's

200. This view possibly could be divided into two separate variants. The office in which the suspect committed the offense mas or may not be the same as the office in which the suspect is currently serving. This issue is discussed further below, in P.at V.I 
committed by public officers qua public officers. ${ }^{\text {ind }}$ In other words, if impeachment is supposed to be about offenses that, as The Federalist put it, "proceed from the misconduct of public men ... [and] may with peculiar propriety be denominated POLITICAL," ${ }^{, 02}$ it only makes sense that the term "civil officers" refers to the offender at the time of the offense, regardless of what has happened to him in the lengthy interim of discovery, accusation, debate, impeachment, more debate, and conviction. Indeed, this is the clear scope of the impeachment powers specified in the state constitutions written before $1787 .^{\text {sus }}$ It also tracks the way English impeachment was timed, which is significant given the textual fact that the Framers explicitly changed the rules where they found English practice unsuitable - and they made no such explicit change with regard to the timing of trials. ${ }^{204}$

The principal defects in \#2 are that it makes the term "civil officer" appear to apply to people who are no longer civil officers and that it may moot Article II, Section f's mention of removal by applying to people who have no office from which to be removed. But removal is just a penalty on conviction-if applicable-and does not purport to be a further description of who is impeachable. Put another way, the removal requirement is a check on officers, not a protection for them. Noreover, removal is not the only penalty facing the target of an impeachment. ${ }^{205}$

Criminal statutes that specify penalties in similar ways generally are interpreted this way; thus, the Constitution should be also. ${ }^{206}$ To take just one example, the federal statute on bribing agricultural inspectors specifies:

201. See BELkNAP TRIAL, supra note 18, at 154 (opinion of Senator herman) (asserting similar argument).

202. THE FEDERALIST NO. 65, at 396 (Alexander Hamilon) (Cinton Rosster cd.. 1961); see also supra note 191 (reporting similar comment from James Wilson).

203. See supra Part III.B.2.

204. See supra note 142 and accompanying text.

205. See infra Part V.B and VIII.A (discussing disqualification pentalu) and Patr VIII.B (discussing possibility of other penalties).

206. See, e.g., BELKVAP TRIAL, supra note 18, at 148 (opimon of Sentutu Dawes) (citing embezzling statutes forbidding certain conduct b "officers"): ud. at 15.4 (opmum of Senator Kernan) (citing statute protiding that "everv officer" commutung certann crimes "shall, upon conviction, be removed from office and forever theteafter be incapable of holding any office under the L'nited States"); ud. at $36-4$ (opinton of Senator Wadleigh) (arguing that "such a construction would be absurd" if applied to such statutes). 
[A]ny inspector ... or other officer or employee of the United States . . . who shall receive . . . any gift, money, or other thing of value ... shall be deemed guilty of a felony and shall, upon conviction thereof, be summarily discharged from office and shall be punished by a fine . . and by imprisonment not less than one year nor more than three years. ${ }^{20 \overline{7}}$

Few people would read this statute and conclude that because it mentions only current employees and officers, and because it specifies removal from office as a mandatory punishment, that one who has left office cannot be prosecuted under this provision. Indeed, former Secretary of Agriculture Mike Espy was indicted under this statute three years after leaving office. ${ }^{210}$ Although Espy was eventually acquitted, it was not because he had already left office; his trial proceeded to the merits. ${ }^{2(t)}$

Another constitutional provision presents a similar interpretive challenge-and has been read the same way by Congress. Article I, Section 5, Clause 2 provides: "Each Housc may ... punish its Members for disorderly Behaviour, and, with the Concurrence of two thirds, expel a Member." Congress has used this power to discipline members who have already left office. ${ }^{211}$

Interpretation \#3 has textual appeal ("officers" are "officers," and ex-officers are not), as well as an admitted degree of coherence. Playing off of the reference in Article II, Section 4 to removal, it focuses on the fact that only current officers can bc turned out of office. If they are already gone from office, the Removal Clause is rendered mere surplusage. ${ }^{21 "}$ Under this view.

207. 21 L'.S.C. $\$ 622(1994)$.

208. Bill Miller, Espy Arquatted in Gifts Ciase, Wishi. POSI, Dec 3. 19098, at 11 (summariring chronology of Espy case).

209. Lnited States v. Espv, 145 F.3d 1369, 1371 (D.C. (air. 1998) (attachung no leg.al significance to fact that "Espy is not subject to temoval because he is no longer Secretus of Agriculture"): Miller, supra note 208.

210. L.S. CoNst art. I. \$. .. cl. 2.

211. See infra Part VI.A.3 (discussing cases of Representatues Whutemone and Deweese).

212. Sep, e.g. 14 ANM US OF CONC. 430-31 (1805) (speech of Luther Maum in impeachment tral of Justice Samuel (Chase) ("The President, Vice President, and othen cival officers can only be impeached. ... In the first auticle, sectuon the thucl, of the Constitution, it is declared that, judgment in all cases of mpeachment. shall not extend further than removal from office, and disqualitication to hold any office of honon, must. or profit. under the United States. This clearls evinces, that no persons but those who hold offices are liable to impeachment."): infra text accompanving note 355 ( argument made in Belknap late impeachment (ase): Souss, supa note 16. 
impeachment is less about trying a certain kind of offense than it is about keeping a certain kind of person out of office. ${ }^{313} \mathrm{An}$ officer who committed a high crime and left office would face impeachment only if he returned to office. The same would be true if he committed the high crime as a private citizen (after all, the two examples of high crimes in the Constitutiontreason and bribery-are both offenses that can be committed by private citizens).

Despite its coherence, Interpretation \#3 tries to make Article II, Section 4 do too much work. Is the mention of removal meant to restrict the result of impeachment-and thereby the timing of impeachment trials-or is it just meant to limit the terms of malfeasing civil officers who would otherwise serve for fixed terms (the President and Vice President), at the pleasure of the President (executive civil officers), or for life (judges)? If removal were the only possible judgment in impeachment cases, the former interpretation would be more likely. But removal is not the only possible judgment mentioned in the text; disqualification is possible too. ${ }^{1 / 4}$ Removal is a mandatory sentence for sitting officers upon conviction, but it is not the sole end of impeachment. While the other parts of Article II, Section 4 look backward to precedent conditions for impeachment, removal looks forward to its results. Thus Article II, Section 4 says "removal requires conviction" and even that "conviction guarantees removal," but it does not clearly or necessarily say "impeachability equals removability." In sum, Interpretation \#3 is a relatively plausible textual reading of Article II, Section 4, but it is not the only possible one, and it has deep flaws.

Interpretation \#1 has some benefits of both \#3 and \#2. It takes full stock of the word "officer" and the removal provision, but it also dovetails with the contextual notion that impeachment is to be directed at public officials qua public officials. However, \#1 also suffers a drawback of \#3, in that it reads too much into the removal provision. Moreover, it opens up a potential textual

213. An excellent piece of evidence that this is not the true moanmg of impeachment is the simple fact that late impeachment was practiced in Englind and the states in the years before the drafting of the Constitution. This is more a histoncal pont than a textual one, though. See supra Part III.A (English precedent): Part III.B.1 (state precedent).

214. U.S. CONST. art. I, $\$ 3, \mathrm{cl}$. 7 . The possibilitv of other punishments is descussed in Part VIII.B, infra. 
dilemma: Can an officer be impeached in a second office for something he did in a prior office? To the extent that such an officer is impeachable, it becomes less tenable to distinguish between Interpretations \#1, \#2, and \#3. In all, though, Interpretation \#1 is a plausible one as a matter of pure text. As discussed in detail below, however, it has significant flaws in the realms of structure and precedent. ${ }^{25}$ Additionally, similar provisions in state constitutions have not been held to limit impeachment to sitting officers. ${ }^{210}$

\section{Conclusion}

It is easy to argue that if the Constitution meant to allow late impeachment, it would have made that point much more clearly. ${ }^{217}$ On the other hand, the same can be said about precluding late impeachment. If one were to focus solely on the text of the Constitution's impeachment provisions-ignoring their history, structure, and precedents-one could best conclude that impeachment may reach public misconduct by civil officers who have left office. But one could also reasonably conclude that impeachment can reach only sitting civil officers. Because the text of the Constitution does not clearly and directly address the proper timing of impeachment, it is necessary to consult history, structure, and precedent 10 address the question of late impeachment. Indeed, it is only by consulting history, structure, and precedent that one can definitively conclude that Article II, Section 4 limits impeachment to civil officers in the first place.

\section{STRL'C:TLRE}

While the plain text of the Constitution's impeachment provisions does not provide a complete solution to the purale of late impeachment, the larger structure of the document-its internal consistency and its recurrent themes ${ }^{21 x}$ - provides much more fodder for discussion. The Constitution's structure reveals

215. See mfra Part V.E (structure); Part L'l.A (precedent).

216. See infra text accompanying notes 448.52 .

217. Vermont (supra text accompanying note 83) and New Jerses (enfra note 111) currently have language that makes late impeachability explictt.

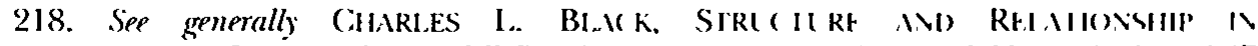
CONSTITL TIONAL. LAW (1969); Akhil Reed Amar. Intratextualusm. 112 HARL. L. RHN 717 (1999). 
that late impeachment is the only way to avoid several incongruous, untenable, and/or presumptively undesired consequences. Although there are some structural arguments against late impeachment, they are outweighed by the ones in its favor.

\section{A. The Deterrent Effect of Impeachment}

Impeachment is a part of the larger constitutional structure of checks and balances. When impeachment came back into vogue in England during the seventeenth century, it was as a means for the legislature (Parliament) to scrutinize and rein in the executive (the King and his ministers). ${ }^{34}$ W'hen the states wrote their first constitutions, having just fought a revolution against overweening executive power, they almost all included similar impeachment provisions. ${ }^{200}$ By the time of the constitutional convention, overweening legislative power was the principal concern. ${ }^{291}$ While impeachment was included in the Constitution from the outset of the debates, there was intensive discussion over whether the President should be impeachable while in office. ${ }^{292}$ Nevertheless, the final document contained a strong impeachment provision that kept the executive and judicial branches under the watchful eye of Congress.

With impeachment, then, the Constitution provided "a bridle in the hands of the legislative body upon the executive [and judicial] servants of the government. ${ }^{\text {nezs }}$ Not only can Congress truncate the otherwise fixed terms of the President and Vice President and the life terms of judges, it can banish executive officers out from under the President. The President can protect his minions from criminal prosecution with a pardon, but he can do nothing to prevent or undo their impeachment. Moreover, the President cannot remove the Vice President or any judges, and some early interpreters argued that nothing in the Constitution even guaranteed him the power to remove his appointees unilaterally. ${ }^{294}$ In a structural sense, early removal is

219. See supra text accompanying notes $35-37$.

220. See supra text accompanying note 71 .

221. See supra text accompanying note 109.

222. See supra Part III.C.1.b.

223. THE FEDERALIST No. 65, at 397 (Alexander Hamilton) (Clinton Rossiter ed., 1961).

224. Alexander Hamilton, no shrinking violet when it came to constnung executwe powers, wrote in The Federalist that presidents could not remove appouters whout 
the province of Congress as much as, if not more than, that of the executive.

But what is the purpose of this check? Is it to get rid of malfeasing officers? Or is it to prevent them from malfeasance in the first place? To some degree it is both, of course, ${ }^{223}$ but from the standpoint of constructing a government of laws and not men, the system of checks and balances seems more directed at "prevent[ing] corruption and tyranny" place than it is at retrospective punishment. As The Federalist put it: "[S]o far as the fear of punishment and disgrace can operate, that motive to good behavior is amply afforded by the article on the subject of impeachments."

Consider this analogy. Is the true power of the requirement of Senate confirmation that the Senate can reject nominees it does not like-a power it uses infrequently-or that it forces the President to not nominate unacceptable people in the first place? Imagine the sorts of appointments to high office that Presidents would make if Senate approval were not required. Unless one believes that appointments would be the same with or without the requirement of Senate approval, the incentive effect of this check and balance is obvious. ${ }^{22}$

This pattern is even more true of impeachment. Impeachment is tremendously cumbersome, and the Senate has not shown much interest in convicting any but the most obviously guilty offenders. There have only been seventeen impeachments-about one every thirteen years on averageand only seven convictions, all in cases of judges. ${ }^{2{ }^{24}}$ There have

Senate approval. Id. No. 77, at 459 (Alexander Hamilton) (Clinton Rossiter ed.. 1961). It was only after a lengthy debate in the First Congress-which included numeous Framers-that the President was given the legzslative atuthority to remove calmenet offic eis. 1 Axisas of Covc. $383-99$ (1789).

225. Jonathan Turley, Congress as (irand Jun: The Role of the Housp of Representatiwes in

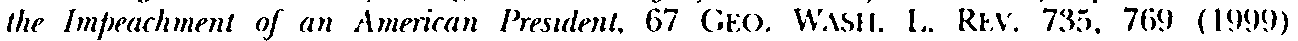
("[I]mpeachment emerged from the Constitutional Convention as a chech and deterrent.") (emphasis added).

226. VAN TASSEL \& FINKELMAN, supra note 1 , at 3.

227. THF FEDERALIST No. 64, at 396 (John Jay) (Clinton Rossiter edl., 1961).

228. Co. Ahhil Reed Amar, The Two-Tiered Strurture of the Juderian Art of 178\%. 1381 '. PA. L. REx. 1499, 1500 \& $n .3$ (1990) (making same point regarding the Prestelent's velo power, and noting that "[t]he framers well understood this political science law of anticipated response").

229. Even these seven convictions did not spare the Republic from any dire halud. As Raoul Berger once put it, "Once employed to topple [Einglish] glant_-Siralford. Clarendon, Hastings-impeachment has sunk in this country to the ouster of dican little judges for squalid misconduct." BERG,ER, supra note 29, at 3. 
been more cases of resignation in the face of possible impeachment then there have been actual cases of impeachment. ${ }^{230}$ More to the point, there likely have been countless high crimes and misdemeanors that were never committed in the first place because of the mere possibility of impeachment. Imagine a United States in which the President knew that no matter what he did, he would be able to remain in office for four years. Can anyone doubt that the temptation to abuse power-particularly to get reelected-would not have occurred more often in such a system than it has in our real one?

No executive officer has ever been remored from office through impeachment, but every executive officer has been constrained by the possibility of it. By the same token, late impeachment may rarely be worth pursuing in fact, but its presence may nevertheless represent an effective way to deter officeholders from malfeasance.

Even in actual cases of its application, the purpose of the impeachment power is broader than removal of particular officers; it has the loftier goal of causing better administration by promoting ultimate accountability. In the words of one commentator:

The only things that can be done-and the things that must be done if the abuse of power is not to become a precedent for subsequent and perhaps even graver abuses and usurpations-is to render the perpetrator incapable of further wrongdoing and to make his punishment serve as a warning to his successors. Impeachment serves the latter purpose fully as much as the former . . . . ${ }^{231}$

Late impeachment is an important contributor to these aims, and barring late impeachment would undermine them." If impeachment cannot touch an officer once he has left office, then it provides significantly less incentive for the officer to

230. See infra note 411 .

231. Bestor, supra note 133, at 277. Even opponents of late impeachment hase noted strongly that impeachment is a "curb upon the exercise of power in the pensenson of those subject to impeachment." BEL.KNAP TRlal. supna note is, at 40 (iccording argument of defense counsel in late impeachment case).

232. The deterrent effect is discussed in this Part; the mcapactutung cflect is discussed in the next. See infra Part V.B. The deterrent pomt was mude clearls win the Belknap case. See infra note 353 (examples from Belhnap (nal) and tevt accompamum notes 379-81. 
behave. More precisely, it provides an incentive for him to behave only early in his term, to conceal his wrongdoing long enough to run out the clock, and to skip out of office if congressional action becomes a serious issue. ${ }^{2 \$ 3}$ By contrast, if he is amenable to impeachment and disqualification for the rest of his days, an officer will have an added incentive to conduct himself appropriately to the very end of his term. To the extent that he does not conduct himself properly, it will at least be harder for him to escape scrutiny forever, as elections intervene and seats in Congress change hands. This accountability will provide some deterrence to others, if not the officer himsclf.

To be sure, many impeachable offenses can be pursued in parallel as criminal offenses in ordinary courts, and ex-officers still must contend with those potential sanctions. But those sanctions exist when the officers are still in office too." And impeachment reaches offenses and provides punishment that the criminal process does not or cannot. ${ }^{2 * ;}$ Barring late impeachment does not increase the effect of criminal sanctions as a deterrent; it merely limits the effect of impeachment as a deterrent.

On another note, criminal sanctions provide a keen analogy to the deterrent effect of impeachment. Imagine a larceny statute that allows a sentence of restitution and jail time. Imagine now that a defendant can terminate the criminal proceeding entirely by returning the stolen money. No thic would ever face jail time, because he could simply pay restitution if and when he was caught and preempt the proceedings. Imagine further that the statute of limitations in this larceny statute was very short, or better yet that it expired at a set date

233. Sep BeLkNAP TRIAL, supa note 18, at 129 (opinion of Senatos Bavatel) ("1lue train could be laid and the slow-match lighted with close calculation, and the mo endiny retire to the place of safety outside the jurisdiction charged with his pumshment.")

234. Rawt., supra note 35, at 215 ("IT) precluded, either before or after an mpeachment, from taking cognuance of the public and official delinquency."). But sep Akhil Reed Amar \& Brian (: Kalt. The Presulentul Prnzlege Aganst Prosecution, 2 NExt's 11 (1997) (arguing that presidents ane mmume from criminal prosecution while in office).

235. See Riwle, supra note 35, at 211 ("[P]olitical offences. . . would be ditlicult to take cognizance of in the ordinary course of judicial proceedings."): al. at 217 ("I I |he" sentence which this court is authorized to impose camnot regularly be promoumced by the courts of law."). For more on this point. see infra note 274 and accompanving ley (discussing impeachment cases that criminal law will not reach), and notes 244 and ill) (discussing criminal statutes that prescribe removal and disqualification as potential punishment and constitutional problems with them). 
every four years. The incentive not to steal would shrink to tero as the limitation date approached. Only the meekest of thieves would be deterred by such a statute. But this is just the sort of incentive structure that impeachment would be limited to if late impeachment were not permitted.

\section{B. Removal, Disqualification, and Mootness}

If one believes that the central purpose of impeachment is removal of the offender, it would follow that late impeachment is not necessary to protect the deterrent effect of impeachment. Returning to the larceny example in the previous Part, if the only sentence for convicted thieves were restitution, it would be no great tragedy if a thief could preempt a prosecution against him by making restitution. Similarly, if the main idea of impeachment is removal, what difference does it make whether the officer leaves office through impeachment, resignation, removal by the President, or expiration of his term? A member of Congress can resign to avoid expulsion, and no one quarrels with that. ${ }^{236}$ If Congress can force someone from office with the threat of impeachment instead of having to perform an actual cumbersome impeachment and trial, that is a good thing. ${ }^{.35}$

This point, true as far as it goes, overlooks the significance of disqualification (not to mention other possible consequences of impeachment). ${ }^{238}$ The addition to the Constitution of disqualification as a possible penalty was not a throwaway." All but one of the pre-1787 state constitutions that specified

236. See BELkNAP TRIAL, supra note 18, at 131 (opinion of Sentitor Boutwell) (making same point).

237. See Firmage \& Mangrum, supra note 142, at 1094 ("Restgntutum need not represent the defeat of the impeachment process but instead mat be just one aspect of its successful operation."); BELkiAP TRIAL. supra note 18, at 85 (opmen of Senattor Frelinghuysen) (" $[\mathrm{I}] \mathrm{f}$ he resigns, removal, the main object of mpeachment, is effected.").

238. See infra Part VIII.B.

239. See infra Part VII.A. Some have argued that disqualtication is a pomeless exercise, because it is implausible that a convicted official would be elected or nominated and confirmed. E.g., BELkiAP TRIAL, supro note 18, at 116 (opmon of Senator Eaton) (arguing that disqualification is irrelesant, presuming thit the Senate confirmation process and electoral college will keep conticted officers out of future office). This may diminish the importance of disqualification, but even ats a practucal matter, there is a chance that such officials could stage a comebach. See Part V'Ill.A. infro, discusses some of these practical considerations. Most famousls, Judge Alcee ll.stungs was elected to the House of Representatives after being impeached, conncted, and removed from office. See supra note 12. 
possible punishments included disqualification among them. '"u Especially in an age of long, varied careers, it was very significant that an impeachment conviction said not only "get out!" but added an emphatic and irreversible "and stay out!" It is bad to be removed from office, but it surely is no small blot to be "sentenced to a perpetual ostracism from the esteem and confidence and honors and emoluments" of the United States without hope of pardon." This fact was recognized in 1787 and after even by critics of late impeachment, one of whom exaggerated only a bit when he said:

[A] man who stands convicted of high crimes and misdemeanors committed while in office, and is sentenced by the court of impeachment to perpetual clisqualification, is held by public opinion to be a living, moving infamy, a moral leper, shunned by his fellow man and without hope of pardon this side [of] the grave. ${ }^{212}$

A critic might still argue that disqualification functions structurally as leverage: If removal were the only possible penalty, parties would have little to lose in fighting impeachment tooth and nail. By upping the ante, the addition of disqualification provides an incentive for officials to resign, essentially dealing themselves a plea bargain down to simple removal and saving Congress tremendous resources. Indecd, many more officers facing impeachment have resigned (dorens) than have been convicted and disqualified (two). ${ }^{213}$ But this vic'w is not tenable. Either disqualification is a significant punishment, or it is not. If it is not, then it does not serve the plea-bargain purpose. If it is a significant punishment (onc certainly hopes that it is), it should not be presumed lightly that

240. See supra Part III.B.2.

241. THE. FEDERUISI No. 65, at 399 (Nexander Hamilon) (cinton Rosuter ed. 1961).

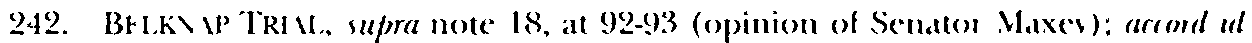
at 153 (opinion of Senator Dawes) ("L,se the leper he stands alone, shumed bv all clem

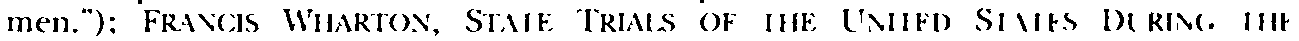
ADMIVISIRUIOSS OF WASHINGION TVD ADIIS 301-02 (Burt Franklin 1970) (18.19) (argument in impeachment case of William Blount): see also, e.g., State , H.ll. 55 N.WW 794,796 (Neb. 1893) (rejecting late impeachment in state case but stating that "[alll will concede that disqualification to hold office is a punishment much greater than removal"); CONG. GLOBE, 29th Cong., 1st Sess. 641 (1846) (statement of Rep. Adlums) ("I] $\mathrm{f}$ ans public officer ever put himself in a position to be tried bv umpeachuent. he would have verv little of my good opinion, if he did not think disqualification form holding office for life a more severe punishment than mete removal from oflice ").

243. See $m$ fra notes 411 and 522 . 
the Constitution allows it to be evaded so easily. Moreover, the more likely disqualification is to be significant-that is, the more likely the target is to want to return to government-the more important it is to actually apply it. Returning to the plea bargain analogy, consider that a possible death sentence may convince murderers to plead guilty in order to get a life sentence. But if such a sentence arrangement were solely up to the murderer, then no one would ever get the death penalty, a problem given that sometimes the prosecutor actually wants to seek the death penalty and that it is precisely in those cases that the murderer would be most likely to receive it.

It is more likely that disqualification is meant to serve as an actual punishment. ${ }^{2+4}$ As a result, impeachment (unlike expulsion) is not just about removal, and late impeachment is essential. Without it, a party by resigning, or a President by firing him, can flout any attempt by Congress to disqualify. ${ }^{2 t "}$ Although the party would be submitting to removal, the significant penalty of disqualification (and possibly others ${ }^{2+4}$ ) would be taken off of the table. To be sure, some parties would stand and fight their impeachment. If they felt that they had a chance to prevail, they might not resign even to the end. But parties who know that they will be convicted - the worst offenders, roughly speakingwould have no reason not to resign. The outer bounds of the impeachment power would thus be scaled back, not because the offender merited lenient treatment but paradoxically because he did not. The Senate would be rendered, as one senator put it in a late impeachment case "the only court in Christendom whose jurisdiction ... depends on the volition of the accused. ${ }^{247}$

\section{The Indistinguishable Stages of Impeachment}

Late impeachment presents a line-drawing issue. Virtually every opponent of late impeachment concedes that at a certain point in an impeachment proceeding, the target loses the ability to end Congress's jurisdiction by resigning. Take an extreme

244. Indeed, the First Congress established it as punishment for other offenses ats well. Though this is a constitutionally problematic infringement on the Prestent's appointment power, it shows that disqualification was taken seriousls in the 1780s. Sex infra note 549 .

245. See infra Part V.D.

246. See infra Part VII.B.

247. BELKNAP TRIAL, supra note 18, at 359 (opinion of Senator Nonwood). 
case: An officer is impeached, tried, and resigns between the casting of the 66 th and 67 th votes to convict. ${ }^{2+8}$ Few would arguc that such a conviction would not be valid. This is the view not just of late-impeachment opponents issuing dicta to avoid looking extreme; this is a distinction drawn by state courts that have reviewed analogous state cases. The question then becomes one of line drawing. Can the officer strip jurisdiction by resigning before the Senate vote starts? Before the trial starts? Before the House vote starts? Before the House debate begins? Before the House committee proceedings begin?

In some states, there is an arguable textual and structural basis for drawing a distinction between the stages of impeachment. For instance, when the Nebraska Supreme Court rejected late impeachment in State $v$. Hill," state law provided: "An impeachment of any state officer shall be tried, notwithstanding such officer may have resigned his office, or his term of office has expired."2:0 This language more easily supports the notion that impeachment is limited to sitting officers but that trial is not. ${ }^{2.11}$

In the federal Constitution, however, there is no such basis to distinguish between the stages of the impeachment procecdings. The only possible source of a limitation on the timing of impeachment comes from Article II, Section 4, which states that "The President, Vice President, and all civil Officers of the United States, shall be removed from office on Impeachment for, and Conviction of, Treason, Bribery, or other high ('rimes and Misdemeanors." If the mention of removal means that only those who can be removed can be "impeach[ed] . . and convict[ed]," then resignation would stop the proceedings even at the very last possible moment of the Senate vote before conviction. ${ }^{2.52}$ Similarly, if only currently sitting "civil officers" can be impeached and convicted, an effective resignation would stop proceedings.

248. An even more extreme case is possible: resigning after the vote but before the pronouncement of judgment. See, e.g., infra Part IV.B.2.c (discussing case of I e.s governor James Ferguson).

249. 55 N.W. 794, 798 (Neb. 1893). The Hall case is cliscussed an delall In P'al VI.B.2.b.

250. Hll, 55 N.W. at 798 (quoting NEB. CovP. SIAI. ch. 19.\$8(1891)),

251. Indeed, this is the conclusion that the Hall Court reached. Sep al. Another example is the New Hampshire language specifying that the Senate shall inv "all impeachments made by" the House. See supra text accompanying note 87.

252. See Belkiap TRIAL, supra note 18, at 111 (opinion of Senator Mitchell). 
If one is not troubled by the possibility of the defendant terminating the tribunal's jurisdiction, then this is not a problem. ${ }^{253}$ But while one might wish to give Congress the option of declaring victory and ending proceedings, it is quite another matter to say that Congress is constitutionally disabled from continuing impeachment proceedings in such a situation.

If late impeachment is permitted, then this line-drawing problem is mooted. But some critics of late impeachment, aware of this problem, have drawn a line at the beginning of "the proceedings." They declare that once jurisdiction is established in the House, there is nothing that the defendant can do to prevent impeachment proceedings but that any other late impeachment is forbidden. ${ }^{254}$ In doing so, they raise another line-drawing issue. One must then determine when the proceedings begin: When an accusation is made on the floor of the House? When the matter is referred to a committee? Others draw the line at impeachment itself. Once the House impeaches, they argue, the Senate has jurisdiction to finish the process. If the defendant resigns before the House completes its vote, however, the case ends. ${ }^{.955}$

These distinctions may make sense as a matter of abstract equity or as a matter of ideal structure, but they do not have any basis in the text or structure of the Constitution. If the Constitution limits impeachment in the House and trial in the Senate to sitting, removable "officers," then it necessarily follows that a target of impeachment can end the proceedings any time he chooses. The fact that this conclusion is unacceptable to most opponents of late impeachment shows that opposition to late impeachment, while stemming from bare textualism, cannot remain there without either intolerable results or inherent selfcontradiction.

253. See, e.g., id. at 43 (defense counsel in late impeachment cabe concedung that resignation would be effective at any stage). But see id. at 68 (defense coumsel dismmsmg question as unnecessary to decision of case). Obviousls, this Article mantanus that there are significant structural problems with taking such power awat from (ingress. Sex infru Parts V.B (discussing structural importance of disqualification, whoh could cassls be mooted if late impeachment is impossible) and V'.D (discussing structural restncuons on the President in cases of impeachment).

254. See, e.g., BELkNAP TRIAL, supra note 18. at 8.3 (opinon of Senator Frelunghusen in Belknap case that resignation cannot end trial once begun): ud. at 101 (opmun of Senator Christiancy) (hinting at same); infra note -493 and accompanumg text.

255. E.g., BELKNAP TRIAL, supra note 18, at 126 (opinion of Senator langalls). 


\section{Pardons, Presidential Removal, and the Impeachment as Inquest}

The Constitution specifically forbids the President from using his pardon power in cases of impeachment. ${ }^{251}$ A President's ability to flout impeachment by removing the official in question-perhaps simply by reassigning him to a post on his staff that does not require Senate confirmation ${ }^{257}$-is structurally incompatible with the impeachment exception to the presidential pardon power. It seems illogical that the President could use his removal power to achieve the same end indirectly. Alternatively, it seems strange that a more respectful President could be forced to choose between leaving the offender in office or removing him promptly but preventing him from being fully punished.

The impeachment exception to the pardon power arose from the case of the Earl of Danby in the late seventeenth century. ${ }^{27 *}$ King Charles II pardoned Danby not because Danby was innocent but because the King was guilty of questionable dealings with France. Had the impeachment trial gone forward, the evidence uncovered would have embarrassed the King; by pardoning Danby, Charles prevented the investigation." Parliament later precluded pardons from barring an impeachment in an effort to prevent a recurrence of this assault on its authority. ${ }^{200}$

In the United States there is no reason that Congress camnot pursue the President directly, and Congress can launch investigations short of impeachments. So there is less danger that a President might pardon a subordinate to prevent a congressional investigation. Moreover, because a President is no king and serves for a maximum of ten years, ${ }^{201}$ the general possibility exists that a future administration will be able to

256. U.S. Co.SST. art. II, $\$ 2, \mathrm{cl} .1$.

257. See supra text accompanying note 4 (presenting such a hypothetical).

258. Kalt, supra note 13, at 783-84 (describing case of the Earl of Danby and subsequent parliamentary trimming of the roval pardon power).

259. See zd. Charles had no particular interest in protecting Damby himself; the Eal languished in the Tower of London for years, despite his pardon. Id. at $784 \mathrm{n.39}$.

260. Id. at $784 \&$ n.40 (discussing 1701 Act of Settlement).

261. L.S. CoNST. amend. XXII. Cf. supra note 130. Before the passage of the Twenty-Second Amendment-including the framing era-the fact that a President possibly could serve forever provided a reason to emphasice removabulity when discussing impeachment. These views are consistent, or at least not inconsistent, with late impeachability. See supra text accompanying notes 125-31, 149-50. 
criminally investigate the President and his minions. But regardless of the potential for criminal proceedings in a new administration, Congress is the grand inquisitor of the linited States, with the explicit power to investigate the conduct of executive and judicial branch officials outside the confines of the criminal law. Even though Congress can hold hearings and launch investigations without resorting to impeachment, impeachment is the only process that the Constitution provides for investigating public officials' conduct and for rendering a formal verdict on abuses of the public trust.

In other words, impeachment is supposed to check presidential excesses, and the Constitution explicitly prevents the President from assaulting congressional impeachment jurisdiction via the pardon power. It does not logically follow, then, that the President could remove a subordinate and thereby terminate the highest of congressional inquests. As a member of the House about to vote on a late impeachment incredulously put it to an opponent:

Will you say to the country that he whom you have placed in power at the other end of this avenue is able to rob an American Congress of a right and a power that a King of Great Britain could not take from Parliament? [Applause on the floor and in the galleries.] Is that your theory?

This would be a curious theory indeed.

Moreover, it would be strange if the impeachment power was limited in a way that gave a President deferring to Congress an incentive to allow a malfeasant officer to remain in office. The President also has the power to remove executive officials, but without late impeachability, a President would be hamstrung if disqualification of the official were appropriate as well. Impeachment would be necessary to level such a punishment, and if late impeachment were impossible, the President would have to choose between a full penalty and immediate removal. Disqualification would be most appropriate in the worst casesthe very cases in which immediate removal by the President

262. 4 CONG. REC. 1432 (1876) (statement of Rep. Blackburn). The (onstitution actually protects impeachment from pardons even more strongle than the English sistem did. The English pardon exception presented the king from prempting an impeachment trial but did not prevent him from pardoning the target after comsction The American pardon exception prevents the President from preempting or undonng an impeachment. See supra note 13. 
would be most important for the country-and so barring late impeachment presents yet another structural hiccup. ${ }^{2,3}$

As a final note, there is no question that a broader impeachment power carries with it a greater possibility of abuse, especially given that the President has no ability to stop an impeachment, and the courts have little more. This is not, however, a reason to give the President questionable powers against impeachment. Congress can abuse impeachment whether or not late impeachment is part of its arsenal, but the Constitution provides structural safeguards against such abuses. ${ }^{2 n t}$ Presidential power is not one of them.

\section{E. The Four Interpretations}

Recall the four possible interpretations of the scope of impeachment timing: ${ }^{26,3}$

Must the party presently be in office?

Must the offense have occurred while the offender was in office?

\begin{tabular}{|l|c|c|}
\cline { 2 - 3 } \multicolumn{4}{c}{} & \multicolumn{2}{c|}{ Yes } & office? \\
\hline Yes & 1 (conservative) & 2 (late) \\
\hline No & 3 (Whitewater) & 4 (radical) \\
\hline
\end{tabular}

Analyzing each possibility from a structural standpoint, severe defects emerge in Interpretations \#1, \#3, and \#4. Interpretation \#2 is not perfect, but it is the least problematic.

The "radical" approach to impeachment (\#4) would allow anyone who had once been a civil officer to face impeachment, regardless of when he committed his offense. A view this broad would not dissuade sitting officers from misconduct in office, nor would it serve the purpose of removing "bad" officers. It would function only to disqualify "bad" people from future federal office, but there seems to be no basis under the

263. It is perhaps not a coincidence that the only federal late impeachment It, occurred during a time when the presidential removal power was restricted. The Belknap case fell in the shadow of the Tenure of Office Act, whuch made it difficult for the President to remove, or even suspend, members of his Cabinet. Sep BfI hivi I RIVI. supra note 18, at 62 (House manager noting limitations on presidential removal powes and ashing. "Yust a defaulting Treasurer of the L'nited States be left m chage of the entire Treasury until conviction and sentence?"). It does not appear, however, that mout proponents of late impeachment considered this argument signific ant. In ant case, llee Act was later correctly declared unconstitutional. Wvers v. Lnited States, 272 I $^{*}$ S. 52.176 (1926).

264. See mfia Part VílI.G.

26.5. See supra Part IV.B.2. 
Constitution to distinguish between former officeholders and mere private citizens in this regard. If a private citizen should be disqualified from ever holding federal office again because of something he did as a private citizen, why should it matter whether or not he held a federal office at some other point in his life? Once again, the radical approach would transform the designation that "civil officers" are susceptible to impeachment from a check against federal officeholders into an illogical and arbitrary formalism. ${ }^{966}$ There is no structural support for such an interpretation.

The "conservative" approach (\#1) would allow only" impeachments against sitting civil officers, for offenses committed in that office. A Supreme Court justice would not be impeachable for offenses committed as a circuit court judge. ${ }^{* i}$ A Secretary of State would not be impeachable for offenses committed in his earlier job as Secretary of the Treasury. More problematically, a second-term President might not be impeachable for offenses committed in his first term. Perhaps the terms could be treated as continuous, so that a second-term President would be impeachable for actions in his first term if the terms were consecutive; this is a common interpretation of impeachment in states. ${ }^{265}$ Under this interpretation, however, Grover Cleveland would not have been impeachable in 1893 for something he had done as President in 1888, even though Bill Clinton would have been impeachable in 1998 for something he had done as President in 1993. Again, this distinction seems to lack a structural basis.

Proponents of this approach would likely respond that an intervening election or Senate confirmation would justify a bar on impeachment. If someone can convince the President and(/or?) Senate or the electorate that he is worthy of office despite his past offenses, Congress should not be allowed to reverse that determination. ${ }^{20}$ But why should election vindicate

266. See id.

267. This issue was implicated, but not decided definusels, in the andogous Archbald case. See infra Part V.A.j.

268. This issue has arisen in state cases enough that it is discussed in the (ionpus Jurns Secundum. It has been held that continuous terms in the sime office are consedered one unit for impeachment purposes, but discontinuous terms or different oflices are not. Ser 67 C.J.S. Officers $\$ 120$ (c) (1978).

269. See Two Proceedings of the Senate and the House of Representatrues of the l'mted states in the Trial of Impeachment of Robert II. Archbald. S. DOX.. No. 62-1140, at 1634-35 (1913) [hereinafter Archbald Trial] (opinion of Senator Bnan) (arguing against a simlat sort of 
Clinton and not Cleveland? Moreover, even if an impeaching Congress should take this factual matter into account, there is no guarantee that anyone would know of the past illicit conduct at the time of reelection or reconfirmation. One need look no further than Watergate for an example of presidential misconduct that was only uncovered after an intervening election. Indeed, by its very nature, electoral chicanery like the Watergate break-in is the last sort of high crime that should be placed beyond the reach of impeachment. ${ }^{271}$ In any case, the fact that confirmation or election would solve this problem in some of these cases is no reason to bar impeachment in all of these cases.

The "Whitewater" interpretation (\#3), which allows impeachment for any past actions so long as the party is currently a civil officer, would solve the structural problems of the "conservative" approach. It is worth noting, of course, that if an officer is being impeached under Interpretation \#3 for an offense committed in a previous office, this is a form of late impeachment. In other words, the Whitewater view allows late impeachment, but only if the defendant is serving in a ncw office.

Interpretation \#3 has an admittedly strong structural underpinning: If impeachment is about removal, then this approach fulfills that objective in the broadest possible way. A civil officer is removed from his current office if he is decmed unfit for that office, regardless of when his unfitness manifested itself. As Jorge Souss put it:

[A] re we supposed to believe that if we now discovered that Christine Todd Whitman or Stephen Brever (to pick two "officers of the United States" at random) were serial killers back in the early 1980s that Congress could not impeach them? Or that if George W. Bush robbed a jewelry store on the morning of January 20, a few hours before being sworn in, that he would not be subject to impeachment for such behavior? Such results would be unimaginable, and for good reason. ${ }^{271}$

This interpretation also has an answer for a converse problem: Suppose a President robbed a jewelry store not an hour before

late impeachability and stating "[b]oth the President when he nominates and the Sencte when it advises and consents, ought to be satisfied, it seems to me. with the chatet and qualifications of the citizen").

270. See supra text accompanying notes 125-31 (conventun debates disc ussmg thus issuc).

271. Sef Souss, supra note 16. 
he took the oath but an hour before his successor did? Should he be able to elude impeachment? And what about the official whom the President cannot pardon but can fire? The Whitewater interpretation would provide that impeachment could not occur in such situations unless and until the culprit returned to office, ${ }^{273}$ but it would deny that this is a problem, given the possibility of regular criminal prosecution.

This is fine for Souss's jewelry store owner, but it is of cold comfort once one returns to the real subject of impeachment, public offenses. What about a President who waits until the last day of his administration to abuse his authority as Commander in Chief? Or to issue corrupt pardons? Or to commit any other abuse of the public trust that cannot, should not-or, as a practical matter, will not-be covered by the criminal justice system $?^{274}$ Surely, it is no coincidence that neither William Blount nor William Belknap, the only two men subjected to late impeachment, were ever criminally prosecuted for their offenses. ${ }^{275}$ And what of the fact that criminal liability is available for all impeachments, not just late ones? Under the "Whitewater" reasoning, the possibility of criminal prosecution would preclude any "regular" impeachment as well.

Impeachment addresses great offenses against the publicoffenses that the criminal law may not touch or that ordinary criminal justice is not equipped to handle properly. As Alexander Hamilton wrote in The Federalist, impeachment cases are placed under the purview of Congress in large part because the very nature of the offenses at issue makes them inextricably politicized. Thus, the House-not regular prosecutors and

272. See supra Part V.D.

273. The Whitewater interpreter could make good use of the fact that unpeachment would reemerge as an option if the target were to return to office. In a was, this would accomplish not just removal but disqualification. Therefore, the angument would follow, there really would be no reason to pursue a late impeachment, becaluse both constitutionally permissible ends of an impeachment conviction would be off the table.

But disqualification would not completely disappear from the table. The fact that the offender would face potential impeachment if he returned to office would not mean that he could not return to office. It would mean only that if he did and if he was not confident that Congress had shifted its predilections in his favor. he would be in the same position as before he resigned.

274. See Turley, supra note 165 , at 56 ("At a time of lost public confidence in the integrity of the government, the conduct of a former official can demand a politucal response. This response in the form of an impeachment mas be more important than a legal response in the form of a prosecution.").

275. BUSHNELL, supra note 16, at 37 (Blount): ad. at 189 (Belknap); ser also infra Part VIII.A. 
courts-is the proper body to lead it. ${ }^{270}$ The Whitewater view misses the point in its argument that impeachment is for current officers and that anyone else is left to the criminal law alone. Impeachment draws its institutional reason for being from the nature of the offense, not the nature of the defendant's employment at the time of trial. If it did not, there would be no reason to limit it to high crimes and misdemeanors.

The "late" interpretation (\#2) comprehends this point and each of the others above as well. It recognizes Congress' power to use impeachment to inquire "into the conduct of public men," however late in their terms their offenses occur, and however long their offenses have been secreted. In cloing so, it allows impeachment to present a full incentive for properly performing the duties of federal office. It vindicates the significant structural role of disqualification. ${ }^{277}$ It permits Congress to fulfill its constitutional duty to deter, investigate, rule upon, and fully punish high crimes and misdemeanors, regardless of how willing the defendant and/or President are to subvert Congress's jurisdiction with evasion and chicanery. Finally, and most specifically, it precludes the President from evading the constitutional bar on his power to pardon in casses of impeachment, and it eliminates any incentive to kecep criminals in office to ensure that they remain eligible for punishment.

\section{PRECEDENT}

Unlike the speculative and inferential arguments detailed in the previous Parts of this Article, the arguments from precedent in this Part are concrete and directly address the issuc of late impeachment. In two cases-those of William Blount and William Belknap-the Senate debated late impeachment at length. Unfortunately for our purposes, it did not reach a decisive result in either case. In Belknap's case, the Senate did formally accept late impeachment, but while enough senators

276. Sep THE FEDER ULIST No. 65, at 397 (Alexander I lamilton) (Clinton Roswler ed.. 1961) ("What, it may be asked, is the true spirit of the instituton itsell? Is it not desugned as a method of NAIIONAL INQL EST into the conduct of public men? It this be the design of it, who can so properly be the inquisitors for the nation as the representative of the nation themselves:").

277. If an ex-officer is serving in a new office at the tume of the mpeachment and conviction, disqualification would amount to removal as well. In anv case, temor.ll would seem to be required by Article II, $\$$ t esen if disqualification is not. 
agreed to allow the trial to go forward on the merits, enough senators disagreed to acquit Belknap. Still, the Belknap case proposes that the House can impeach and the Senate can try officials even after they have left office. Even as the case shows how controversial late impeachment is, if it stands for anything, it stands for late impeachability.

In other cases, Congress has declined to press late impeachments, allowing officials to resign and the cases to drop. But the fact that Congress had no need or reason to pursue these officials did not mean that Congress lacked the authority to do so. Indeed, in some of these cases senators explicitly recognized this authority. In all, the actual precedents relating to late impeachment are consistent with the conclusion that late impeachment is available to Congress, even if it is not always a worthwhile remedy to pursue.

Impeachment precedents are not formally binding on Congress, as its members are responsible only to the voters and not to any higher court. In each case, each representative and senator needs to determine whether a proceeding is constitutionally permissible. ${ }^{278}$ This Part of the Article does not suggest that Congress would be unable to decide that late impeachment could be inappropriate or even impermissible. Rather, it is intended to show that when given the opportunity, Congress has recognized the possibility of late impeachment.

Filling out the historical record, state proceedings provide still more evidence that late impeachment is possible, some of which rests on state constitutional language quite similar to that in the federal Constitution. Even more so than in the federal context, though, these precedents send mixed messages.

\section{A. Federal Cases}

There is precedent for late impeachment in the federal system. While there are cases in which impeachment was abandoned upon the resignation of the target, in no case was late impeachment specifically deemed unallowable. In fact, official House precedent, citing the Blount and Belknap cases, indicates that the "[a]ccused may be tried after resignation. ${ }^{\text {"? }}$

278. See infra note 372 and accompanying text.

279. 3 ASHER C. HINDS, HINDS' PRECEDENTS OF THE HOL SE OF REPRESENYAITIES OF THE UNITED STATES 307 (1907) (describing "nature of impeachment"); sxe infra Parts VI.A.1 (Blount case) \& VI.A.5 (Belknap case). 


\section{Blount}

The first federal impeachment case, that of Senator William Blount, was a late impeachment and was dismissed by the Senate for lack of jurisdiction. This lack of jurisdiction did not, however, arise from the fact that Blount had already left office. Blount was a delegate to the federal Constitutional Convention from North Carolina, served as governor of the Southwest territory for six years, and was one of Tennessee's first United States senators. ${ }^{2 * 0}$

Blount apparently became involved in a British plot to take Florida and Louisiana from Spain, a United States ally. After hearing the charges against Blount, forwarded by President Adams, the House of Representatives impeached him on July 7. 1797. ${ }^{2 \times 1}$ The next day, the Senate expelled Blount for his "high misdemeanor" by a vote of twenty-five to one and adjourned until November. ${ }^{222}$ During this recess, Blount was ordered to appear before a Senate select committee. He refused to return from Tennessee, however, and the Senate impeachment trial began without him in December 1798. ${ }^{283}$ The trial took only a few days and never got to the merits. ${ }^{2 * 4}$

Before arguing anything else, Blount's representatives, Jared Ingersoll and A.J. Dallas, asked the Senate to dismiss the impeachment case:

[A]lthough true it is, that he, the said William Blount, was a Senator of the United States from the State of Tennessece, at

Some have argued that one successful impeachment, against Juclge We'st IIumphress in 1862, was a late impeachment. Sep 43 (CONC. REC. 324 (1875) (statement of Rep) Butler). Humphreys had abandoned his judicial post to accept one in the contederds: Id. Thus, he can be said to have left office before his impeachment. Sor ul. But Humphreys had never resigned, and it was only with the successtul (and uncomtested) impeachment that he was officially removed trom office. See ul. at 325 (statement of Rep Tremain). See generally BL SHNEI.L, supra note 16, at $115-24$ (describing Ilumplucess ase)

280. BlsiNel., supra note 16, at 27 (outlining Blount's career); sep also l.awence

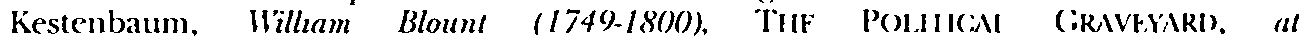
http://www:politicalgraveyard.com/bio,'blount.html (last moditied May I3, 2001).

281. BI SINELI, supra note 16, at 27-28.

282. 5 ANNAIS OF COV(;. 43-46 (1797).

283. Bt SHNEL., supra note 16. at 31 .

284. Vice President Jefferson, who presided over the trial, must have been surpused at how swifty it proceeded once it finally began. Earlier he had wntten of the case. "Articles of impeachment were vesterday given in against Blount. . . Is a Sellatou impeachable? Is an ex-Senator impeachable? You will readily conceive that these questions, to be settled by twenty-nine lawvers, are not likely to come to speerly ussue" WHARION, supra note 242, at 315 n. (quoting Jefferson's correspondence). 
the several periods in the said articles of impeachment referred to, yet that he, the said William, is not now a Senator, and is not, nor was at the several periods so as aforesaid referred to, a civil officer of the United Sates, nor is he, the said William, in and by the said articles, charged with having committed any crime or misdemeanour in the execution of any civil office held under the United States, nor with any malconduct [sic] in a civil office, or abuse of any public trust in the execution thereof. ${ }^{285}$

Blount's argument was that senators are not subject to impeachment, and even if they are, he was no longer a senator. Even if that did not matter, he claimed, he was not charged with committing his offenses as a public officer-that is, a private citizen could have been charged with the same actions.

In his argument to the Senate, James Bayard, the leader of the House managers, attempted to refute all of Blount's alternative arguments at once. He countered that Article II, Section 4 did not purport to limit the Senate's jurisdiction; therefore, it did not limit impeachment to civil officers. ${ }^{2 \infty}$ To Bayard, American impeachment was coextensive with English impeachment unless a specific exception was mentioned in the Constitution. "This would mean that, as Blackstone had recounted a few decades earlier with regard to England, private citizens would be impeachable for offenses against the public; the allegations against Blount at least qualified as that. ${ }^{3 \times s}$

Turning to the late impeachment issue, Bayard argued that it was irrelevant that Blount was no longer a senator because he had been one "at the time the articles were preferred [sic]. Technically, this was not true, because, as in most early impeachments, the actual impeachment was voted upon before specific articles were adopted. ${ }^{900}$ In Blount's case, the House did not approve the articles until January, 1798, several months after

285. Id. at 260 .

286. Id. at 263. See supra Part IV.B.1 (discussing and rejecting this new of Arucle II. $\S 4)$.

287. WHARTON, supra note 242 , at 26465 . See also supra note 142 and atcompamsmg text.

288. See supra note 39 and accompanying text.

289. WHARTON, supra note 242, at 271.

290. See BUSHNELL, supra note 16, at 30 (describing order in Bloumt case): GERHARDT, supra note 12, at 26 (describing modern change to voung on artucles concurrently with vote on impeachment). 
Blount's expulsion from the Senate. ${ }^{201}$ Blount, however, had been a senator when he was impeached, and Bayard made a strong point that "no subsequent event, grounded on the wilful act, or caused by the delinquency of the party, can vitiate or obstruct the proceeding." "212

Bayard sidestepped the harder question of whether an official can be impeached after leaving office and limited himself to the stronger argument that an official impeached while in office can be tried after leaving office. Bayard did not concede anything; he simply limited his discussion to the easiest case. While Bayard's distinction may have made sense from a strategic standpoint, no historical, structural, or textual basis exists to distinguish between late impeachments and late trials. ${ }^{293}$

Blount's representatives made a similar effort to narrow their argument to their strongest possible point, addressing late impeachment in the process. Dallas conceded that "there was room for argument, whether an officer could be impeached after he was out of office; not by a voluntary resignation to evade prosecution, but by an adversary expulsion ...." Dallas's point was that late impeachment might be appropriate if the party had resigned, but it could not be appropriate if the party had been expelled-especially if he were expelled from the same Senate that would try him. Ingersoll put it more strongly later in the trial:

I certainly never shall contend, that an officer may first commit an offence, and afterwards avoid punishment by resigning his office; but the defendant has been expelled. (ain he be removed at one trial, and disqualified at another, for the same offence?... Is there not reason to apprehend the strong bias of a former decision would be apt to prevent the influence of any new lights brought forward upon a second trial ${ }^{* 35}$

Thus, while Dallas and especially Ingersoll apparently conceded that late impeachment was possible, they found that latte impeachment of an expelled senator made little structural

291. WHARTON, supra note 242 , at 252.

292. WHARTON, supra note 242, at 271.

293. See supra Part V.C.

294. WHARTON, supra note 242 , at 284 . See also supra note 197 (discussing stuuctural interplay of impeachment and expulsion, supporting notion that no members of Congress can be impeached).

295. WHARTON, supra note 242 , at 296. 
sense. Notably, they did not raise any practical arguments against late impeachment-they did not argue that there is no good reason to impeach someone already out of office.

In any event, the Senate agreed to reject the case and not hear the merits. A resolution specifying that "William Blount was a civil officer of the United States . . . and, therefore, liable to be impeached by the House of Representatives," was rejected fourteen to eleven. ${ }^{296}$ In other words, a majority of the Senate did not believe that Blount had been a civil officer. The Senate also accepted a second resolution, which said only that Blount's plea was sufficient and that the Senate had no jurisdiction, by the same vote, and the case was dismissed. "The three senators who had been delegates to the constitutional convention (John Langdon, Alexander Martin, and George Read) voted with the majority on both votes. ${ }^{298}$

Some critics of late impeachment have pointed to the indefinite nature of the resolution dismissing the case, noting that it approved only Blount's alternative pleading, which included not just the senator/officer issue but also the late impeachment issue. ${ }^{299}$ Nevertheless, the previous resolution, rejected by the same fourteen to eleven vote, focused only on the senator/officer issue, so if the Blount result can be said to have definitively settled anything, it is that senators are not civil officers. Indeed, the Blount case is generally regarded as standing only for that principle and for the corollary that only civil officers are subject to impeachment. ${ }^{300}$

\section{Calhoun and Webster}

Two non-impeachment cases expose the rise and fall of another side of the impeachment power. Impeachment serves not just as a means of trying public offenses, but as a means of investigating them and vindicating the innocent. This broader

296. Id. at 315-16.

297. Id. at 316 .

298. Id.

299. E.g., BUSHNELL, supra note 16, at 38; HOFFER \& Hi'น., supra note 1, at 25ĩ; tnfra note 360 and accompanying text.

300. See, e.g., State v. Hill, 55 N.W. 794, 797 (Neb. 1893) (rejectung late impeachment but conceding that Blount case provides no precedemt on the question): GERHARDT, supra note 12, at 49 (concluding that the precedent of the Blount case is unclear); RAWLE, supra note 35, at 170 (discussing binding nature of Blount precedent, with which author disagreed); 2 STORY, supra note 42, at 258 (rejecting idea that Blount decision "turned upon" late impeachment question). 
notion of impeachment as the constitutionally preferred means of investigating federal officials' actions has much to commend it, though in practice it has not gained acceptance. In 2001, impeachment is seen as something to be avoided if one is innocent.

The case of John C. Calhoun shows the potential use of impeachment as a defensive technique to bring accusations into the open and resolve them with Congress's decisive investigative power, rather than letting them fester and thrive on innuendo. If a congressional committee examines a case and finds it not worthy of impeachment, the would-be target can proclaim vindication. Then-Vice President Calhoun was seeking such vindication when, in 1827, opponents began circulating rumors of his financial misconduct when he had served as Secretary of War. ${ }^{811}$

Despite the fact that he no longer held the office at issuc, Calhoun appealed to the House as the "grand inquest of the nation" "

In claiming the investigation of the House, I am sensible, that, under our free and happy institutions, the conduct of public servants is a fair subject of the closest scrutiny and the freest remarks . . . but when such attacks assume the character of impeachable offenses, .... an officer thus assailed, however base the instrument used, if conscious of innocence, can look for refuge only to the Hall of the immediate Representatives of the People. ${ }^{30: 5}$

The investigation took place and Calhoun was officially cleared. ${ }^{3 / 4}$ By raising the stakes beyond that of a mere congressional investigation, Calhoun had forced his accusers to put up or shut up and laid to rest the accusations against him.

301. See 3 CONG. DEB. 575 (1827). Because Calhoun was Vice President at the ume of the rumors, some who reject late impeachment might have found him susceptible (o) impeachment anyway. See supra Part V.E (discussing "Whitewater" interpretation. whu h allows for impeachment of sitting officers for offense's committed in previous oflices).

302. 3 (CNG. DEB. 574 (1827); of. supra text accompanying notes 42-43, 85. 87; Pa1t V.D (using term "grand inquest" to describe lower-house impeachment role).

303. 3 CONG. DEB. $574-75$ (1827).

304. Id. at 1123-24, 1143. Since there was no impeachment. Congress avoided the issue of whether the Vice President presides over the Senate when it is trying him. Soe also supra note 139 and accompanying text (discussing this constitutional dilemma). 
Nineteen years later, a similar situation faced Senator Daniel Webster. ${ }^{305}$ The great Whig leader had served as Secretary of State under President Tyler. Now, three years after he had left that post (and four years before he returned to it), Webster found himself accused of improperly using secret funds. The accusations were scurrilous and unfounded, but they were made on the floor of the House of Representatives and received significant attention over the following months. "Some House members, including at least one Webster proponent, surmised that pursuing impeachment was a possible avenue to resolve the issue-an interpretation that his attackers were all too happy to support. $^{308}$

Not all of Webster's defenders welcomed impeachment. One argued strenuously that late impeachment was not possible. ${ }^{\text {s's }}$ It was in this context that Representative and ex-President John Quincy Adams made his famous comments defending Webster but upholding late impeachability. ${ }^{\text {s10 }}$ On the latter, he said:

I take occasion to say that I differ with the . . gentlemen who have stated that the day of impeachment has passed . . . . I hold no such doctrine. I hold myself, so long as I have the breath of life in my body, amenable to impeachment by this House for everything I did during the time I held any public office. $^{311}$

Adams's statement was not universally accepted. One colleague mused aloud that removal was the only purpose of

305. For a fair description of the Webster case, see BkilkiAp TR1.Al., supra note 1S, at 151 (opinion of Senator Dawes).

306. CoNG. Globe, 29th Cong., lst Sess. 636 (1846) (statement of Rep. (:.). Ingersoll).

307. The committee appointed to investigate the matter released its report in June. in which it declared that "there is no proof in relation to any of the charges to mpeach Mr. Webster's integrity, or the purity of his motives in the discharge of the dutues of his office." Id. at 946.

308. See, e.g., id. at 636 (statement of Rep. C.J. Ingersolt) (attackung Webster and wondering aloud whether Webster's alleged offenses mill be deemed mpeachable misdemeanors in office ${ }^{-}$).

309. E.g., id. at 638 (statement of Rep. Bayly) ("I would like to know how sou can impeach an officer. when he is no longer an officer:"); th. at 6.40 (statculent of Rep). Winthrop) (agreeing with Bayly). Bayly was a Democrat and thus not a partusin of Webster's; he apparently disagreed only with the more scurrilous aspects of Ingersoll's charges. See id. at 638 . Winthrop was a Whig.

310. Id. at 641 (statement of Rep. Adams) (defending liebster on ments but disagreeing with Rep. Bayly on late impeachment).

311. Id. 
impeachment, and so late impeachment made no sense. ${ }^{312}$ Adams responded eloquently that disqualification is a worse punishment than removal and that without late impeachment, the offender could skirt it:

[E]very officer impeachable by the laws of the country, is as liable, twenty years after his office has expired, as he is whilst he continues in office; and if such is not the case, if an officer could thus ward off the pains of impeachment, what would be the value of the provision . . . ?

Webster was never impeached. He did not seem particularly anxious to try the impeachment process as a method of clearing his name, and he was able to end the controversy by releasing documents that clarified his role. ${ }^{31 "}$ Still, this episode shows that late impeachment was on representatives' minds, even when it was far from likely to occur. These two cases thus provide a glimpse into congressional understanding of late impeachability during this time, and show that it had substantial support.

\section{Whittemore and Deweese}

Article I, Section 5, Clause 2 provides: "Each House may . . . punish its Members for disorderly Behaviour, and, with the Concurrence of two thirds, expel a Member." "This presents a keen analogy to the issue of late impeachment-it begs the question of whether an ex-"member" can be punished, just as Article II, Section 4 begs the question of whether an ex-civil officer can be impeached.

In 1870, the House of Representatives used its Articlc I, Section 5 power to censure Representatives Benjamin Franklin Whittemore and John Deweese for selling commissions to the Naval Academy. ${ }^{316}$ The House had prepared to expel them, but

312. Id. (statement of Rep. Bayly) ("Is not the judgment, in case of impeachment. removal from office?").

313. Id. (statement of Rep. Adams). Adams appeared to be talking more about himself than Webster. Adams also mentioned Presidents as being impeachable after leaving office, and his own tenure had expired almost twenty years before this. Those discounting Adams's statement in later years have thus portrayed his posituon as a contrarian conceit. See infra note 367.

314. See supra note 307.

315. U.S. Covsr. art. I, $\$ 5$, cl. 2.

316. CoNG. Globe, 41st Cong., 2d Sess. 1544-47 (1870) (recording resolutun condemning Whittemore's conduct as unworthy of a representative of the people); ad at 1616-17 (recording resolution condemning Deweese's conduct as uwworthy of a 
their resignations mooted this effort. ${ }^{31 ;}$ Still, the House unanimously concluded that it could censure these "members" even after they had left Congress. ${ }^{318}$

The Deweese case, the second of the two, spurred another question-whether the House could investigate members from previous Congresses; while Whittemore and Deweese had left the present Congress, they had been members of it. ${ }^{319}$ There was serious debate on this question, with no conclusive answer. ${ }^{500}$ In wrestling with this issue, Representative Bingham, the author of the Fourteenth Amendment, stated that it was "perfectly clear" to him that the House could not pursue ex-members of previous Congresses. ${ }^{321}$ Bingham added, however, that "there might be some room for inquiry" over the power to impeach an ex-member but for the fact that the Blount case had established that legislators were not civil officers subject to impeachment." Bingham believed that Congress could not attempt to punish its ex-members but was less limited in its ability to pursue late impeachment of civil officers.

\section{Delahay}

Judge Mark Delahay was impeached in 1873, when the House adopted a resolution of impeachment proposed by the Judiciary Committee. ${ }^{323}$ Delahay was alleged to have funneled $\$ 32,000$ from a confiscation case to a relative, but the impeachment rested solely on "the most grievous charge, and that which was beyond all question[:] that his personal habits unfitted him for the judicial office, that he was intoxicated on the bench as well as off." ${ }^{324}$

representative of the people); see also 2 HINDS, supra note 279. at 796 (describing condemnation of Deweese as censure); id. at 830 (same as to Whittemore).

317. See id at 1544 (Whittemore case); id. at 1617 (Deweese casc).

318. See id at 1547 (vote on Whittemore); id. at 1617 (vole on Deweese).

319. See id. at 1617 (statement of Representative Logan) (raising questuon of investigating committee's jurisdiction).

320. See id. at 1617-22 (recording debate on jurisdiction of investigating committee. including indecisive voting on motions).

321. Id. at 1618 .

322. Id.

323. Cong. Globe, 42d Cong., 3d Sess. 1900 (1873).

324. Id. 
Regardless of whether being a drunk is a high crime or misdemeanor, as alleged by the resolution, ${ }^{32}$ the important fact is that Delahay resigned before the House could draft specific articles of impeachment and bring the case to the Senate. "The House let the matter drop without any discussion on the record. If anyone took this to mean that the House did not think that it could pursue a late impeachment, however, he was proven wrong three years later.

\section{Belknap}

The 1876 case of Secretary of War William Belknap is the single most important precedent in the realm of late impeachment. The House impeached Belknap a few hours after he resigned, and the Senate tried him. The House unanimously voted, and the Senate ruled specifically, that resignation could not terminate the congressional impeachment process. Unfortunately for those seeking clarity, the Senate jurisdictional vote passed by a simple majority. The minority members who lost felt strongly enough about their position that most voted to acquit Belknap on this issue alone. Enough did so to prevent the Senate from obtaining the two-thirds vote necessary for conviction. Still, there was enough support for late impeachment that the five-month-long trial went forward on the merits. Moreover, the final vote was very close, suggesting that a more egregious case might have yielded a conviction.

Belknap was connected to a kickback scheme involving western trading posts. The Secretary of War granted post traderships, and they were lucrative positions. In 1870, Belknap appointed Caleb Marsh to the tradership at Fort Sill, Oklahoma but asked him to make an arrangement with the old post trader, John Evans, to protect the latter's property rights in the existing buildings and stocks at the fort. ${ }^{427}$ Marsh arranged to allow Evans to continue operating the post in exchange for $\$ 12,000$ a year in cash-half of which Marsh paid to Belknap's wife. ${ }^{32}$ The

325. Id. at 1899. Although labeled as high crimes and misdemeanors, many of the offenses for which federal judges have been impeached and convicted better fit the broader term of "misbehavior" specified in Arucle III, \$1. See supra note 198.

326. See VAN TASSEL \& FINKELMAN, supra note 1, at 119.

327. BeSHNEl.L, supra note 16, at 166 (summanizing tacts in Belknap case).

328. Ill. 
Belknaps eventually received over $\$ 20,000$ from the agreement. $^{329}$

The House Committee on Expenditures discovered the entire arrangement six years later. ${ }^{5 \$ 0}$ Belknap learned that he was about to be impeached and realized that there was one thing he might do to prevent it. After a discussion with House leader Hiester Clymer, Belknap apparently concluded that if he resigned he might avoid the unpleasant experience of a national inquest, additional publicity about his embarrassing conduct, and disqualification from office. ${ }^{\text {ssi }}$ Belknap hurried to President Grant's office and tendered his resignation at 10:20 A.M. on March 2, telling the overly credulous Grant that he was resigning to protect Mrs. Belknap. ${ }^{\mathrm{s}}$

Later that day, the House faced the question of how to punish Belknap. House members knew that Belknap had resigned and briefly debated their jurisdiction over former officers. A member of the committee argued that the Senate could still disqualify Belknap and pointed to the Hastings precedent." Representative Blackburn offered a fiery defense of late impeachment. ${ }^{344}$ Others disagreed or asked for more time. ${ }^{\mathrm{x} 3} \mathrm{At}$ about noon, though, the House approved the impeachment unanimously, thus endorsing late impeachability-or, at least, deciding that the Senate could sort out the issue. ${ }^{\text {sxo }}$ The House then drafted specific articles of impeachment, approved them, and forwarded the case to the Senate on April 4 ."

Unfortunately for Belknap, 1876 was an election year. The Democrats-who had taken over the House in 1874 due in part to outrage over the Grant administration's scandalous

329. Id.

330. Id. at 167 (summarizing facts in Belknap case).

331. See id. at 167, 171; see also BELkiAa' TRLAL, supra note 18. at 9.

332. BELKNAP TRIAL, supra note 18 , at iii (discussing timing of the restgnation): BUSHNELL, supra note 16 , at 167 (describing Belknap's actions).

333. 4 CONG. REC. 1430 (1876) (statement of Rep. Robbins of North (itrolina).

334. See id. at 1431-32 (statement of Rep. Blackburn).

335. Id. at 1429, 1432-33 (statement of Rep. Kasson) (urging that more une be taken to resolve the issue and citing Justice Stony against late impeachment). An enentual impeachment manager, Representative Hoar, cited Justice Story's statements agamst late impeachment, see infra text accompanying notes 496-501, and argued that the llowe should take its time. 4 CONG. REC. 1431 (1876) (statement of Rep. Hoar).

336. 4 CONG. REC. 1433 (1876) (unanimous approval of resolution of impeachment); $i d$. at 1431 (statement of Rep. Bass) (arguing that it was for the Senate to decide jurisdiction).

337. BELKNAP TRIAL, supra note 18, at ir; Bt SIINEL1.. supra note 16, at $169-70$. 
corruption-were anxious to exploit that corruption again in the 1876 campaign. The Republicans felt pressured to come out strongly against executive corruption as well. ${ }^{3 * 8}$ This explains the lack of even political opposition to late impeachment in the House. Once the case reached the Republican-controlled Senate, however, the motives changed. The vote in the House had been a quick affair, a cost-free way for members of both parties to condemn Belknap and pass the unpleasant constitutional issues to the Senate. But the Senate actually had to try the case. Facing the prospect of a lengthy trial that might dominate the campaign, the Senate first had to decide whether to postpone the case until after the election. ${ }^{3 * 9}$ No Democrat wanted to postpone the case, and most Republicans evidently just wanted to get the case over with; the motion to postpone the case was rejected unanimously. ${ }^{340}$

At this point, Belknap's lawyers moved to dismiss the case for lack of jurisdiction; before reaching the merits, they wanted to litigate the late impeachment issue. "The House managers argued that the impeachment was not late because it occurred on the same day as Belknap's resignation (fractions of a day being disregarded at common law, by their argument), but this theory was never taken very seriously. ${ }^{12}$ In any case, the House from the first had styled the impeachment as being against the "late Secretary of War," for offenses committed "while he was in office." "*3

More than two weeks of wide-ranging arguments on the question of late impeachment ensued, followed by two weeks of senators' reciting their own conclusions." The debate covered virtually every point raised in this Article. Whatever political motivations underlay the final vote, no senator could have

338. See Belknip TRLAL, supra note 18, at 14-15; BuSfinel.t, supra note 16, at 168 (describing political climate in Congress in 1876).

339. See BELKNAP TRIAL, supra note 18, at 11 .

340. Id. at 15 .

341. BELKNAP TRLAL, supra note 18, at 6; BL'SH INELL, supra note 16, at 170-71.

342. See Bel.kNAP TRLAL, supra note 18 , at 6 (raising argument): $a$. at $358-60$ (opinion of Senator Norwood) (rejecting it while voting to convict).

343. Id. at iii, 2.

344. Id. at 15 (beginning of jurisdictional arguments on April 28): al. at 72 (end on May 14): ad. at 77 (beginnung of recitation of opinons on May 15): al. at 158 (end on May 29). 
complained that he had not heard a well-briefed and wellgrounded constitutional argument. ${ }^{\text {st5 }}$

In the end, on May 29, the Senate voted thirty-seven to twentynine that it had jurisdiction over the late impeachment. ${ }^{\text {sto }}$ The majority Republicans-Belknap's party-voted twenty-six to thirteen against, while the Democrats were twenty-four to two in favor. ${ }^{347}$ Some might take this unanimity among Democrats, coupled with significant support among Republicans, as a sign of the case's strength as a precedent in favor of jurisdiction. On the other hand, it might just reflect Democratic partisanship and the pressure some Republicans felt to denounce Belknap. ${ }^{\text {sw }}$

The Blount case is now regarded as settling the issue that only civil officers are susceptible to impeachment. ${ }^{\text {(199 }}$ The House managers and several senators voting in favor of jurisdiction in Belknap's case, however, subscribed to a limited view of Article II, Section 4 and concluded that the only limits inherent in impeachment were those contained in the common-law term "impeachment" itself. ${ }^{5.50}$ To the extent that proponents conceded that Article II, Section 4 does limit impeachment to "officers," they argued that this was a limit on who could commit impeachable offenses and not on when offenders could be tried. ${ }^{351}$

345. Cf. id. at 137 (opinion of Senator Jones of Florida) (-[1.]et us leate to those who shall succeed us the full benefit of even argument which has contributed to the conclusion at which we have arrived.").

At least one partisan observer disagreed in mid-May that the debatte was balanced. The Republican New York Tribune reported: "It seems to be generalls conceded that the managers are no match for the brilliant array of counsel emploved by the deposed secretary, and the general expectation is that the senate will decicle it h.ts no jurisdiction." The Belknap Impeachment Trial, 3 CENT. L.J. 300, 301 (1876).

346. BELKNAP TRLAL, supra note 18, at 76; BUSHNEL., supra note 16. at 176.

347. BUSHNELL, supra note 16 , at 176 (breaking down vote by party lunes). A qut.ss. Republican, Anti-Monopolist Newton Booth, also voted against jurisdiction. Id.

348. See BELKNAP TrLAL, supra note 18, at 124 (opinion of Sentitor Ingalls) (Republican opponent of late impeachment commenting that political parties "alwans embrace among their adherents large numbers of that invaluable class of supporters who invariably study how they can differ with their associates, and never believe they are truk independent unless they act with their adversaries").

349. See supra note 300.

350. E.g., BELKNAP TRIAL, supra note 18, at 34, 49-50 (argument of llowse managers); id. at 80 (opinion of Senator Wallace): id. at 86 (opinton of Senator Sherman); id. at 88 (opinion of Senator Edmunds); id. at 136 (opinton of Sentitor Saulsbury); see also note 167 and accompanying text.

351. E.g., BELKNAP TRIAL, supra note 18, at 34 (angument of House mamagers), wd. it 79 (opinion of Senator Thurman). 
Structural concern about giving the impeachment defendant or the President full power over congressional juriscliction was another popular argument used in favor of jurisdiction. As one senator incredulously stated the counter-argument:

[I]t is gravely insisted that ... it matters not whether the office be vacated by self-amotion, or by judgment of this court, or by executive order . . . The offender is removed, out of office, and cannot be disqualified, cannot be impeached, even though as President of the United States he had committed treason! $!^{332}$

Still others focused on the deterrent effect that late impeachment could have on other officials. ${ }^{353}$

Among those voting against jurisdiction, the most popular argument was that a reading of Article II, Section 4 implied a restriction on the timing of trials in its use of the term "officers" majority's limited reading of this article and section, some opponents also raised the concern that if impeachment were not limited to current civil officers, any private citizen could be subjected to impeachment. ${ }^{350}$ Proponents of late impeachment

352. Id. at 359 (opinion of Senator Norwood); sep also ad. al 78 (opinion of Senturen McDonald); $2 d$. at 79 (opinion of Senator Thurman): w. at 81 (opinion of Senatol Wallace); id. at 90 (opinion of Senator Edmunds): see also supra Part V.D).

353. E.g., BELkNAP TRIAL, supra note 18, at 87 (opinion of Senator Sagent) ("N sentence to disqualification . . operates for the public safety not only by the exclusion of the criminal from office but as a warning and example to all public offices, tenclung to purity in office."); id. at 93 (opinion of Senator Maxey) (stating that clisqualification is inflicted "chiefly, by fearful example, to teach all men that American institutions and the perpetuation of free government, of the people, by the people, and for the people. demand purity in office"); see also supra Part V.A (discussing deterrence).

354. See, e.g., BELKNAP TRLAL, supra note 18, at 29 (argument of defense (ounsel): al at 82 (opinion of Senator Morton): id. at 115 (opinion of Senator Eaton): al. al 126 (opinion of Senator Ingalls); id. at 132 (opinion of Senator Boutwell). Sep also supra Palt IV.B.2 (discussing textual interpretations of constitutional impeachment clauses rasing this argument).

35.5. See, e.g., BELkNAP TRIAL, supra note 18, at 82 (opinion of Senator Mortom): ul at 85 (opinion of Senator Frelinghuysen); id. at 115 (opinion of Semator Eatoul): ul. al 124 (opinion of Senator McMillan). See also supra Part VI.B.2 (discussing textual interpretations of constitutional impeachment clause's raising this argument).

356. E.g., BELKNAP TRIAI, supra note 18, at 26 (argument of defense comsel): al al 127 (opinion of Senator Cameron) ("If the Senate has jurisdiction to try one pivale citizen upon impeachment it has a right to try any private citicen by the samc process."): td. at 100 (opinion of Senator Howe) ("If the first article gives to the llotse the dangerous power to impeach a man because he has once been in office. it gives it the power to impeach him also because he is in danger of getting into office."): 4 . 11 115 (opinion of Senator Eaton); see also supra note 23 and accompanying text. 
naturally disagreed that their view necessitated this implication. ${ }^{357}$

The two sides also tussled over precedents and authorities. Both sides used the records of the Constitutional Convention ${ }^{\text {sis }}$ and the state ratification debates. ${ }^{30}$ Both sides used the Blount case as well. Opponents of late impeachment in the Belknap case argued that the Blount case provided a clear precedent against late impeachment. ${ }^{\text {sto }}$ Proponents retorted that Blount's case stood against only the impeachability of senators and noted that Blount's defense had conceded that resignation could not stop impeachment. ${ }^{361}$ Opponents shot back that such concessions were dicta set forth by counsel who had nothing to lose by narrowing their argument as much as possible. ${ }^{\text {x.: }}$

Justice Joseph Story's commentary provided another prominent source of disagreement. ${ }^{563}$ In his writings, Story had made some statements against late impeachment, which opponents latched onto almost gleefully; ${ }^{\text {tot }}$ this spurred proponents to cite Story's mitigation of his own comments, ${ }^{\text {, as }}$ well as pro-late impeachment comments from others such as William Rawle ${ }^{366}$ and John Quincy Adams. ${ }^{\text {xit }}$

357. E.g., BELKNAP TRIAL, supra note 18, at 34 (argument of House mamlagers).

358. E.g., id. at 38-39 (argument of defense counsel): td. at 53, 57-58 (argument of House managers); id. at 98-99 (opinion of Senator Howe); ad. at 11820 (opmon of Senator Allison); id. at 156 (opinion of Senator Cragin). But ser ud. at 1.45 (opmmon of Senator Booth) (making anti-originalism argument). The contention is discussed in Part III.C.1, supra.

359. E.g., BELKNAP TRIAL, supra note 18, at 120-21 (opinion of Senator Allison): st. at 150 (opinion of Senator Dawes). The ratification debates are discussed in the text accompanying notes 151-58, supra.

360. E.g., BELKNAP TRIAL, supra note 18, at 28 (argument of defense counsel).

361. E.g., id. at 36-37 (argument of House mamagers): see also suprat text accompanying notes 294-95 (quoting concessions at issuc) and 299-300 (discussung actual meaning of Blount precedent).

362. E.g., BELkNAP TRIAL, supra note 18, at 42 (angument of defense counsel): ser also supra text accompanying notes $294-95$ (quoting arguments at issuc).

363. See infra Part VII.A.

364. See, e.g., BeLkNAP TRIAL, supra note 18, at 30, 40, 42 (argumemt of defense counsel); see also supra text accompanying notes $496-501$ (quoting Storv's statements).

365. E.g., BELKNAP TRIAL, supra note 18, at 152 (opinion of Senator Datwes); see also note $\mathbf{5 0 3}$ and accompanying text (quoting Story's caveats and other commentan on Story).

366. E.g., BelkNaP TRIAL, supra note 18, at 111 (opinion of Senator Mhteliell). Rawle is quoted infra in Part VII.A.

367. E.g., BELKNAP TRIAL, supra note 18, at 112 (opinion of Senator Mhtchell). Adams is quoted and discussed, supra, in the text accompanving notes 310-13. Adtams was not a unanimously respected authority. As defense counsel for Belkntap. dismussing Adams's comments on late impeachment. put it: 
With the jurisdictional question out of the way, the trial proceeded for two more months before the final voting began on August $1 .^{368}$ Belknap continued to push the jurisclictional argument, ${ }^{369}$ though, and despite the lengthy and detailed testimony compiled about Belknap's activities, the final decision on the merits reflected the initial decision on jurisdiction. Belknap was acquitted by a thirty-seven to twenty-five vote on the closest charge, five votes away from the forty-two to twenty vote needed for a conviction. Of the twenty-five senators voting to acquit, twenty-two (one Democrat and twenty-one Republicans) indicated that they did so because Belknap had already left office. ${ }^{370}$ Only three senators (all Republicans) indicated that they had gotten to the merits and actually believed Belknap was not guilty of an impeachable offense. ${ }^{571}$ Thus, taking these senators at their word, it seems that Belknap was acquitted only because he was being impeached after he left office.

In sum, the Belknap case provides a precedent that federal officials can be impeached and tried after they have left office. Nevertheless, this precedent is binding only to the extent that the Senate wishes to be bound. ${ }^{372}$ Critics of the Belknap precedent note, correctly, that the minority voting against jurisdiction did not feel bound by the majority, and Bclknap's acquittal was necessarily based on the fact that his was a late impeachment. ${ }^{333}$ On the other hand, after the vote on jurisdiction, the minority failed in an attempt to stop the trial on grounds that a two-thirds vote to convict could not possibly

Mr. Adams of course opposed what everybody else believed 16 be wue. Nothing indeed would have given him greater pleasure than to be unpeached It would have given him an opportunity to come over here and hy dhout hm right and left. His organ of combativeness was always in a state of chome inflammation.

BELKNAP TRIAL, supra note 18 , at 69.

368. See BeLkNAP TRIAl., supra note 18 , at 342 (mentioning the begmning of wotmg)

369. Id. at 170 (Belknap's Answer after defeat on jurisdictional issute).

370. Bi SHNELL, supra note 16, at 186 (describing and tallying vote): ViN I lsst \& FiNkELMAN, supra note 1, at 193 (same).

371. BLSHNELL, supra note 16 , at 186 (describing and tallying vote): Viv lisstl \& FinkELMAN, supra note 1, at 193 (same).

372. See 2 Archbald Tral, supra note 269, at 1653 (senator voting in lawo of late impeachment on basis of Belknap precedent); (ERILARI, supra note 12, “1 (1) (discussing congressional prerogative to revisit constitutional precedents): / $\mathrm{N}(\mathrm{d})$

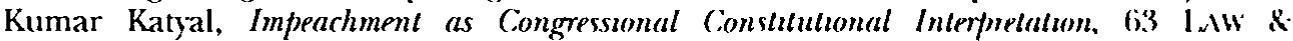
CONTEMP. PROBS. 169, 183-88 (2000) (arguing that rationales for stare dertsu ace not compelling in legislative context).

373. See, e.g., BLSHNELl, supra note 16, at 186-88 (describming umportance of jurisdictional question to senators voting to acquit Belknap). 
result. $^{374}$ In any event, four senators who had voted against jurisdiction nevertheless considered themselves bound by the majority decision - three of them voted to convict. ${ }^{373}$

Furthermore, there is necessarily a difference between an acquittal and a dismissal. The experience of a five-month trial surely had more than just nominal significance to Belknap. ${ }^{\text {sit }}$ His guilt was established, even if he was not subjected to punishment. By deciding only after a full trial to acquit Belknap, the Senate essentially decided that he should not be convicted, not that he could not be. Jurisdiction and conviction are separate questions. The Constitution bars "conviction" with less than a super-majority, but does not similarly bar "trials," and so a simple majority properly decides preliminary matters like procedural rules, jurisdiction, and dismissal. ${ }^{3 m}$

For his part, Chairman of the House managers Scott Lord felt that despite Belknap's acquittal, "great good [would] accrue from the impeachment." ${ }^{\text {"788 }}$ Specifically, Lord felt that "it ha[d] been clearly settled . . . that persons who have held civil office under the United States are impeachable" and that the case had given "the public mind clearer views of official accountability." Manager Hoar agreed and contended that the Belknap impeachment would ensure that no one in Belknap's position would repeat his offenses. ${ }^{\text {s.o }}$ House Judiciary Committee Chairman J. Proctor Knott perhaps put it best when he said:

Was the only purpose of this disqualification simply to preserve the Government from the danger to be apprehended from the single convicted criminal? Very far from it, sir! . . .

374. See BELKNAP TRIAL, supra note 18, at 105-06 (remarks of Senator (hristiand): id. at 76 (vote).

375. Id. at 343 (statement of Senator Booth); id. at 344 (statement of Senator Harvey); id. at 345 (statement of Senator Oglesby); id. at 356 (statement of Senator Morton). In one state late impeachment case, all of the minority of senator who had voted against jurisdiction reached the merits and voted to convict. Ser infra text accompanying note 483 . The state's supreme court eventually resersed the entire proceeding by a narrow vote. See infra Part VI.B.2.d.

376. Cf. DAvies, supra note 54, at 415 (describing ruinous effect of impeachmemt trial on Warren Hastings).

377. See U.S. CONST. art. I, § 3, cl. 6; GeRHARDT, supra note 12, at 35 (duscussing majority requirement for revising rules). The Senate agreed in the impeachment trial of President Clinton that a majority vote (not just one-third plus one) would be required to dismiss the case. S. Res. 16, 106th Cong. (1999).

378. BUSHNEL, supra note 16 , at 188 (quoting lord's statemem in House committee report).

379. Id. (quoting Lord's statement in House committec report).

380. 4 CONG. REC. 5083 (1876) (statement of Rep. Hoar). 
The great object, after all, was that his infamy might be rendered conspicuous, historical, eternal, in order to prevent the occurrence of like offenses in the future. The purpose was . . . to teach [other officials] that if they should fall under like temptations they will fall, like Lucifer, never to rise again. ${ }^{381}$

As a practical matter, if Belknap had presented more of a danger to the Republic-say, if his crime had been more treasonous than venal or if he threatened to serve in the federal government again-the twenty-five senators voting against jurisdiction and conviction might not have stood their ground. Only two needed to change their votes for Belknap to have been convicted, assuming that everyone reaching the merits would have voted to convict in such a case. It also appears that some senators were swayed by the fact that Belknap faced criminal liability that might result in a sentence of disqualification. ${ }^{1 \times 2}$ It is impossible to know for sure, but if 1876 were not an election year, if the partisan balance in the Senate had been different, if resignation had come after impeachment rather than hours before, or if other facts that lack constitutional significance had been changed, the Senate easily could have reached a different result. ${ }^{3 \times 3}$ More to the point of this Article, even if the weakness of the majority in favor of late impeachment in the Belknap case prevented Belknap's conviction, it did not prevent his impeachment and trial, and it certainly does not legally bar future late impeachments.

\section{Archbald}

Judge Robert Archbald was impeached and convicted in 1912 for corruption. ${ }^{384}$ At the time of the impeachment, Archbald sal on the United States Commerce Court as a circuit judge, but six of the twelve specific articles of impeachment covered conduct

381. Turley, supra note 165 , at $54-55$ (quoting Belknap procecedings). Detentenc « discussed in Part V.A, supra.

382. See. e.g., BEl.KNAP TRIAL, supra note 18, at 158 (opinion of Senator ('ragini).

383. Cf. VAN TASSEL \& FINkELMAN, supra note 1 , at 12 ("As a practical matter, the fact that the Senate did not convict Belknap. suggests that except in exuacordinury circumstances, resignation will bring the impeachment process 10 a close."). Practical considerations underlying late impeachment ("should" as opposed to "could") ac discussed in Part VIII, infra.

384. VIN TASSEI \& FINKELMAN, supra note 1, at 132-44 (describing Archbalel ase and listing articles of impeachment). 
he had committed as a district judge. ${ }^{\mathrm{N} s}$ Thus, Archbald's case squarely presents the issue of whether a sitting officer can be impeached for acts perpetrated while holding a former office. ${ }^{\text {wo }}$ If late impeachment is acceptable, then this sort of impeachment should be also. If this sort of impeachment is barred, then so too is late impeachment. ${ }^{\mathrm{s} z}$

Unfortunately, the Archbald case does not provide a definitive precedent. To be sure, the House debated this version of the late impeachment issue. Though Archbald's Answer did not raise it, ${ }^{388}$ both sides briefed it cursorily ${ }^{3,9}$ and argued somewhat more thoroughly at closing, essentially summarizing and recycling the arguments from the Belknap case.

Ultimately, Archbald was acquitted on all of the articles of impeachment that related to conduct in his former office, as well as two of the articles concerning his current post. ${ }^{591}$ The closest vote among the district court articles was thirty-six to twenty-nine against. ${ }^{392}$ Several senators filed written opinions, and many addressed the timing issue. ${ }^{59 s}$ Three senators entertained some doubts about late impeachment and roted to acquit rather than set a precedent that they did not wish to set. ${ }^{3 * 4}$ Six others opposed late impeachment outright. "Five were

\footnotetext{
385. BUSHNELL, supra note 16 , at 219.

386. This issue is covered in more detail in Part Y'.E. supra.

387. This does not mean, conversely, that if Archbald was impeachable for these offenses, then all late impeachments would be acceptable; the fact that Archbald wats a sitting officer might have been determinative. Se supro Part l.E (describing "Whitewater" view that allows impeachment for old offenses, but onlv for stung
} officers).

388. See 1 Archbald Triah supra note 269, at 44-59.

389. See 1 id. at 1062-64 (managers' brief) (anguing that jobs were contumuous): ud. at 1101-04 (defense brief) (surveying some histony of late impeachment and argung against "absurd results" it would entail).

390. See 2 id. at 1412-13, 1424-25, 1470-7l (managers' arguments): 2 ud. at 1505-10. 1545-47 (defense arguments); see also Bl'SHNELL, supra note 16, at 23-4 (mentuonng timing argument by Archbald's counsel).

391. 2 Archbald Trial, supra note 269 , at 1622-46 (chronicling roung on all articles).

392. Id. at 1634 .

393. Id. at 1650-78 (opinions). Some curson opinions were offered dunng the voting. E.g., id. at 1634-36, 1647-48; see also BCSHNEl1., supra note 16, at 233s (sunerung opinions on impeachment after leaving office); Dougherts, supra note 32. 47 2 2.73 (noting opposition to and support for late impeachability in Archbald case).

394. 2 Archbald Trial, supra note 269, at 1634-35 (opinion of Sentator Borah): 2 ud. at 1647 (opinion of Senator du Pont); 2 id. at 1675 (opinion of Senator Simmons).

395. 2 id. at 1635 (opinion of Senator Bnan): 2 id. at 1635-36. 1631 (opmums of Senator Works) (relying on "good behavior" language rather than mpeachment clauses); 2 id. at 1638 (opinion of Senator Brandegece): 2 ud. at $1655-56$ (opmun of 
undecided about late impeachment and abstained as a result." Most significantly, though, seven senators found this particular form of late impeachment appropriate, although three of them voted to acquit on the merits. ${ }^{397}$ Assuming (as we reasonably can) that at least one other senator voting to acquit saw no problem with late impeachment and voted solely on the merits, "' a majority of the senators voting saw no problem with late impeachment. At the very least, though, given that Archbald had already been convicted for other, more recent conduct, this issue "had no real bearing" on the case, as even an opponent of late impeachment has concluded."

\section{English}

Judge George W. English was impeached in 1926 for tyrannical, corrupt, partial, and abusive conduct on the bench. ${ }^{1(1)}$ He resigned six days before his trial was to begin in the Senate." The House resolved that, in light of the resignation, it " $\mathrm{d}[\mathrm{idl}]$ not desire further to urge the articles of impeachment." "The House managers informed the Senate that although they were recommending termination of the proceedings, they were of the opinion that "the resignation of Judge English in no way affects the right of the Senate, sitting as a court of impeachment, to hear and determine" such charges. ${ }^{108}$ Indeed, three senators

Senator Crawford); 2 id. at 1660 (opinion of Senator Mc(iumber); 2 ul. at 1661 (opinuon of Senator Catron).

396. 2 id. at 1621 (statement of Senator (larke): 2 id. at 1632 (statements of Senators Stone and Swanson); 2 id. at 1634 (statement of Senator Smith of (;corgia): 2 id. at 1636 (statements of Senators Newlands and Foster). Stone expressed "grave doubt" about late impeachability, given the "grave abuses" it could spur. 2 ul. at 1652.

397. 2 id. at 1647 (opinion of Senator Owen) (affirming late impeachability, al ledsi with regard to sitting officers); $2 \mathrm{id}$. at 1648 (opinion of Senator Poindexter); 2 ul. al 1650 (opinions of Senators Root and lodge) (affirming late impeachability but voting (1) acquit on merits); 2 id. at 1653 (opinion of Senator Gronma); 2 ul. at 1663 (opinion of Senator (ullom) (affirming late impeachability but voting to acquit on merits): 2 ul. (opinion of Senator Cummins).

398. See, e.g., 2 td. at 1658 (opinion of Senator Oliver, voting apparently solely on the merits).

399. BL'SHNELL, supra note 16, at 238-39.

400. Proceedings of the Unted States Senate in the Trat of Impeachment of Ciemge II English, District Judge of the Inited States for the Eastern District of Illtnows, S. DO(.. No. 69.177. at 3-15 (1926) [hereinafter English Trial] (recording the articles of impeachment).

401. Id. at 76 (mentioning that English's impeachment trial was to begin on November 10, 1926); $\imath d$. at 78 (recording English's resignation on November 1. 1926).

402. Id. at 80-81.

403. STAFF OF HOLSE COMM. ON IHE JUDICHARY, 93D CONC., IMPENCHMVI SElECTED MATERIALS ON PROCEd 891 (Comm. Print 1974) [heinatiel IMPEACHMENT]. 
argued that the resignation should not prevent the Senate from passing judgment on English's conduct and punishing him as appropriate. ${ }^{404}$ Eight others responded that while they agreed that the Senate retained its jurisdiction, they wanted to respect the managers' role as prosecutors and drop the case if the House no longer wanted to pursue it. ${ }^{105}$ As one such senator put it:

The Federal Constitution says that in cases of this kind the House of Representatives shall have the sole power of impeachment .... In view of that language, it seems to me that in this case no choice is left to us. . . but, at the same time, I am sure that I will be allowed the privilege of saying that I deeply regret the conclusion that the House of Representatives has reached. ${ }^{+06}$

No senator suggested that it would have been impossible or unconstitutional to proceed if the House had not "desired" to do otherwise. ${ }^{40 \overline{7}}$ Indeed, one senator noted, without contradiction, that he wanted it "distinctly understood" that the case should not provide a precedent that a resignation would necessarily terminate impeachment proceedings. ${ }^{\text {to }}$ English was old and unlikely ever to serve in federal office again, ${ }^{t(x)}$ and there was little appetite for pursuing what were, after all, mild offenses relative to the effort and resources required to pursue them. The motion to dismiss the case passed seventy to nine."

This case provides another vaguely positive precedent on late impeachability. Clearly, the House and the Senate felt that they could have proceeded with the case. Had the House believed that it had no authority to proceed or that the Senate might reach that conclusion, it would not have passed the carefully worded resolution that it did. If the Senate had so concluded, its debate would have taken on a much different tone.

404. English Triah supra note 400, at 81-85 (speeches of Senators Blease and Dill); $u$. at 89-90 (speech of Senator Wheeler).

405. Id. at 85-89, 90-92 (speeches of Senators Norris, Reed of Penustivama, Reed of Missouri, Bruce, Copeland, King, Fletcher, Borah).

406. Id. at 88 (speech of Senator Bruce). But see ad. at $89-90$ (speech of Sentator Wheeler, arguing that trial could and should continue regardleas of the llouse's decision).

407. But see id. at 91 (speech of Senator King) (alluding to Delahav case and suggesting that resignation was treated there as "ipso facto terminating the case").

408. Id. at 91-92 (speech of Senator Fletcher).

409. See id. at 92 (speech of Senator Borah).

410. Id. at 92-93 (recording the roll call vote on order of dismissal). 


\section{Aborted Cases}

On numerous occasions, the target of an impeachment inquiry resigned before the House could take a vote." In every one of these cases (except, of course, that of Belknap), the House opted not to proceed. The most famous example of this, of course, is the aborted impeachment of President Nixon. The others, less famous, either concern judges not worth pursuing or more prominent figures against whom the cases were not particularly impressive."

None of these cases contains evidence of a congressional understanding that late impeachment is impossible, but several of the cases spurred debate on the question. For example, Judge Edward Durrell resigned in January 1875 after the House Judiciary Committee passed an impeachment resolution against him. ${ }^{113}$ The House discontinued the proceedings by a 128-69 vote after a discussion on whether the House had any power to proceed." Representative Benjamin Butler, who favored impeachment, argued after the resignation that impeachment could proceed but should not, given Durrell's advanced age.": Representative Luke Poland opposed impeachment on the merits but did not believe that resignation presented any sort of obstacle to the House proceeding, if it so chose." Representative Lyman Tremain, who also opposed impeachment on the merits, expressed "serious doubt" as to the House's power to proceed. ${ }^{117}$ Given that the only people who spoke in favor of the power of late impeachment opposed it on the merits in Durrell's case, the House's vote here does not represent any sort of statement against the constitutional power of late impeachment. Similar statements were made in favor of

411. BCSHNELL, supra note 16 , at 39 ("More than fifty federal judges have resigned while under investigation or after their impeachment had been recommended to the House of Representatives, and further action was not pursued against them.").

412. See INPEACHNENT, supra note 403, at 691-92 (Judge Stephens); ul. at 710 (Judge Irwin); id. at 720-22 (Judge Durrell); $2 d$. at 726-28 (Judge Busteed); ud. at 85.3-56 (Juclge Hanford); id. at 859-61 (Justice Wright); id. at 880-81 (Secretary Mellon).

413. Id. at 720 .

414. Id. at 720-22; see also 3 CONG. REC. 319-24 (1875) (recording debate and vote).

415. 3 CONG. REC. 320 (1875).

416. Id. at $322-23$.

417. Id. at $320-22$. 
the power of late impeachment in other cases in which the merits did not warrant proceeding. ${ }^{\text {t1 }}$

It is undeniable that this series of cases indicates that late impeachment rarely will be deemed worthwhile. On the other hand, it does not indicate that Congress is powerless to proceed in such cases. By analogy, the vast majority of criminal prosecutions in this country end in guilty pleas, with no trial and with reduced sentences but at a tremendous savings of resources on the part of the prosecution and the courts. Given how timeconsuming and distracting full-blown impeachment proceedings tend to be, it is no surprise that late impeachment is typically considered not worth the effort.

Just as the reality of frequent plea bargains in the mass of minor criminal cases (and the occasional big one) does not affect the prosecution's ability to go to trial if necessary, the reality of impeachment practice does not change the potential for late impeachment. Congress, moreover, does not blithely concede its jurisdiction. The biggest limitation that the Senate has allowed to its jurisdiction came in the Blount case, in which it was decided that senators were not impeachable. But the Senate's decision (notably, against the House's conclusion), while constitutionally defensible, shows a sort of self-interest that would not necessarily duplicate itself in the impeachment of a former executive or judicial officer. ${ }^{-19}$

\section{B. State Impeachment After 1787}

After 1787, the states continued to provide instructive examples both for and against late impeachment. Because the language of the federal Constitution was already set, state precedents based on dissimilar state constitutional language represent less persuasive authority. To the extent that state language did correspond to federal language, the precedents are inconclusive.

\section{Post-1787 Changes to State Constitutions}

In the immediate aftermath of the federal Constitution's adoption, several conventions rewrote their state constitutions,

418. E.g., IMPEACHMENT, supra note 403, at 728 (Judge Bustecd); ad. at 855 (Judge Hanford); id. at 861 (Justice Wright).

419. See supra note 197 . 
including the provisions on impeachment contained therein. In some cases, states adopted specific language from the federal Constitution. Because the impeachment language in Article II, Section 4 of the federal Constitution was so poorly drafted, however, most states adjusted it. ${ }^{120}$

In some cases, it is instructive to see how states with constitutions providing for impeachment before 1787 changed their impeachment provisions after 1787. Other examples are not instructive: Massachusetts and New Hampshire still use their pre-1787 constitutions, while North Carolina did not change its constitution until after the Civil War.

\section{a. Georgia}

Georgia was the first state to adopt a new constitution after 1787. Georgia's earlier constitution had not provided for impeachment at all. ${ }^{421}$ In 1789 , though, the state wrote a new constitution that essentially tracked the federal Constitution, and contained the following impeachment provision: "[The House of Representatives] shall have solely the power to impeach all persons who have been, or may be in office." explicit authorization for late impeachment was reaffirmed in seven subsequent constitutions ${ }^{123}$ and was not removed until the most recent constitutional convention in 1983. Besides providing evidence that late impeachment was well-regarded in 1789, the Georgia provision improves on the form of the federal Constitution in two respects. First, unlike Article II, Section 4, it states directly which people are susceptible to impeachment. Second, it definitively indicates that late impeachment is allowed.

One could argue that by explicitly authorizing late impeachments, the Georgia Constitution meant to distinguish

420. But see, e.g., IND. CONST, of 1816, art. III, $\$ 24$ ("The Governor, and all (avil officers of the State, shall be removed from office, on impeachment for. and convemon of treason, bribery, or other high crimes and misdemeanors.").

421. GA. CONST. of 1777 , art. XLIX (rendering officers "liable to be called to account by the house of assembly" but not providing for impeachment).

422. GA. ConST. of 1789 , art. I, \$9 (emphasis added); see also MEt.viN B. IIIt.., JR., THE Georgla STATE ConstrTttiox 4 (explaining congruence between (ieonglat Constitution of 1789 and federal Constitution).

423. See GA. CoNst. of 1976, art. III, $\$ 6,1$ 1; GA. CoNst. of 1945, art. III. $\$ 6$, I 3 ;

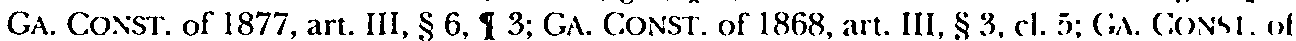
1865 , art. II, $\$ 3$, cl. 4; GA. CONST. of 1861 , art. II, $\$ 3$, cl. 4; GA. CONS1. of 1798, art. I. $\$$ 10. 
itself from the federal Constitution, which, the Georgia framers believed, implicitly disallowed late impeachment. But if this is so, then the specification that the Georgia House has the sole power to impeach officers should be read as a restriction on the federal House's unmodified sole power to impeach, period. In other words, if the wording of the Georgia Constitution of 1789 indicates that the federal Constitution does not allow late impeachment, it also indicates that the federal Constitution allows every private citizen to be impeached. A better interpretation is that Georgia neither added to nor subtracted from the federal impeachment power but changed and/or clarified it.

Georgia removed the "have been in office" late impeachment provision in 1983 because late impeachments seemed irrelevant to the committee charged with redrafting the impeachment section. ${ }^{424}$ The committee's consideration of the issue, preserved in a transcript, is very illuminating as an example of commonsense (if shortsighted) intuitions about late impeachment:

DR. PYLES: May I raise another question? What about this " ... against all persons who shall have been ...." What's the point?

This is highly confusing if you say " . . . shall have been in office . . . ." That's almost ex post facto or something.

MR. CLARK: How can you impeach somebody who's not in office[?]

DR. PYLES: Yeah. Or why. We've got criminal provisions, law, civil law.

MR. CLARK: Any understandable background for that, that phraseology, "shall have been"?

CHAIRMAN SWEENEY: No.

$\cdots$

MR. TIDWELL: If you look further into what you can do, the consequences are, he cannot hold office again. That might shed some light on that.

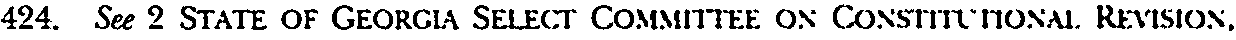
TRANSCRIPT OF MEETINGS, 1977-1981, COMMITTEE TO REVISE ARIT(1.5. 111, Oct. 2 29.1979. at 29-30 (stating subcommittee's understanding that leaving office "obviate[s] the need for an impeachment proceeding"). 
MR. HILL: . . Now a person could leave office and two or three years later something is found out about that person that would be serious enough to warrant an impeachment trial so that he or she could never hold office again.... I don't think the language was happenstance, I think it was intended to cover both people in office and former officeholders.

MR. CLARK: ... [I]mpeachment is to put that person out of office, it seems to me, and the idea if he has committed some malfeasance or violation, that there would be criminal support, this falls into court action rather than the ponderous procedure of an impeachment. I just can't see it ever coming about... it clutters up again and adds questions to the Constitution that is just not necessary.

MS. RYSTROM: I agree with you.

‥

DR. PYLES: I actually think the impeachment provision serves as a deterrent or maybe a threat against an officer, whether it will ever be carried out or not, the fact that it could be carried out is a pretty viable threat it would seem to me to an individual before he continued to persist in whatever it was that would be heinous enough to warrant impeachment.

CHAIRMAN SWEENEY: Especially if he knows that it may come up after he leaves office.

MR CLARK: ... I don't think it's enough-it's not important enough to quibble about. I don't think it's likely to come up again, so I would be opposed to leaving the wording in there, I don't think it serves any protective purpose at all.

CHAIRMAN SWEENEY: Well, is there a motion to drop it?

.

DR. PYLES: I so move.

CHAIRMAN SWEENEY: All in favor?

MS. RYSTROM: I was getting convinced on the other side as this discussion went on.

CHAIRMAN SWEENEY: Four [out of seven committer members present] in favor of dropping the language. ${ }^{12}$

The Georgia late impeachment language, which had survived seven constitutional revisions, did not survive the eighth. The subcommittee started somewhat confusedly: How would late impeachment be "ex post facto"? Why does the availability of the criminal law preclude late impeachment but not regular

425. 1 id., Oct. 1,1979 , at 25-29. 
impeachment? Nonetheless, it eventually covered most of the main arguments about late impeachment. Specifically, the availability of disqualification and deterrence were raised as points in favor of late impeachment, ${ }^{t ; 0}$ while the practical difficulty of late impeachment and the strong connection between impeachment and removal were raised against it. ${ }^{t \prime}$ But the subcommittee ignored the significant potential problem that an official could resign to avoid impeachment and/or disqualification-the situation in many actual cases of late impeachment. ${ }^{428}$

The Georgia experience provides an example of constitutional framers deciding as a practical matter whether late impeachment is worthwhile-something that even proponents of late impeachability admit is a hard point 10 defend. ${ }^{429}$ But this article primarily addresses whether the federal Constitution allows late impeachment, not whether states, writing their constitutions from scratch, should include it. For this reason, the most significant point about the Georgia revision is that when the 1983 framers sought to preclude late impeachment, they used language that reflects the federal language: "The House of Representatives shall have the sole power to vote impeachment charges against any executive or judicial officer of this state or any member of the General Assembly." ${ }^{+30}$ Thus, in Georgia, language setuing forth that only officers can be impeached was meant to preclude late impeachment. ${ }^{431}$ On the other hand, its framers' intent was clear, and the change from the previous language was blunt and meaningful. In the absence of such factors, language like this has been held to allow late impeachment in other states. ${ }^{132}$

426. See supra Parts V.B (discussing disqualification) \& V A (discussing deterrence).

427. See supra text accompanying notes 19-22 (discussing role of removal): mfra Part VIII (discussing practical considerations).

428. See, e.g., supra Part V.A.4 (discussing the Beihnap casc): infra Part VI.B.2.c (discussing the Ferguson case); see also supra Parts Y'.B and I.D (discussmg structural implications of this phenomenon).

429. My own admission of this point, and my response to $1 t$. is detaled in Part Vill, infra.

430. GA. CONST. art. III, $\$ 7,11$.

431. See supra text accompanying note 425 .

432. Examples include the Jones (mfro text accompansing notes 4t5-50), Dovler (infra text accompanying notes 451-52), and Furches (infra note $46-4$ ) cases. 


\section{b. Tracking the Federal Constitution}

Other states changed their pre-1787 constitutions in ways that are significant with regard to late impeachment.

South Carolina wrote a new constitution in 1790. Its old constitution had not mentioned late impeachment. The new one did not either, but its wording matched the federal Constitution's impeachment provisions more closely:

The governor, licutenant governor, and all the civil officers shall be liable to impeachment for any misdemeanor in office; but judgment in such cases shall not extend further than (o) the removal from office, and disqualification to hold any office of honor, trust, or profit, under this state. The party convicted shall nevertheless be liable to indictment, trial, judgement, and punishment, according to law. ${ }^{134}$

While they adopted wording very similar to that in the federal Constitution-and presumably sought to construct a similar impeachment regime-the South Carolina framers joined Georgia's in rejecting the confusing wording of Article II, Section 4. Instead, they specified all of the limitations on impeachment in one section and precisely listed who was "liable to impeachment." The South Carolina Constitution provides some basis for the "late" interpretation of impeachment jurisdiction, as opposed to the "Whitewater" interpretation, in its statements that officers were "liable to impeachment" as opposed to being "liable to removal," and that impeachable offenses had to be committed in office."

Pennsylvania's constitution was the next to be ratified in 1790 . While the old Pennsylvania Constitution had specifically authorized late impeachment if the officer had not left office by the natural expiration of his term, the new constitution was silent on the subject. Instead, it, too, tracked the language of the federal Constitution. ${ }^{135}$ In blurring the issue of late

433. S.C. CONST. of 1790 , art. V. $\$ 3$.

434. The "Whitewater" and other interpretations of impeachment are cliscussed in Parts IV.B.2 and V.E, supra. The dismissal-centered language was used in New Jersey"s revolutionary constitution. Sep supra text accompanying note 75 . Of course, the language in the federal Constitution obscures this point. See supra Part IV.

435. See PA. CONST. of 1790 , art. IV, $\$ 3$ ("The Governor, and all other civil oflic em. under this commonwealth, shall be liable to impeachment for any misdemeanor in office: But judgment, in such cases, shall not extend further than to removal from oflice, and disqualification to hold any office of honour, trust, or profit, under this 
impeachment, the Pennsylvania framers might have intended to expand late impeachment to include those who had left office naturally or to rule out late impeachment altogether. As in South Carolina, though, the failure to mention removal prominently and the use of explicit language regarding the timing of the offense provide some basis for adopting the "late" interpretation of impeachment jurisdiction.

Kentucky joined the Union in 1791 and copied the South Carolina/Pennsylvania language ${ }^{4.60}$ The next year, the framers of the new Delaware Constitution adhered even more closely to the language in the federal Constitution. ${ }^{\text {siz }}$ Recall that Delaware's old constitution had specified an eighteen-month statute of limitations for impeachment cases and had required that the

commonwealth: The party, whether convicted or acquitted, shall nevertheless be lable to indictment, trial, judgment, and punishment, according to law:"). It appears that the 1790 revision initially may not have included the first sentence speesfinng who could be impeached. See MiNUTES OF THE GRAND COMMTTEE OF THE WHOLE CONIENTION OF hH COMMONWEALTH OF PENnSYlvaNia 59 (Philadelphia, Zachariah Poulson 1790) (showng adoption of Article IV, $\S 3$ without its first sentence): id. at 98 (repnntung enture constitution and showing Article IV, $\$ 3$ without its first sentence).

The scope of the new Pennsylvania impeachment clauses was intended to be the sitne as that of the federal provisions-aside from a slight difference in the definuon of impeachable offenses-as demonstrated in a statement by leading Framer and Supreme Court Justice James Wilson: "The president, sice president, and all civil officen of the United States; the governour and all other civil officers under this commonwealth, are liable to impeachment; the officers of the United States, for treason, briben, or other high crimes and misdemeanors; the officers of this commonwealth. for am misdemeanor in office." 1 JAMES W'ILSON, supra note 43 , at 426.

436. See Ky. CONST. of 1791 , art. V, $\$ 2$ ("The Governor and all civil officen shall be liable to impeachment for any misdemeanor in office: but judgment in such cases shall not extend further than to removal from office, and disqualification to hold am office of honor, trust, or profit, under this Commonwealth: but the parts conncted shall nevertheless be liable and subject to indictment, trial, and punishment, according io law."). Tennessee followed suit in 1796. See TENN. CONST. of 1796. art. $\mathrm{N}$. $\$$ \& (-The governor, and all civil officers under this State, shall be liable to impeachment for am misdemeanor in office; but judgment, in such cases, shall not extend further thatn 10 removal from office, and disqualification to hold any office of honor, trust. or profit under this State. The party shall, nevertheless, in all cases be liable to undicument, tmal. judgment, and punishment, according to law.").

437. See DEL CONST. of 1792, art. V, $\$ 2$ ("The Governor, and all other cwil officen under this state, shall be liable to impeachment for treason. briben; or anv high crme or misdemeanor in office. Judgment in such cases shall not extend further than to removal from office, and disqualification to hold any office of honor, trust or profit under this state; but the party convicted shall nevertheless be subject to indiement. tnal. judgment and punishment according to law."): Drat (an of a (osstitition of GOVERNMENT (Wilmington, Peter Brynberg \& Samuct Andrews 1792) (recording identical proposed language circulated to citizenny by order of the consentuon on December 31, 1791); see also PROCEEDINGS OF THE HO' 'SE OF ASSENGBLY OF MIt. DEL_AW ARE STATE 1781-1792 AND OF THE CONSTITUTIONAL CONveNTION OF 1792, a 800 (Claudia $l_{\text {. }}$ Bushman et al. eds., 1988) (recording convention's acceptance of new umpeachment language found in draft cited above); id. at 883 (ratifying same); td. at $36-37$ (describung resemblance between new state constitution and federal (onstitution). 
clock not begin for governors until they left office. ${ }^{\text {ik }}$ Thus, Delaware had required late impeachment for governors and had permitted late impeachment for other officials who left office less than eighteen months after committing their offenses. With the new constitutional language, Delaware no longer required or explicitly authorized late impeachment. On the other hand, it did not forbid them either, and it eliminated the eighteenmonth time limit. In some sense, then, Delaware expanded the impeachment power to include "regular" impeachment; there is no reason to conclude that this expansion was achieved only as an unstated trade for restricting the power of late impeachment.

Vermont rewrote its Constitution in 1793 upon joining the Union. It kept the same language on impeachment, however, and that language remains in the Vermont Constitution today. "' Thus, Vermont is currently one of only two states that explicitly and specifically authorize late impeachment. "') The other statc, New Jersey, added a limited late impeachment power when it wrote its second constitution in 1844, almost as an afterthought."

Finally, Virginia, the first state to address late impeachment explicitly in its constitution, removed that specification in 18.30 . In doing so, it clouded the issue of late impeachment in the same manner as did Pennsylvania and Delaware. Recall that the Virginia Constitution of 1776 had required that governors could only be impeached after leaving office, but placed no time limits on impeachment of other officers. ${ }^{12}$ Requiring late

438. See supra text accompanying note 76 and following discussion.

439. See VT. CoNST. ch. 2, \$58. The Vermont Constitution has been substantulls amended since 1793 , when this provision was found at $\$ 24$.

440. Id. ("Every officer of State, whether judicial or executive, shall be liable io be impeached by the House of Representatives, either when in office ot after Ie'sgnathon of removal for mal-administration.").

441. See N.J. CONST. of 1844, art. V. $\$ 11$ ("The governor and all other officers under this State shall be liable to impeachment for misclemeanor in office, clumg then continuance in office, and for two years thereafter.") (emphasis added); PROC.trDincos of

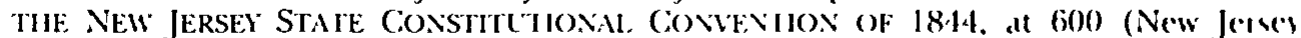
W'riters' Project ed., 1942) (chronicling last-minute addition of late mpeachment provision); see also N.J. CoNST. art. VII, \$ $3, \mathrm{cl} 1$ ("The Governor and all other Stale officers, while in office and for wo years thereafter, shatl be liable to impeachment for misdemeanor committed during their respective continuance in oflice.").

Senator Eaton, an opponent of late impeachment, argued at the Belknap thal that the addition of an explicit late impeachment provision to the New Jersey constitutuon presupposed that the old one-which paralleled the silence in the federal Constitution-barred late impeachment. BEL.K.:IP' TRIAL, supa note 18, at 116.

442. See supra text accompanying note 74 . 
impeachment of governors was a limit, and that limit was removed in $1830 .{ }^{+3}$ Thus, the changes made in 1830 do not answer the question of whether or not late impeachment exists in Virginia.

\section{State Cases}

State impeachment precedents prior to 1787 can enhance an understanding of federal impeachment. These precedents are sympathetic to late impeachment on balance, but the balance is a close one. Moreover, they are decisions by courts, and thus represent a third participant in an inter-branch struggle to define the bounds of impeachment. As with federal cases, though, state cases do not provide a very large sample." They do not readily provide firm conclusions about the nature of late impeachment.

\section{a. Early' Cases}

The New Hampshire case of Judge Woodbury Langdon presents an early state precedent against late impeachment. Langdon resigned from office in 1790 after he had been impeached but before his trial commenced. "The assembly voted not to accept his resignation but had no power to compel him to serve. ${ }^{446}$ When Langdon refused to show up for the trial, the impeachment managers entered a nolle prosequi and the case was dismissed. ${ }^{4 i \pi}$

On the other extreme is Kentucky's impeachment of Thomas Jones, a county surveyor, in $1803 .^{+18}$ Jones resigned during his trial, but the senate decided that this did not remove its jurisdiction over the case. ${ }^{49}$ The trial continued, and Jones was

443. See VA. CONST. of 1830 , art. III, \$ 13 ("The governor, the judges of the court of appeals and superior courts, and all others offending against the state. elther bs maladministration, corruption, neglect of duty, or any other high crime or misdemeanor, shall be impeachable by the house of delegates . . . .").

444. See 1 A.E. DICK HOWARD, COMMENTARIES ON Hit. (ONSIIItIION OF VIRC.NIA 557 (1974) ("Impeachments have been a sometime thing in the states. Nine govenors have been impeached, . . . and impeachment of other executive officen has becn faurly rare. As with the federal impeachment clause, state clatuses have had theor greatest tue in the impeachment of judges.").

445. HOFFER \& HULL, supra note 1, at $126-39$ (describing I ingdon calse).

446. Id. at 128 .

447. Id.

448. See id at 172 (describing Jones case).

449. Id. 
convicted and disqualified from future office. ${ }^{150}$ Similarly, South Carolina impeached Daniel Doyley, a state treasury officer. ${ }^{151} \mathrm{He}$ too was tried despite voluntarily leaving office, was convicted, and was disqualified from future office."

\section{b. Hill}

One distinction between state late impeachments and federal ones is that many state cases have resulted in judicial review. Unlike legislative precedents, judicial precedents carry both a clear statement of intent and understanding (that being the purpose of judicial opinions) and the full weight of stare decisis.

A key case in the realm of state judicial treatment of late impeachment was the Supreme Court of Nebraska's decision in State v. Hill. ${ }^{154}$ Hill rejected late impeachment, against a background of other state cases that had affirmed it." The case concerned the attempted late impeachments in April 1893 of former state officials Thomas Benton and John Hill." Both defendants entered pleas in the state supreme court challenging their amenability to impeachment. ${ }^{137}$ The state constitution provided that "all civil officers of this state shall be liable 10 impeachment for any misdemeanor in office." The court viewed this provision and procedural requirements in the state constitution that related to officers as evidence that private citizens, whether ex-officers or not, were not amenable 10 impeachment:

[S]ection 5, already quoted, designates the persons who may be impeached as "all civil officers of this state." This language

450. Id.

451. Id. at $256-57$ (describing Doyley case).

452. Id.

453. See supra note 163 and accompanying text.

454. 55 N.W. 794 (Neb. 1893). In a case decided the same dav, the cout dismussed another late impeachment on different grounds, while noting its argument in /lill. St.,te v. Leese, 55 N.W. 798, 799 (Neb. 1893) (citing Hill and pointing out that the legislature had no power to impeach Leese because he had been out of office for two ye:aus)

45.5. In each of the cases affirming late impeachment, the defendant was still m office but was being impeached for offenses committed in a previous term. Sep infra note 463 and accompanying text. While this scenario is consistent with late impeachuent, II also consistent with other views of impeachment that preducle late impeachment. So supra Part V.E (discussing this issue with regard to alternative interpretations)

456. Hill, 55 N.W. at 794.

457. Id. at 794-95. The impeachment court in unicameral Nebraskd was and is composed of state judges. NEB. CONST. art. $3, \$ 17 ; H$ Hll, 55 N.W. at 795.

458. Hill, 55 N.W. at 795 (quoting NEB. (ovsı. of 1875 , art. 5. \$ 
is unambiguous. It means existing officers; persons in office at the time they are impeached. Ex-officials are not civil officers within the meaning of the constitution. Jurisdiction to impeach attaches at the time the offense is committed, and continues during the time the offender remains in office, but no longer. ${ }^{459}$

The court also considered a state statute that allowed late trial of impeachment but construed it expressio unius to distinguish between late impeachment (forbidden) and late trial (permitted). ${ }^{460}$

In the process of stating its decision, the court also surveyed Justice Story's commentaries against late impeachment and labeled them a "generally accepted . . . correct exposition of the law." ${ }^{\text {"61 }}$ The court rejected the British cases of Hastings and Melville as irrelevant given the broader scope of English impeachment. ${ }^{462}$ It also considered a trio of state cases (from Nebraska, New York, and Wisconsin) in which a form of late impeachment was approved-officials who served multiple terms continuously were successfully impeached for offenses committed in prior terms. ${ }^{\text {tas }}$ The Hill court distinguished these cases; it considered the current status of the officials more important than the timing of the trial vis-à-vis the offense. ${ }^{k t}$ Finally, it rejected the Belknap precedent because of the weakness of the Senate's majority and also because, unlike Belknap, Benton and Hill were out of office from the natural expiration of their terms. ${ }^{465}$

459. Id. at 796 .

460. See supra text accompanying notes $250-51$.

461. Hill, 55 N.W. at 796; see also infra Part VIl.A (quoting Justice Story's commentary on late impeachment).

462. Hill, 55 N.W. at 797; see also supra text accompanying notes $54-58$.

463. Hill, 55 N.W. at 797. The cases described in Hill, concerning Governor Butler of Nebraska, Judge Barnard of New York, and Judge Hubble of Wisconsin, are deseribed in more detail in Newman v. Strobel, 259 N.Y.S. 402, 406-07 (N.Y. App. Div. 1932).

464. Hill, 55 N.W. at 797. The court did not make clear whether the defendants' terms must be continuous for such an impeachment to occur. though it did mention continuousness in a way that suggests it thought so. See id. The opposite view, howeter. would be more logically consistent-it would focus impeachment on removal for official misconduct, period. This issue is discussed in more detail in Part V.E. supra.

An even starker case-in which senice was continuous but the office changedoccurred after Hill. See 2 Archbald Trial, supra note 269, at 1.424 (mamager's argument) (discussing 1901 case of Judge Furches of North Carolina).

465. Hill, 55 N.W'. at 797; see also supra Part V.A.5 (discussing Belknalp case). Recall that the first state constitution of Pennsyluania and all of the constitutions of Vermom have allowed late impeachment against officials, but onlv if their terms did not exptre naturally. See supra text accompanying notes 78 and 83 . 


\section{c. Ferguson}

Another case, with simpler facts, occurred in Texas in 1924. ${ }^{\text {the }}$ Governor James E. Ferguson had been impeached in 1917 and disqualified from future state office. Ferguson was attempting to get his name on the ballot in 1924, alleging that he resigned the day before he had been disqualified, making the Senate's act void. $^{{ }^{67}}$ As the court described the facts, Ferguson had participated in his trial and had lost the vote of conviction, but "before the Senate, in due course of orderly procedure, could pronounce its judgment, [Ferguson] filed his resignation with the secretary of state."tis The Court rejected Ferguson's argument that he could deprive the Senate of the jurisdiction to sentence him:

[The Senate's] power to conclude the proceedings and enter judgment was not dependent upon the will or act of the Governor. Otherwise, a solemn trial before a high tribunal would be turned into a farce.... [T] he resignation of Governor Ferguson in no manner impaired the power or jurisdiction of the Senate to render judgment . . . ."

To be sure, Ferguson's case was an extreme one. Nevertheless, the Texas Supreme Court recognized that impeachment is not just about removal. The court made clear that if removal were the only possible penalty-if the jurisdiction of the Senate somehow depended on its ability to remove the defendantthen Ferguson's action would have been effective. ${ }^{170}$ Because in Texas, as in the federal system, impeachment convicts can be disqualified, however, this view of jurisdiction must fail. ${ }^{171}$ This was true even though the Texas Constitution, tracking its federal counterpart, referred only to impeachment of the "Governor" (as opposed to the ex-Governor) and made clear that the

466. See'Ferguson v. Maddox, 263 S.W. 888 (Tex. 1924).

467. Id. at 888-89. After losing this case Ferguson simply had his wife. "Ma" Ferguson, run for governor. She won easily and became the nation's second female governor-in part by assuring voters that they would get "two governors for the price of one." because she would follow her husband's advice. Spe John D. I Iuddleston, Fengusm. Miriam Amanda Wallace, THE HANDBOOK OF T'EXAS ONINA., at hitp:// "uww.tsha.utexas.edu/handbook/online/articles/view/FF/ftef.html (last modified July 23. 2001).

468. Ferguson, 263 S.W. at 893.

469. Ser id.

470. Id.

471. Id. 
principal practical purpose of impeachment was to remove sitting civil officers. ${ }^{42}$

\section{d. Smith}

The most recent state opinion on late impeachment is the 1981 Florida decision in Smith v. Brantley: ${ }^{\text {t3s }}$ In that case, the Florida Supreme Court decided four to three that late impeachment was not allowed. ${ }^{7}$

Circuit Judge Samuel Smith voluntarily' suspended himself in 1977, after sixteen years on the bench, in the midst of allegations that he was involved in a scheme to traffic over 1,500 pounds of marijuana. ${ }^{475}$ On January 13, 1978, Smith attempted to resign from the bench, but Governor Reubin Askew refused to accept the resignation, in part because he did not want to prejudice any case against Smith. ${ }^{466}$ The most obvious potential prejudice was the possibility that Smith might not be impeachable if he had already resigned. As expected, on January 31 , a special committee was appointed in the state House to consider impeachment, and on April 12 Smith was impeached."

Smith tried to stop the proceedings with a lawsuit alleging that as an ex-officer he was no longer subject to impeachment." His lawyers argued that he was no longer an "officer," cited numerous cases in which officials who resigned were not pursued, and argued that federal precedent was either neutral or against late impeachment. ${ }^{49}$ The House managers and several

472. Id. at 890 (citing constitutional provisions, including Tt.X. (ONSI. art. XI. \$ 2 (stating that "Governor" and other named officers can be impeached)): ad. $\$$ (allowing legislature to provide for impeachment procedures in cases imsolving "civl officers" not named in $\S 2$ ); id. $\S 5$ (providing for suspension of impeachment defendants from office during pendency of case).

473. 400 So. $2 d 443$ (Fla. 1981).

474. Id.

475. JOURNAL OF THE SENATE, STATE OF FLORIDA 196 (Court of Impeschment 1978) [hereinafter SENATE JOURNAL] (setting forth Article Il of the articles of impeachment: "Conspiracy to Unlawfully Obtain and Distribute in Excess of Approximated 1500 Pounds of Marijuana").

476. See Smith, 400 So. $2 d$ at 445.

477. Id.

478. Id. at $445-46$.

479. Senate JourNal, supra note 475, at 22-23. None of the cases ciled is being dropped upon resignation appear to have involved a determination that 1 would have been unconstitutional to proceed. On the federal precedents. Smith's laturer argued that Blount's case stood against late impeachment, see supra Part VI.A.I. and that Belknap's was not applicable because the majority in favor of late impeachabilits was short of wer thirds, see supra Part VI.A.5. 
senators disagreed and made their own historical and structural arguments. ${ }^{180}$ The Senate voted twenty-nine to six to go forward with the trial after the Chief Justice, presiding over the Senate for the occasion, advised the Senate that it did have jurisdiction over the case even if Smith had resigned. ${ }^{181}$ The trial court then rejected Smith's lawsuit. ${ }^{182}$ The impeachment proceeded, and Smith was unanimously convicted, removed from office (to the extent that the effectiveness of his resignation was in cloubt), and disqualified from future office. ${ }^{18.3}$

Reviewing the case, the supreme court disagreed with its chicf justice and with the lower court. ${ }^{18 t}$ The court concluded that the resignation could be effective despite the governor's refusal $(0)$ accept it, ${ }^{48.5}$ and that once an officer is out of office, the House has no jurisdiction to impeach him. ${ }^{186}$ (Interestingly, because the court was so badly split, Smith's conviction nevertheless was affirmed. ${ }^{487}$ )

The court took a simple view of the question, similar to the one sketched out at the outset of this article. ${ }^{188}$ First, the court looked at the state constitutional provisions that governors, judges, and other officers are liable to impeachment for misdemeanor in office, are to be suspended from performing their duties during the impeachment proceedings, and are to be

480. See SENATE JOL'RNAL, supra note 475, at 26, 31-32 (Court of Impeachment 1978) (recording House managers citing cases of Blount, see supra Part VI.A.1. Belknap. rer supra Part VI.A.5, and Ferguson, see infra Part VI.2.c, and arguing that disqualification, ser infra Part VIII.A, represented adequate basis to proceed against ex-officers); $u$. at 30 (recording inquiry by Senator Dunn that barring late impeachability would allow subject to resign to avoid disqualification, see supra Part V.B, and thereby "unilaterally thwatt the will of the people").

481. SENate JOURNal, supra note 475, at 49 (Court of Impeachment 1978) (vote). id. at 41 (chief justice's opinion). The chief justice relied heavily on the tact that Simuth would receive a pension if not impeached and convicted, which he found to be an adequate basis for proceeding. See infra text accompanying note 506 (smilar angumem in case of President Nixon); Part VIII.B (discussing practical effect of pensions on late impeachment).

482. Smith, 400 So. $2 \mathrm{~d}$ at 446.

483. SENATE JOtRNAL, supra note 475, at $185-87$ (Court of lmpeachment 1978) (mentioning and explaining the votes).

484. Smith, 400 So. 2d at 451 .

485. Id. at 449.

486. Id. at 487 .

487. While the court split four to three on late impeachabilty, one justice wanted of make prospective the ruling that resignations are effective regardless of the governor actions, and so he affirmed the Senate's verdict along with the three dissentess. It. at 15.3 (England, J., concurring in part and dissenting in part).

488. See supra Part II. 
removed from office if convicted. The court concluded that officers are officers; ex-officers, who could not be suspended or removed from office, are not. ${ }^{190}$ The court thus was making the linguistic argument that "officer" meant "sitting officer" and the functional argument that "the primary and dominant purpose of impeachment in Florida is removal of an officeholder from office. ${ }^{\$ 91}$ Once an officer has resigned, this purpose is fulfilled, the court said, and the mere possibility of disqualification from future office does not change the fact that the main purpose of the process has been achieved. ${ }^{492}$ The court considered Blount, Belknap, and Ferguson, but argued that in each case the resignation did not occur until impeachment proceedings had begun. ${ }^{493}$

Three justices dissented, asserting two functional arguments made in this article-that disqualification is significant and that the jurisdiction of an impeachment court should not depend on the whim on the defendant or the timing of his offense:

The majority holding will allow officers who secretly commit serious breaches of the public trust . . to escape impeachment and disqualification if they resign or if their terms of office expire before their misdeeds are discovered and impeachment proceedings are begun. This surely was not intended by the framers of our constitution when they gave the Senate the authority to disqualify . . . ${ }^{194}$

Perhaps fittingly, this closest of constitutional questions received the closest of verdicts.

489. Smith, 400 So. 2 d at 449 (examining FLA. CONST. art. III, \$ 17). In the previous version of the state constitution, disqualification was a mandatonj part of the sentence as well. See id. at 450 (discussing FLA. CONST. of 1885, art. III, \$ 29).

490. Id. at 449-50.

491. Id.

492. Id. at 450 .

493. Id. The court was right that Blount and Ferguson left office onls after they had been impeached. See supra text accompanying notes 281-82 (cotering the Bloum chronology) and 466-67 (covering the Ferguson chronology). But Belkmap-who resigned before any official action was taken against him by the House but after his offenses were being considered in committee, se BELLisAP TRLAL, supra note 18, at 130 (opinion of Senator Bayard)-presents serious line-drawing problems that the Florida court glossed over. See supra text accompanying notes 330-32 (discussing the Belknap chronology).

494. Smith, 400 So. 2d at 455 (Alderman, J., concurring in part and dissenting in part). These structural points are discussed supra in Parts V.A (discussing deterrence) and V.B (discussing the significance of disqualification). 


\section{THE COMMENTARY}

Unsurprisingly, given the high stakes and close questions inherent in late impeachment, the issue has attracted its share of commentary from the academy. As with the rest of the evidence marshaled in this article, commentators are divided but lean toward the acceptance of late impeachment.

\section{A. Rawle and Story}

In his famous treatise on constitutional law, William Rawle gave a relatively terse treatment of the issue and concluded that late impeachment was constitutionally acceptable. As he put it, "[I]t is obvious, that the only persons liable to impeachment, are those who are or have been in public office." ""

An even more distinguished commentator, Justice Joseph Story, weighed in on the question a few years later in his Commentaries. ${ }^{196}$ Story disagreed with Rawle, whom he referred to as "[a] learned commentator." Story focused on the prominent mention of removal in Article II, Section 4, which he considered to define who and what was impeachable: ${ }^{118}$

If, then, there must be a judgment of removal from office, it would seem to follow, that the constitution contemplated, that the party was still in office at the time of the impeachment. . . - [T] he language of the constitution may create some doubt, whether it can be pronounced without being coupled with a removal from office. ${ }^{\left({ }^{\prime}\right)}$

Story denigrated disqualification as a remedy, noting that it "would be scarcely felt, as a punishment, by the profligate and the base,", and positing that "it might be argued with some force, that it would be a vain exercise of authority to try a delinquent for an impeachable offence, when the most

495. RAwl.E, supra note 35, at 213 (emphasis added).

496. STORY, supra note 42.

497. 2 id. at 270.

498. Cf. supra note 90 (discussing Story's concession that Artucle II. \$ 1 would fit more logically in Article I).

499. 2 STORY, supra note 42 , at 271 . Story elsewhere mentioned that "[t /here secms to be peculiar propriety, in a republican government at least, in confining the impeaching power to persons holding office." 2 ud. at 256 . In context. howevet. Story was merely limiting impeachment to official as opposed to private action and not discussing the timing of the proceedings. See 2 id.

500.2 id. at 251 . 
important object, for which the remedy was given, was no longer necessary, or attainable. ${ }^{\text {"501 }}$

Although Story's arguments against late impeachment could not convince a majority of the Senate in the Belknap case, he did influence many among the minority. ${ }^{32}$ The main reason that Story's arguments have not received more definitive support is that, with all due respect to Story, his arguments about late impeachment did not address the weakness of the textual case against late impeachment and did not engage, let alone answer, the structural concerns that militate in favor of late impeachability. Story himself seems to have recognized the limits in his presentation; he issued this strong caveat at the end of his discussion of late impeachment:

It is not intended to express any opinion in these commentaries, as to which is the truc exposition of the constitution on the points above stated [including late impeachment]. They are brought before the learned reader, as matters still sub judice, the final decision of which may be reasonably left to the high tribunal, constituting the court of impeachment, when the occasion shall arise.

Opponents of his position have used this caveat, quite rightly, to rebut those who have cited Story as an authority against late impeachment; ${ }^{504}$ Story himself realized that this was not a simple question and that the Senate would have the last word.

\section{B. Recent Commentary'}

More recently, in the wake of Watergate and l'affaire Lewinsky. the argument for late impeachment has reemerged.

The political atmosphere in Watergate was somewhat charged-a President unpopular among law professors, whose conduct seemed clearly to be impeachable, who resigned rather than face impeachment, and who was pardoned by his successor. Other than the dim possibility of state criminal proceedings, the

501. 2 id. at 271 .

502. See supra notes $364-65$ and accompanjing text.

503. 2 STORY, supra note 42, at 273. The hesitam nature of Story's conclusion gave one unblushing adrocate a reason to question whether Ston had written these comments at all. 43 CONG. REC. 324 (1875) (statement of Rep. Butler) ("The dietum of Judge Story upon this question was, I am afraid, like some other diest in his voluminous works, written by some law-school student $\left.[.]^{\prime \prime}\right)$.

504. E.g., supra text accompanying note 365. 
only possibility of punishing Nixon under the law was to impeach him even though he had left office. One article in the Duke Law Journal argued that Nixon could still be impeached," "i: even as it conceded that Congress appeared unlikely to do so. ${ }^{\text {ith. }}$ Another article reached the same conclusion in quite strong terms $^{507}$ and chided Raoul Berger for leaving the late impeachment issue completely out of his book Impeachment: The Constitutional Problems. ${ }^{508}$

It was assumed by some of these same commentators that an impeachment conviction would allow Congress to strip Nixon of his pension, ${ }^{509}$ but it now seems that this would have violated the constitutional limitation on judgments to removal and disqualification. In retrospect, Congress could have taken steps to allow late impeachment to strip an ex-officer of his pension, but it was probably too late to apply such a law to Nixon. ${ }^{110}$

Most recently, Michael Gerhardt, perhaps the leading scholar on impeachment working today, has written that there is a "surprising consensus among commentators" that late impeachment is acceptable. "In fact the consensus, whilc

505. Firmage \& Mangrum, supra note 142, at 1089-94. Firmage and Mangt um noted the Blount concession, see supra text accompanying notes 294-95, the Belknap case, ser supra Part VI.A.5, and the English caveat, see supra text accompanying note 108 . They then argued that late impeachment could be used to disqualify, to strip emoluments, but see infra Part VIII.A, and to set precedent. They recognized, however, that resignation would accomplish many of the goals of an impeachment and so might make It worthwhile to end the proceedings.

506. Firmage \& Mangrum, supra note 142, at 1101.

507. See Bestor, supra note 133, at 277-81 ("[M] any members of Congless. 10 sals nothing of the general public, assume that the liability of an official to impeachment somehow terminates the instant he leaves office . . . Such an assumption has no substantial historical foundation and is not supported by a single authotitative and unequivocal decision of recent times."). Bestor raised the Hastings precedent, see supra text accompanying notes 54-57, the Virginia and Delaware Constitutions, see supra te. $\times 1$ accompanying notes $74 \& 76$, the absence of any constitutional provision bat ring late impeachment, the "whilst in office" discussion at the constitutional convention, sep supro Part III.C.1.b, the Adams quotation, see supra text accompanying notes 310-13. the Belknap case, see supra Part VI.A.5, and the functional argument that late impeachment would be less destabilizing than seeking to remove a sitting President. see infma text accompanying note 543 .

508. See Bestor, supra note 133, at 280-81 (arguing that late impeachment is a more important problem than others considered at length by Berger).

509. Firmage \& Mangrum, supra note 142, at 1092.

510. See infra Part VIII.B (discussing ability to use impeachment to strip pensions).

511. GERI IARDT, supra note 12 , at $79 \&$ n.22 (citing as examples an earlier article by himself; Rotunda, supra note 190; Firmage and Mangrum, supra note 142; and Bestor. supra note 133). Others have written in favor of late impeachability. Lig.. Jonathan Turley, The Executive Function Theory, the Hamilton Affair, and other Constututumal Mythologies, 77 N.C. L. REv. 1791, 1827 (1999) (“[T] he Belknap case indicates that 
surprising, is not unanimous..$^{512}$ ) Gerhardt agrees that the precedents of failure to use late impeachment reflect practical considerations rather than constitutional limits." Gerhardt cites the Warren Hastings precedent and pre-1787 state constitutional language addressing late impeachment. ${ }^{514} \mathrm{He}$ continues with a structural argument about disqualification, evidence of original understanding, citation to John Quincy Adams, and a dismissal of Justice Story's concerns. ${ }^{515}$

When President Clinton outraged many with his literally lastminute pardons, the issue emerged again. I can personally relate that I wrote an updated op-ed piece on the subject, which was rejected by all outlets to which I submitted it, including one conservative publication that said the notion of impeaching a President after he had left office was too fantastical even for them. ${ }^{516}$ A few days later, Senator Arlen Specter appeared on a Sunday morning talk show and expressed his favorable opinion on late impeachability, which suddenly seemed much less fantastical, if still quite unlikely in Clinton's particular case." Specter's comments in favor spurred commentary of its own on both sides of the issue, thus further belying the consensus that Gerhardt had found not long before. ${ }^{\text {sli }}$

resignation from office does not prevent trial on aricles of impeachment."): (..S. Pots, Impeachment as a Remed), 12 ST. LOUIS L. REv. 15, 23 (1927).

512. See supra note 16 (listing some of those who have written against late impeachability).

513. GERHARDT, supra note 12, at 79-80 ("No doubt, there are numerous reabons not to move for impeachment against an official after resignation, but none of these atre constitutionally mandated."); see infra Part VII.

514. GERHARDT, supra note 12, at 79. On Hastings, see supra text accompanying notes 54-57. State constitutional language is discussed in Part III.B.2, supra.

515. GERHARDT, supra note 12, at 80-81. On disqualification, see Part V.B. supra. Original understanding is discussed in Part III.C.1, supra, and the "whilst in office" language that Gerhardt focuses on is discussed in Part III.C..l.b. supra. Adims is discussed in text accompanying notes 310-14, supra, and Storv in P'art V'll.A. supra.

516. The piece eventually appeared on the Jurist web site. Sice kilt (J KISI), supra note 8. A similar piece had run two years before-in Cimadia. Ser hilt (Ni1't Posi). supra note 8.

517. See infra text accompanying note 532.

518. See, e.g., Souss, supra note 16 (opposing late impeachabilitv); Mark R. Letun, Arlen Spetter, the Constitution, \& UFOs, NATIONAL REvIEW ONLINE. (Feb. 12. 2001), at http://www.nationalreview.com/contributors/levin021201a.shtml (opposing late impeachability); Kalt (JURIST), supra note 8 (favoring late impeachabilitv): Victor Williams, Pardongate: Another Impeachment After the Investgatsons Conclude?. Finitialls WRT (Feb. 27, 2001), at htt://writ.news.findlaw.com/commentany/20010227_ williams.html (favoring late impeachability). 


\section{PRACTICAL CONSIDERATIONS}

The foregoing has all been directed at the question of whether late impeachment is allowed. It is time to confront a more difficult question for proponents of late impeachment: What is the point?

Even though they do not prove that late impeachment is legally impossible, the nearly unbroken series of cases in which impeachment proceedings were dropped when the target resigned show that pursuing a late impeachment is generally regarded as pointless in actual cases. Whatever the abstract purposes of impeachment, it is evident that removing the target has been the primary practical purpose and that once removal has been accomplished-by whatever means-there was often little point in continuing. Then again, the sample size is fairly small, it includes the late impeachments of Blount and Belknap, and it is easy to imagine a future case in which late impeachment is worthwhile.

\section{A. Disqualification}

Disqualification is currently the only practical consequence to the target of a late impeachment. Despite the many arguments made by proponents of late impeachment that disqualification is a significant punishment, ${ }^{-1 "}$ the simple fact of the matter is that in most cases it is not. Most people who resign to avoid impeachment will carry enough disgrace that they cannot count on being re-appointed and re-confirmed anyway. ${ }^{\text {i2n }}$ Moreover, some of these people have been old enough that they were not likely to get new federal jobs even if they were proven innocent. ${ }^{\text {i21 }}$ Indeed, in most impeachment cases, the Senate has not even bothered to disqualify the convict. ${ }^{j 22}$

Still, one can imagine a case in which disqualification is worthwhile. An official may have committed an offense so heinous that it is appropriate to declare to the nation that he is constitutionally unworthy of "honor, trust, or profit."

519. See supra Part V.B.

520. Cf. supra note 269 and accompanying text.

521. See, e.g., supra text accompanying notes 408-10.

522. Of the fourteen men convicted in impeachment cases, only two. Judges West Humphreys and Robert Archbald, have been disqualified. BistiNeLt, supra note 16 , at 6 . 
One can also imagine a case in which the prospect of the convicted party staging a comeback is likely enough-and undesirable enough - that disqualification is worth pursuing. While the undesirability of such a comeback is a subjective matter that would depend on the specifics of the case, there is little doubt of their likelihood. Senator Blount remained popular at home and could have staged a comeback if he had not died prematurely. ${ }^{\text {jes }}$ President Andrew Johnson was elected to the Senate after he left office. ${ }^{\text {ind }}$ Belknap had a successful Washington law practice after his impeachment." One can easily imagine a relatively young ex-President such as Bill Clinton being interested in a judicial or diplomatic post. There is, of course, a potential for abuse in such a situation, similar to Hypothetical 1 at the beginning of this article disqualification might be used as a weapon to defealt the political will of a convict's supporters. This is a problem inherent in impeachment itself, however, and not just late impeachment in particular.

A further advantage of late impeachment is that the punishment is much more flexible. Especially when highranking executive officials are tried, remoral from office is so weighty and disruptive a penalty that it might preclude adjudication of the impeachment case "on the record." Disqualification is a severe penalty, but it is not mandatory; it is just the maximum. ${ }^{528}$ A late impeachment could result in a suspension of eligibility for certain offices, or for a certain time, or it might result in no punishment at all."

To be sure, if Congress were interested in expressing its disapproval of an ex-officer without actually leveling

523. See id. at 37.

524. See BUSHNELL, supra note 16 , at 160 (describing johmson's post-ptestedental career); Lawrence Kestenbaum, Johnson, Andral (1SOS-1575), in IH1 PO1111C.11 GRAVEYARD, at http://www.politicalgraveyard.com bio. johnsonl.hunl (list modified May 13, 2001).

525. See BuShNeLL, supra note 16 , at 189.

526. See supra text accompanting note 1: see also supra note 396 (disctusung argument of Senator Stone).

527. See infra text accompanying note 543 .

528. While precedent establishes otherwise, some believe that disqualtficatuon as mandatory. See supra note 165.

529. See BELkNAP TRLAL, supra note 18 , at 48 (argumem of House managen m late impeachment trial). 
punishment, it could simply censure him. ${ }^{530}$ But this provides a perfect example of the special essence of impeachment. Censure reflects the desire of a bare majority of Congress to make a relatively costless-and weightless-political statement. Impeachment, by contrast, requires a two-thirds majority in the Senate, which essentially requires bipartisan agreement. The very difficulty of obtaining an impeachment conviction casts it as a sober and momentous judgment rather than just a cynical political one. If the Senate determines that punishment is not worthwhile in the case at hand, this reflects its nuanced judgment rather than the inevitable limits of the mechanism itself. Moreover, because of its inherent weight, impeachment represents a determination that similar conduct by others in the future is liable to be held impeachable and, if the target is in office, basis for mandatory removal. An impeachment of one person thus represents a precedent for others, promoting accountability and providing deterrent. By comparison, censure is just congressional froth, as significant as a joint resolution commemorating National Toothpick Week. "31

In any case, just as disqualification is available as a remedy even though it is rarely necessary, so too is late impeachment available regardless of how infrequently it proves worthwhile.

\section{B. Punishment Beyond Disqualification}

A practical reason to pursue late impeachment is that disqualification may not be the only punishment facing the officer in question. When Senator Arlen Specter suggested in February, 2001 that former President Clinton could still be

530. The constitutionality of censure is a matter of some disagreement, most recenth during the Clinton impeachment. See Michael J. Klarman, Constilutuonal liptushusm and the (\%mton Impeachment Debate, 85 V.1. 1. ReV. 631.649-50 \& mm.73-74 (1999) (citmg differing opinions on censure during (Clinton impeachment). The argument in favon of the constututionality of censure is more persuasive. See, e.g., Michacl J. (ierhade, The Constututhonaluty of Censure, 33 L'. RICH. L. RFS. 33 (1999) (presenting basic agument in faror of constitutionality of censure).

531. Is an example. President Jackson's censure by the Senate an 18.34 was expunged three vears later when his party took control of the Senate. 13 (.oN(. D) B. 50). (1837) (resolutuon expungung Jackson's censure); Jack (haney. The Constuluthonalty of (imsumng the Presudent, 61 Orio Sr. L.J. 979, 981-82 (2000) (describing eprsode). II cemsure actually carried any weight, it would be more likely to be unconstitutional pursuant to the constitutional prohibition against bills of attainder. Compare James (: Io. . Musunderstood Precedent: Andrew Jackson and the Real Case Agamst Cemsure, 24 HhkV. J I. \& P( B. PO) $Y 283.290(2000)$ (arguing that censure violdtes prohibition on attainder). whth (ierhardt. supra note 530. at 34 (arguing that Congress has the athority to "pass a non-binding resolution expressing an opinion" such as censure). 
impeached, he did not even mention the possibility of disqualifying Clinton from future office. Instead, Specter indicated that if convicted, the ex-President would lose his perquisites:

President Clinton technically could still be impeached. And you say how can that happen, he's out of office: Because a president may be impeached for the emoluments of office. such as the substantial sums being spent on the library, such as the bodyguards, such as his pension. ${ }^{\text {s.s. }}$

Although Specter was correct (if lonely) in asserting that Clinton could still be impeached, he was wrong to state that Clinton's punishment upon conviction could include stripping him of his "emoluments." Federal law currently provides that a President who is impeached does lose his pension and other benefits, but only if he is impeached while in office." Therefore, impeaching Clinton would not affect his emoluments. ${ }^{534}$

All of this means that if a malfeasing President is interested in keeping his pension, he need only wait until the end of his term to commit his impeachable offenses. To avoid this sort of misincentive, ${ }^{535}$ Congress should change the law to make clearprospectively-that an impeached and convicted President (or other official) does not deserve to reap millions in federal benefits, regardless of when the offenses and impeachment occur. This would add teeth to late impeachment and make it much more likely to be a worthwhile exercise of congressional resources. It would also prevent the awkward situation of Congress using a pension as an improper bargaining chip to induce resignation. ${ }^{536}$

532. Fox News Sunday (Fox News Channel television broadc dst, Feb. 11, 2(1)1, (transcript available at 2001 WL 7790809); see also text accompanumg note i)! (expressing similar belief by Watergate-era commentators).

533. 3 U.S.C. $\$ 102$ (1994) ("As used in this section, the icrm 'fotmer Prendent" means a person . . . whose service in such office shall have termundted other that bo removal pursuant to section 4 of article Il of the Constitution of the linted Stutes of America[.]").

534. Changing the law just to reach Clinton might have constututed an unconstitutional bill of attainder. If it would not have been an attunder, (emgrems could have passed a law stripping Clinton of his benefits without bothenng to go through the cumbersome impeachment process.

535. See infra Part VIII.D.

536. Congress apparenty continued the impeachment proceedings aganust Judge Warren Davis even after he had resigned from office, until he agreed to guc up hus pension. See Turley, supra note 165 , at 75 n..359. 
One could argue that making the punishment on conviction include such a severe financial penalty would violate the constitutional provision that "Judgment in Caases of Impeachment shall not extend further than to removal from Office, and disqualification to hold and enjoy any Office of honor, Trust or Profit under the United States." however, it makes the current presidential benefits law unconstitutional as well. More to the point, the law defining the benefits of ex-Presidents operates independently of the impeachment process-it is a law approved by both houses and the President, and losing the pension would be based on the operation of the pension law, not on the "judgment" of the Senate in the impeachment case. ${ }^{\text {is }}$

\section{Precedent}

As in the rest of our common-law system, impeachment cases not only affect the principals of the immediate controversy, but also establish the principles that future cases will follow. An impeachment case may present issues on which Congress wishes to establish precedents, and late impeachment may be the only way to do this successfully.

Hypothetical 3 presents an example of a potential case in this vein. $^{* \cdots}$ If the issue is whether a certain type of conduct is impeachable, regardless of its criminal nature, there is no substitute for impeachment to develop the precedent. Impeachment convictions and acquittals are rare, but they do serve to telegraph to other officials which conduct will, or will not, be tolerated. If Congress feels the need to resolve an issuc by setting such a precedent, it might wish to proceed even if the target is no longer in office.

\section{Timing}

Another reason that a late impeachment would be appropriate is timing. Ideally, holding all other things equal, an offense committed near the end of an officer's tenure would be

537. L'.S. Const. art. I. \$ 3, cl. 7.

538. One could respond that the lucrative post of ex-President is, in a sense, all "office" of "profit," from which removal and disqualificaton is acceptable, but his secrm too cute. (f. Kalt, supra note 13, at 797 (using disqualitication language in doreussung congressional power to provide for ex-Presidents).

539. See supra text accompanying note 3. 
treated the same as one occurring at the beginning. At the beginning of a presidential term, if the President or a cabinet member commits an impeachable offense, he can be impeached, removed, disqualified, and prosecuted. At the end of the term, given the cumbersome nature of the impeachment process, he can only be prosecuted.

To be sure, this difference may just boil down to the value of disqualification, and as argued above disqualification often will not be enough to warrant proceeding with a late impeachment. ${ }^{5+0}$ On the other hand, the fact that disqualification usually will not matter does not justify taking it off the table for the cases in which it would matter. And if stripping the President of millions of dollars worth of benefits is added to the $\mathrm{mix},{ }^{5+1}$ the incentive effect would easily be significant enough. Moreover, criminal prosecution is rarely if ever certain in the sorts of cases that lead to impeachments."

One might also argue that, for Presidents anyway, late impeachment is preferable to "regular" impeachment precisely because it does not involve removal. Thus, it is the "least disruptive way" to adjudicate presidential misconduct, and it ensures that external factors will not unduly sway the sober judgment of the Senate. . $^{\text {s. }}$

Without late impeachability, then, lame-duck officials are situated in a way that allows them to perpetrate offenses against the United States with relative impunity. Any disincentives to such conduct that can be erected would improve this situation, and late impeachment is an obvious way to do just that.

\section{E. Congress Defends Its Turf}

The structural problems that late impeachment helps to avoid have already been described. ${ }^{5+4}$ Congress might find itself in a case where an executive or judicial official is thumbing his nose

540. See supra Part VIII.A.

541. See supra Part VIII.B.

542. See supra note 235.

543. See Bestor, supra note 133, at 281 ("The removal of the actual hesd of state, however, is potentially so threatening to the stability of government isself. that public opinion is usually prepared to allow precedents of executive usturpation to accumulate rather than run the risks involved in impeachment. Such risks, howeser. disilppear if a President is made to answer for willful violations of the supreme law after he has ceabed to be in office.").

544. See supra Part V. 
at his would-be impeachers. If Congress is interested in preserving its role in government oversight, it would have to take action through late impeachment. If an official's resignation amounts to something of a guilty plea and achieves removal without the expense and distraction of an impeachment trial, Congress would have no reason to proceed just to protect its turf. If, by contrast, the resignation is calculated to avoid disqualification, maintain a pension, or preempt public inquiry, ${ }^{5}$ then Congress will want to assert itself. Thumbing one's nose at Congress (as the President does in Hypothetical $4^{5.65}$ ) would be-and should be-a surefire way to spur Congress to pursue a late impeachment."

\section{F. Quick and Easy}

One objection to late impeachment is actually a reason in its favor. Given how cumbersome the impeachment process is, critics ask, why bother impeaching an ex-officer when the criminal justice system will probably handle the case itself? If an official is in office, impeachment is necessary to remove him even if he is convicted of a crime. ${ }^{\text {its }}$ Once he is out of office. though, removal is irrelevant, and the punishments that a judicial court can dole out may represent adequate punishment. Indeed, the punishment for violating the federal bribery statute can include disqualification (though this provision would $\mathrm{secm}$ to be of dubious constitutionality).

545. Congress can still hold hearings and launch investigations without holding fullblown impeachment proceedings. However, the impeachment process can be stated bs anyone. Regular hearings, by contrast, require as a practical matter that a committe chairman be interested in pursuing the matter. Depending on the party and power alignments in Congress, impeachment may be the only way to brung the (ase to the forefront. See supra Part V.D (discussing role of mpeachment in light of congtessonil power to launch lesser investigations).

546. See supra text accompanying note 4.

547. Cf. BELKNAP TRLAL, supra note 18, at 87 (opinion of Senator Sherman) ("It is not likely that the power to impeach persons not in office, for official musconduct when in office, will often be invoked, and only in extreme cases and when the offender flees from justice by resignation.").

548. A striking example of this fact occurred in 1986, when Judge Hanry (ilabone was convicted of tax evasion. Claiborne was sentenced to prison, where he sit recevilug his judicial salary, apparently intending to retake his seat on the bench when hu sentence expired. Bt'SHNELL, supra note 16 , at 289 . This moved the Iouse 10 mpeat h him. Id. at 293. This spectacle recurred three years later in the case of Judge Walte' Nixon, who refused to resign despite being umprisoned. Nixon $x$. United States. jo6 (1.S 224, 227 (1993).

549. E.g., 18 U.S.C. $\$ 201$ (b) (1994) (specifying that person convicted under butbes provision "may be disqualified from holding any office of honor, trust, on profit unde- 
On the other hand, if a person is out of office and is being pursued by the criminal justice apparatus, there is much less reason not to impeach him-after the criminal process has run its course. Because the impeachment is "late" already, there would be little pressure to conclude the impeachment quickly. Congress can simply wait for the criminal case to conclude and, if guilt is obvious, use the record developed by the court to perform an expedited impeachment and trial. ${ }^{5.00}$ For this reason, if the pragmatic decision on whether or not to launch a late impeachment is based on a cost-benefit analysis, the "cost" may be much less than that of a regular impeachment.

\section{G. Potential Abuse}

As a final note, one might argue that giving Congress the ability to impeach ex-officers introduces a dangerous potential for abuse. The impeachment power is one of the few held by Congress that carries with it no inter-branch check or balance. From its early near-abuse by Jeffersonians in the early 1800 s to its highly politicized use against Presidents Johnson and Clinton, this dangerous potential of impeachment has often been at the forefront of debate.

While as a practical matter, late impeachment may be susceptible to abuse, it is, however, subject to the same safeguard that has prevented abuse of regular impeachment-the fact that

the United States"); id. $\$ 1901$ (covering disbursing officers trading in public property). Similar provisions date back to the First Congress. See Act of Apr. 30, 1790, ch. 9. $\$ 21,1$ Stat. 112, 117 ("Act for the Punishment of [C]ertain Crimes [A]gainst the L'nited States.").

Notwithstanding this fact, the constitutionality of such laws is questionable. -[T]/he Bribery Act of 1790 was never enforced, in part because of concerns about its constitutionality." GERHARDT, supra note 12, at 20. The Constitution would secm to allow the President to appoint and remove whomever he likes, subject only to Senate confirmation in certain cases. Admittedly, though, the courts would probably reject this argument if push came to shove. See United States v. Espy: 145 F.3d 1369, 1372 (D.C. Cir. 1998) ("[W]e have little doubt that Congress could legitimately restrict Agriculture Department officers to those not convicted under the Meat Inspection Act."): see also Myers v. United States, 272 U.S. 52, 128 (1926) (anguing that Congress can prescribe qualifications for offices, so long as "the qualifications do not so limit selection and so trench upon executive choice as to be in effect legislative designation").

550. Congress proceeded quickly, if not as quickly as it could have, in the casses of Judges Walter Nixon and Harry Claiborne, both of whom had already been convieted of crimes when they were impeached. See Nixon, 506 U.S. at 297-28 (describing Nixon trial, which entailed four days of hearings and three hours of floor debate): BL'SiNid. supra note 16, at 293-301 (describing Claiborne trial, which entailed seven dans of hearings and three days of Senate deliberation); of. GERHARDT, supra note 12, it 45 (noting that despite "ample discovery" in criminal trials, Nixon case entailed substantial pretrial workload). 
conviction is designed to be difficult to achieve. "Indeed, the Jeffersonian Republicans failed to convict Justice Chase and the rest of The Federalist judiciary; the Radical Republicans failed to convict President Johnson; and the latter-day Republicans failed to convict President Clinton. The reasons are many, but most can be tied back to the original design of impeachment. Trial is placed in the Senate because it is designed to be a deliberative and relatively careful body. for conviction in order to require that an impeachment conviction cannot occur without bipartisan support or, in the unusual event that one party has a two-thirds majority in the Senate, without unusual party unity. In any case, the impeachers and triers are accountable to the voters. These structural safeguards are adequate for regular impeachment, and they are just as adequate for late impeachment.

\section{H. Conclusion}

While late impeachment is usually not worth pursuing, this Part of the Article has sketched out some reasons why it may be in future cases. The punishments available-disqualification and possibly others-may prove compelling. The case may present a unique opportunity to set a precedent or a good way to make an example of a lame duck offender. If the officer's affront 10 congressional power is too great, late impeachment provides a structured and restrained method of defending Congress's honor. Finally, the costs would be lower and the potential for abuse no higher than with regular impeachment.

\section{CONCLISION}

Late impeachment provides a difficult problem of constitutional interpretation. It confronts an ambiguous portion of the text, which renders unclear whether the political focus of impeachment limits just the offenses and offenders who can be pursued or whether it also restricts the timing of the proceedings as well. But if the text is unclear, the history underlying it is not. Late impeachment was practiced in England and, unlike other aspects of English impeachment, was never

551. See BELK\AP TRIAL, supru note 18, at 94 (opinion of Senator W'right) (makmg similar structural point about abuse); $u$. at 112 (opinion of Senator Mitchell) (s.tme).

552. TuE FEDERILISI No. 65, at 397.98 (Alexander Hamilton) (Cilinton Rossiter ed.. $1961)$. 
explicitly ruled out in America, either in pre-1787 state constitutions or in the federal one. Indeed, some state constitutions made late impeachability explicit or even required.

Constitutional structure is also consistent with late impeachability. If the only purpose for impeachment were removal, then there would be no reason to conduct a late impeachment. But removal is not the only purpose of impeachment. Impeachment is designed as a deterrent to prevent offenses from occurring in the first place, and this deterrent effect would be severely undermined if it faded away near the end of a term. Moreover, convicted impeachees can be disqualified from future federal office, an important punishment that the offender himself should not be able to moot. Nor should the President be able to preempt a full investigation or full punishment; the Constitution forbids the President from using his pardon power to achieve these ends, and late impeachment is the only way to prevent an end run around this clear structural imperative. Although some opponents of late impeachment make allowances for these extreme cases by allowing some late impeachments, in reality, no constitutional basis exists for distinguishing between them.

Finally, precedent favors late impeachability. Admittedly, there is no wholly clear and binding authority. States construing similar provisions have come to mixed results. But the Senate, which, in the end, is the final arbiter of this question, has approved late impeachment. Senate opponents of late impeachment may have prevented convictions, but they have not prevented late trials, and they cannot alter the formal declaration of a majority of the Senate that officers can be impeached after they have left office.

In practice, late impeachment may rarely if ever prove worthwhile to pursue. Then again, one can imagine several scenarios in which it might. Even if no occasion ever arises in which late impeachment is worthwhile to pursue, this would place late impeachment in the same class as regular impeachment-more important to have available than to actually use. No federal executive official has ever been impeached and convicted, either while in office or after leaving it, but every federal officer is appropriately constrained by the possibility of impeachment, and it is only with late impeachment that this constraint can be properly whole. 
Heinonline -- 6 Tex. Rev. L. \& Pol. 136 2001-2002 